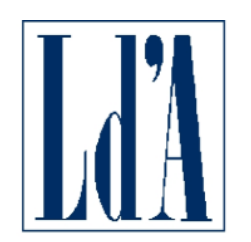

CENTRO STUDI LUCA D'AGLIANO

WWW.DAGLIANO.UNIMI.IT

CENTRO STUDI LUCA D'AGLIANO

DEVELOPMENT STUDIES WORKING PAPERS

N. 409

November 2016

Social networks and the intention to migrate

Miriam Manchin*

Sultan Orazbayev*

* University College London 


\title{
Social networks and the intention to migrate*
}

\author{
Miriam Manchin $^{\dagger} \quad$ Sultan Orazbayev ${ }^{\dagger}$
}

November 29, 2016

\begin{abstract}
Using a large survey spanning several years and more than 150 countries, we examine the importance of social networks in influencing individuals' intention to migrate domestically or internationally. We distinguish close social networks (composed of friends and family) and broad social networks (composed of same-country residents with intention to migrate), both at home and abroad. We find that social networks abroad are important driving forces of migration intentions, more important than work-related aspects or income. In addition, we find that close social networks abroad with remittances matter significantly more than those without remittances as the individuals become more educated, indicating that networks might work through different channels for individuals with different level of education. On other hand, we find that having stronger close social networks at home reduces the likelihood of migration intentions.
\end{abstract}

Keywords: intention to migrate, social networks, local migration, international migration, remittances.

JEL codes: F22, F24, R23, O15.

\footnotetext{
${ }^{*}$ This paper draws on a previous mimeo: Miriam Manchin, Robert Manchin, Sultan Orazbayev (2014) "Desire to Migrate Internationally and Locally and the Importance of Satisfaction with Amenities". The authors would like to thank Chris Gerry, Femke de Keulenaer, Anna Maria Mayda, Mariapia Mendola, Doug Nelson, Dragos Radu, Hillel Rapoport, participants at "Global Challenges" workshop in Milan and Galbino workshop, conference participants at EEA 2015, ETSG 2015, The Changing Face of Global Mobility 2016, and seminar participants at Nazarbayev University, Tubingen University and UCL (SSEES) for helpful comments and suggestions.

${ }^{\dagger}$ University College London: m.manchin@ucl.ac.uk, s.orazbayev@ucl.ac.uk.
} 


\section{Introduction}

Social networks in the migrant's destination have been shown empirically to be important drivers of international migration flows, see Munshi (2014a) for an overview of previous evidence. However, identification of the network's role is difficult due to potential endogeneity, and there is scarce empirical evidence on the relative importance of networks compared to other factors, about the channels through which these networks help, and the role of different type of networks. In addition, little is known about the role social networks in the home location play in individual migration decisions. In this paper we take advantage of a large repeated individual-level crosssection dataset covering more than 150 countries to explore the importance of different types of social networks for the intentions to migrate internationally and domestically. We investigate the roles of both close social networks (composed of family and friends) and broad social networks (the share of people from/in the same country intending to migrate) not only at the destination but also at the origin, together with local and country-level amenities, labour market forces, wealth, and individual characteristics. Given the importance of social networks in influencing migration, gaining better understanding of these networks in driving migration is crucial.

The role of networks and the channels through which they influence migration decisions can be manifold (e.g. Munshi, 2014b). Networks abroad are expected to facilitate migration through several channels, ranging from simple information sharing to direct financial help or assistance in finding work (e.g. Boyd, 1989). The role of social networks at home can also be complex. Having closer ties with friends and family at home can facilitate migration through financial and other support, but can also reduce the intention to migrate due to financial or psychological reasons, for example Munshi and Rosenzweig (2016) examine disincentives due to financial motives.

In order to better understand the role and the different channels through which social networks matter, we explore the importance of close and broad social networks both abroad and in the origin location. In addition, we differentiate between close social networks abroad and at home based on whether the network provides financial support. Distinguishing social networks with and without financial aid allows us to better understand the channels through which social networks might influence migration intentions. In order to shed further light on how these different types of networks influence both domestic and international migration intentions we also run split-sample regressions based on individual's income and education.

This paper uses a new, detail-rich survey-based dataset, Gallup's World Poll. The survey contains numerous questions on how the respondents feel about the quality of local and countrylevel amenities, as well as a series of questions on the respondent's economic and demographic characteristics including information on remittances and social networks both abroad and in the current location. The survey also contains information on the intention to move away from the current location and allows us to distinguish between the intention to migrate domestically

\footnotetext{
${ }^{1}$ Intention is a stronger expression of the plan to migrate compared to aspiration or desire, which express interest in migrating under ideal circumstances. See Section 3 for further discussion.
} 
and abroad. This allows simultaneous analysis of international and domestic migration intentions using the same data source, something that was not explored in the previous literature. The actual internal migration is estimated to be about three times larger than actual international migration (Bell and Charles-Edwards, 2013; UNDP, 2009), thus better understanding the drivers of local migration and how those compare to international migration is also important.2

The data we use contain information on the intention to migrate and not on actual migration. While it is important to understand what drives the intention to migrate in itself, one might also ask how relevant the intention to migrate is for actual migration flows. The correlation between our data on international migration intentions and the actual migration flows for the OECD countries as destinations in 2010 is 0.46 . 3 Moreover, our data should also capture illegal migration, which leads to a downward bias of the official migration data. Several authors have shown that there is a high correlation between aspirations or intentions and the actual migration (Creighton, 2013; van Dalen and Henkens, 2008). In addition, we use a stricter definition of migration intention than most other studies, using a combination of questions which identify individuals who are more likely to act upon their intentions (if we were just to calculate migration intentions based on a simple question whether the individual would like to move, we would have about 11 times more individuals with migration intention/aspiration than what we have when using a combination of questions).

A considerable challenge when one empirically investigates the importance of peer effects is to identify what drives the correlation between individual migration intentions (or decisions) and peers' migration (social networks). In particular there could be prior similarities between individuals and individuals belonging to the same group resulting in similar behaviour as they face a common environment (re: "correlated effects" in Manski, 1993). This leads to endogeneity problems stemming from omitted variable bias. In order to test the robustness of our results without using instrumental variables and to establish causality, we undertake an instrumental variable regression approach. Both close and broad networks abroad could potentially be endogenous, hence we need instruments for both. As instruments for close networks abroad we use the region-level average perception of main factors influencing individual migration intentions. The members of the individual's close network abroad (close friends and relatives who have already emigrated abroad) were most likely based in the same region as the individual prior to moving abroad. Hence, average perception of the level of amenities, and average income at region level are external factors which are expected to influence the individual's close networks abroad. On the other hand, for the individual's migration intentions, what matters is its own perception of these factors, for which we control for in the regressions. Similarly, broad social networks abroad are likely to be highly correlated with country-level average perception of determinants of migration, such as perception of labour markets, economic and political conditions or amenities in the country of origin. Hence we use the country-average perception

\footnotetext{
${ }^{2}$ We use the terms 'local', 'internal' and 'domestic' interchangeably in the context of migration.

${ }^{3}$ To obtain this correlation we matched our data for the year 2010 to actual bilateral migration stock data with OECD countries as destination countries from Brücker et al. (2013). To be able to merge our data, we aggregated up individual responses using the survey weights to obtain bilateral international migration intentions.
} 
of these factors as instruments for broad networks.

Our results indicate that social networks are the most important factors influencing migration intention. Having close friends or family abroad increases significantly the probability of migration intention, explaining about 18 percent of the variation in the intention to migrate internationally. On the other hand, close networks at the current location reduce the likelihood of the intention to migrate both internationally and locally, albeit these networks are much less important for international migration intention than close networks abroad. Broad social networks also matter, increasing both local and international migration intentions. Broad social networks explain about 19 percent of the variation in the probability of international migration intention and more than 20 percent of local migration intention.

When splitting the sample by income and education level of individuals, we find that while close networks abroad with remittances are more important than those without remittances for all groups, they are relatively more important for highly educated individuals. Social networks with remittances increase the likelihood of international migration intention by about 2.75 times more than social networks without remittances for highly educated individuals, while only about 1.68 times more in case of individuals with low education and about 2.1 times more for medium-educated individuals. These results could indicate that close networks abroad which provide remittances play a role in reducing migration costs, and additionally, for highly educated individuals, also send a signal about potential assistance in finding better paying jobs.

We also find that close local social networks tend to matter more for domestic than international migration intentions. In addition, close local network from which the individual receive financial assistance is less of a restraining force for migration intentions. This could be because in networks from which they do not receive remittances they are more likely to have others relying on them, making migration more difficult. In addition, while all kinds of social networks matter for low- and medium-educated individuals (including broad and close social networks), for individuals with high education only close networks abroad have a significant impact on their migration intentions, and most importantly, close foreign networks with financial assistance.

We also find that satisfaction with local amenities is important for migration decisions, especially for local migration intention. Local amenities are more important than work-related factors, country-level amenities, or wealth, and explain about 8 percent in the variation of the probability of international migration intention and about 14 percent in the case of local migration intention. On the other hand, we find that wealth has only a marginal impact on the intention to migrate internationally, and it is insignificant in some of the sub-sample regressions.

\section{Related literature}

Research on network effects has emphasized the role of social networks or diasporas in lowering migration costs and thus increasing migration flows (McKenzie and Rapoport, 2007, 2010; Massey, 1993). 目 Beine et al. (2011) find that diaspora effects explain about $71 \%$ of

\footnotetext{
${ }^{4}$ We also explored other possible instruments, including questions related to perception of safety, infrastructure, corruption (business and government), healthcare, confidence in elections and country leadership.

${ }^{5}$ Migrant networks can also play a role not only in stimulating further migration flows, but also increasing
} 
the variation of the observed variability in migration flows. Social networks in the destination region can facilitate migration and can also increase the returns to migration through facilitating obtaining a job or higher wages (Boyd, 1989; Donato et al., 1992). Munshi (2003) also finds that origin community's networks in the destination can result in better labor market outcomes for migrants belonging to such networks. Several papers look at the differential impact social networks have on different skill-groups of the population. Beine and Salomone (2012) and Beine et al. (2011) both find that diaspora effects are significantly higher for low-skill migrants due to the large diaspora lowering the advantage higher levels of human capital generate in lowering migration costs.

The literature on network effects typically uses data on social networks at destination (most often proxied by the stock of migrants from a specific country or region), but excludes from the analysis the role of social networks at the origin. An exception to this is Munshi and Rosenzweig (2016), who find that low spatial mobility in India is consistent with the hypothesis that access to sub-caste networks at the origin provides mutual insurance to their members (risk-sharing network) and reduces the incentives to out-migrate. In particular, they find that among households with similar income, those who belong to higher-income caste networks are less likely to out-migrate and more likely to participate in caste-based insurance arrangements. Furthermore, most studies on international migration used aggregate level data on migrant networks without being able to distinguish close networks abroad.6 The data used in this paper allow us to analyse the role of social networks exploring the importance of both close networks (proxied by family and friends) together with broad networks (proxied by the share of population intending to migrate) both abroad and at the current location.

While the role of labour market characteristics and income for both international and domestic migration has been widely investigated in the literature, the role of amenities in comparison to these factors has been only limitedly explored, especially for international migration even though our findings indicate that amenities can be more important than work or income. Most studies examined the role of local amenities for within-country migration decisions with almost all studies considering amenities as pull factors, see Mulligan et al. (2004) and Knapp and Gravest (1989) for an overview of this literature. In addition, most of the papers on the relative role of amenities use data for a single country limiting the analysis only to the internal migrants, for example Niedomysl and Hansen (2010), Scott (2010), and Chen and Rosenthal (2008). In this paper we look at the effects of amenities on intentions to migrate both internationally and locally, measuring different types of amenities both at the local and country levels, capturing

trade and FDI flows between the origin and destination regions, see De Simone and Manchin (2012) and Javorcik et al. (2011) with high-skilled migrant networks, and stimulating technological transfer and innovation, see Kerr (2008). There are several strands of related literature with most focusing on actual migration rather than intention to migrate. The economic determinants of migration have been extensively explored in the literature both for domestic and international migration, mostly by considering employment, wages, social security, inequality, size of the labour market as potential push and pull factors, see Ortega and Peri (2009), Hatton and Williamson (2002), and Mayda (2010) for an overview of this literature, and considering factors influencing the cost of migrating, such as network effects, cultural links, distance, language, see Banerjee (1983), Mayda (2010), McKenzie and Rapoport (2007), Takenaka and Pren (2010), and Zavodny (1997).

${ }^{6}$ With the exception of country-specific studies, most importantly a series of studies relying on the Mexican Migration Project, for example Flores-Yeffal and Aysa-Lastra (2011). 
not just cultural/entertainment/recreation amenities (e.g. Niedomysl and Hansen, 2010), but also public goods (healthcare, education, safety, roads, physical setting and other local factors) and institutions (military, government, corruption, leadership).

The existing empirical research on migration is typically separated between international and domestic migration, mostly due to data limitations. A few studies are able to cover both international and local migration, but they are based on data for a single country or a specific region, e.g. Mendola (2008) and van Dalen and Henkens (2008).

The World Poll dataset has been so far used only by few papers. Concentrating on the importance of wealth constraints on migration using the World Poll, but without distinguishing local and international migration, Dustmann and Okatenko (2014) find that the level of migration costs relative to wealth determines the form of the relation between income and outmigration intentions. $\mathrm{G}$ In addition, they also find that contentment with local amenities plays an important role for migration decisions. Docquier et al. (2014) use the World Poll employing just a single question to identify migration aspiration (based on the question whether the person would like to move or not), and aggregate the individual-level survey to country-level to examine the main factors turning international migration intentions into actual migration. 8

In the next section we outline stylized model we use as a framework for setting up our empirical specification. Section 3 contains description of the dataset, including the principal component analysis, which we undertake to construct the indexes used in the paper. We then proceed by outlining a simple framework followed by a description of the empirical specification. In section 5 we present and discuss the results. The last section concludes the paper.

\section{Theoretical framework}

This section outlines a highly stylized model of how an individual's intention to migrate is affected by factors abroad and at the current location, such as contentment with amenities at the current location, with employment status, current and anticipated wealth and income, and the costs of migration. The objective of this model is to provide a motivation for the empirical analysis in Section 4, rather than to develop a comprehensive model. This framework is based on the framework used by Dustmann and Okatenko (2014) and Sjaastad (1962).

Given that the data used in this paper is based on a survey of individual preferences (and intentions), the model will be based on the individual's preference towards migration rather than on the actual fact of relocation. Specifically, the individual's preference towards migration (within a country or abroad) will depend on whether they anticipate that their expected utility at the intended destination will be higher compared with the expected utility at the current

\footnotetext{
7 In our paper we are able to distinguish between international and local migration intentions which is important since the majority of the out-migrants intends to migrate domestically. In our sample, for every person that expressed intention to migrate internationally, there are almost 9 people that intend to migrate domestically. See Table 38 .

${ }^{8}$ Also, see Esipova et al. (2011) for a descriptive analysis of migration trends using the World Poll dataset. In addition, Calvo et al. (2012) analyse global patterns of well-being; Olgiati et al. (2013) looks at the link between income and wellbeing; and Lovo (2013) examines the role of life satisfaction in the destination for explaining migration preferences.
} 
location. In line with Dustmann and Okatenko (2014), the utilities depend on the individual's wealth and contentment with amenities, while costs can vary with individual- and countryspecific characteristics. In addition to this, the expected costs of migration can be influenced by migration networks at the destination (e.g. McKenzie and Rapoport, 2007) and social networks at the origin (e.g. Munshi and Rosenzweig, 2016; Sjaastad, 1962).

In our framework, if an individual perceives their expected utility to be higher at another location (net of the expected costs of relocation), then they will develop an aspiration (or desire) to migrate. This is a relatively weak indication of a preference towards migration, because it does not indicate a firm intention to out-migrate. Assuming that the individual faces credit constraints, if expected costs of migration are too high, then the individual's aspiration to migrate will remain only a 'dream'. Those individuals that have an aspiration to out-migrate and can afford the move, will develop an intention to migrate. Intention to migrate is a stronger expression of the plan to migrate.

Let the individual expected utility from staying at the origin be given by $u_{o}$, while the expected utility at another location is given by $u_{d}$. If the expected costs of migration are given by $c$, then the individual will develop an aspiration to migrate if the following condition is satisfied (individual subscripts are dropped for convenience):

$$
u_{o}-\left(u_{d}-c\right) \leq 0
$$

In order for an individual to develop an intention to migrate, the individual's current wealth, 9 $\omega_{o}$, must be sufficient to finance the expected costs of migration (budget constraint):

$$
\omega_{o} \geq c
$$

In line with Sjaastad (1962) the migration costs will be influenced by country-specific characteristics, $\tau$, individual-specific characteristics, $i$, and, importantly, the individual's social networks at the origin $\delta_{o}$ and destination $\delta_{d}$ :

$$
c=c\left(\tau, i, \delta_{o}, \delta_{d}\right)
$$

Social networks at the destination are expected to lower the costs of migrating through providing information, financial or other type of direct help for migrants. Social networks at the origin on the other hand can both increase or decrease migration costs. For example, it can be that these networks provide financial support to people who want to migrate, but it could also be that emigrating would imply losing the benefits offered by the social networks at home, either emotional (re: "psychic costs" in Sjaastad, 1962) or financial (Munshi and Rosenzweig, 2016), thus increasing the costs of migrating.

Allowing for unobservable factors that can affect the utility of the individual at the desti-

\footnotetext{
${ }^{9}$ It is important to distinguish wealth, a stock concept, from income, a flow concept. However, in the context of the empirical approach used in this paper both are relevant for the development of an intention to out-migrate, and the discussion will refer to wealth only.
} 
nation and origin and the cost of migration, Equation 11 can be written as:

$$
u_{o}-\left(u_{d}-c\right)+\sigma \leq 0
$$

where $\sigma$ captures the net value of the random variables affecting utilities at destination/origin and the cost of migration. This means that the probability of an individual developing an aspiration to migrate will be given by:

$$
\operatorname{Pr}(\text { aspiration })=\operatorname{Pr}\left(\sigma \leq u_{d}-c-u_{o}\right)
$$

The probability of developing an intention to migrate will also depend on the budget constraint:

$$
\operatorname{Pr}(\text { intention })=\operatorname{Pr}\left(\sigma \leq u_{d}-c-u_{o} ; \omega_{o} \geq c\right) .
$$

This model allows distinguishing aspiration from intention and predicts that individuals will be more likely to develop an intention to out-migrate away from the current location if, other factors constant, they have stronger social networks at the destination.

\section{Data}

The key source of data used in this paper is a large annual survey, Gallup's World Poll. The survey covers residents of more than 150 countries, representing about $98 \%$ of the world's adult population. The information is collected from randomly selected, nationally-representative samples of about one thousand individuals per country.10 The survey covers each country comprehensively, including rural areas.11 Although the World Poll contains data from 2005 onwards, we limit our sample to waves 5 to 7 , which cover 2010 to 2013 calendar years (see the list of countries included in the sample in Appendix G). The reason for using this shorter sample is that we can distinguish between local and international migration intentions only in these waves of the survey.

\subsection{Identifying aspirations and intentions}

Several questions in the survey ask about the individual's preferences for moving abroad. In particular, a questionasks if the individual would like to move to another country under ideal circumstances. This question is used to identify individuals with aspiration for international migration.12 Another relevant question, asks whether the individual is planning to move permanently to another country within the next 12 months. This question is used to identify individuals with intention to migrate internationally. The last question used in constructing

\footnotetext{
${ }^{10}$ In some countries, larger samples are collected in major cities or areas of special interest. Additionally, in some large countries, such as China and Russia, sample sizes increase to at least two thousand respondents. ${ }^{11}$ See further details on the dataset and a full list of available variables in Esipova et al. (2011) and Gallup (2012).

${ }^{12}$ We are unable to identify individuals that only aspire to migrate within a country.
} 
the dependent variableasks if the individual is likely to out-migrate away from their current location within the next 12 months. This question is used in combination with the previous questionto identify individuals with intention to migrate locally. The number of observations in each category is given in Table 38. Further details on the procedure used in construction of these variables, related questions and limitations of the procedure can be found in Appendix E.

\begin{tabular}{rcc}
\hline Label & Total & $\begin{array}{c}\text { As \% of valid } \\
\text { observations }\end{array}$ \\
\hline Intention to stay at the current location & $367^{\prime} 957$ & 85.2 \\
Intention to migrate locally & $57^{\prime} 407$ & 13.3 \\
Intention to migrate internationally & $6^{\prime} 472$ & 1.5 \\
\hline Valid observations & $431^{\prime} 836$ & 100 \\
\hline
\end{tabular}

Table 1: Intention to stay or to migrate locally or internationally - summary numbers.

Note: valid observations are observations with consistent, non-missing responses, see Appendix $\mathrm{E}$ for further details. Source: own calculations based on World Poll data.

The data we use contain information on the intentions to migrate and not on actual migration. We believe that it is important to understand what drives the intention to migrate in itself. Nevertheless, one might also ask how relevant is the intention to migrate for actual migration flows. An advantage of using intentions to migrate instead of actual migration is that it provides a measure of migration propensities that includes potential illegal migrants, which are omitted from most migration statistics. On the other hand, a possible concern with using the intentions to migrate is whether intentions are "mere words or true plans" (van Dalen and Henkens, 2008). Using data for the Netherlands, van Dalen and Henkens (2008) find that intentions are a good predictor of future migration. In addition, within people who expressed intention to migrate those who stayed do not differ from those who migrated (with the exception of weaker health for those that stay). Furthermore, the same forces drive actual migration and the intention to migrate. Creighton (2013) uses two waves of the Mexican Family Life Survey and shows that aspirations predict migration, both interstate and to the US from Mexico. These results point out that intentions are good predictors of actual future migration. The intentions are defined in our data more strictly than aspirations defined in Creighton (2013), thus we are likely to get an even better prediction for actual migration. With a less strict definition for migration intentions than what we use in our empirical specifications, using just a single question whether the individual would like to migrate or not, we would identify up to eleven times more individuals with international migration intention.13

\footnotetext{
${ }^{13}$ Aspiration is a statement of consideration to migrate (perhaps under ideal circumstances), for example Creighton (2013) uses: "Have you thought about moving in the future outside the locality/community where you currently live?" On the other hand, intention is a stronger statement of preferences. The corresponding question in World Poll is: "Ideally, if you had the opportunity, would you like to move permanently to another country, or would you prefer to continue living in this country?" World Poll's formulation is stronger since it is asking directly for the likely response under ideal conditions (as opposed to mere consideration used by Creighton, 2013). Furthermore, while Gallup's data allows for analysis of aspirations to migrate (using the previously cited question), we employ an even stronger definition of intention by combining the previous question with information from the following questions: "In the next 12 months, are you likely or unlikely to move away from the city or area where you live?" and "Are you planning to move permanently to another country in the next 12 months, or not?"
} 
In order to check to what extent our constructed variable on international migration intention can be a proxy for actual migration, we merged our data with actual bilateral migration stock from Brücker et al. (2013). This dataset provides the number of migrants in the destination country originating from a given country based on census data for the years 1980-2010 for every five years. From this we are able to calculate the yearly average net bilateral flows (just taking the difference between the stocks) and match this to our data. In order to compare the actual flows with the intentions from our data, we aggregate the responses from our data to country level using information on the desired destination country. The correlation between our data on international migration intentions and the actual migration flows for 2010 is 0.46 . Unlike the official data, our data should also capture illegal migration, which can explain some of the discrepancy between intention and actual (official) flows. Overall, we believe that using intentions can be a good proxy for actual migration, nevertheless, throughout this paper we discuss intentions without drawing conclusions for actual migration.

\subsection{Descriptive statistics}

Table 2 provides descriptive statistics on the sample's demographic characteristics, distinguishing between respondents who intend to stay in their current location, those who intend to migrate to another location within the same country, and those who intend to migrate internationally (see Appendix $\mathrm{E}$ on how each category was defined).

The basic descriptive statistics for demographics are in line with the previous findings in the literature. Those who intend to migrate are more likely to be young, single, male, and with better education. This pattern is stronger for international migration intentions than for local migration intentions. In addition, those who intend to migrate internationally tend to come from households with larger number of adults and children.

Those who intend to migrate are also different from stayers in other respects. Those who intend to migrate internationally have more relatives abroad than those who intend to migrate locally. In addition, those who intend to migrate are also more likely to come from major cities. Those who intend to migrate internationally report that they tend to spend more time socializing with friends, relatives and family, on the other hand, those who stay report that they can count on family and friends more. In addition, a greater share of those who intend to migrate internationally perceive themselves to be healthy. 14

Stayers tend to be much more satisfied with the area where they live than those who intend to move (see Table 3). Satisfaction with country-level factors is similar between those who intend to migrate locally (even a bit higher) and stayers, while much lower for those who intend to migration internationally. While poorer (in absolute terms) people intend to migrate more, when using income quintiles within country, those who are relatively richer compared to the population in the country are more likely to intend to migrate. People who are unemployed are also more likely to intend to migrate locally, and even more so internationally.

\footnotetext{
${ }^{14}$ Regression results show that better self-reported health status of out-migrants is mostly explained by their (younger) age.
} 


\begin{tabular}{lccc}
\hline & $\begin{array}{c}\text { Intention to } \\
\text { stay }\end{array}$ & \multicolumn{2}{c}{ Intention to migrate } \\
locally & internationally \\
\hline Respondent's age & 40.7 & 33.2 & 29.9 \\
Female & $(17.82)$ & $(14.74)$ & $(12.21)$ \\
Education & 0.52 & 0.50 & 0.42 \\
& $(0.50)$ & $(0.50)$ & $(0.49)$ \\
Married & 1.67 & 1.71 & 1.75 \\
& $(0.65)$ & $(0.65)$ & $(0.66)$ \\
\# of adults & 0.61 & 0.50 & 0.39 \\
& $(0.49)$ & $(0.50)$ & $(0.49)$ \\
\# of children & 3.64 & 3.87 & 4.34 \\
& $(1.79)$ & $(1.90)$ & $(2.13)$ \\
Relatives live(+lived) abroad & 1.34 & 1.58 & 1.87 \\
Time spent with family/friends & $(1.67)$ & $(1.78)$ & $(2.04)$ \\
& 0.14 & 0.18 & 0.54 \\
Healthy & $(0.35)$ & $(0.38)$ & $(0.50)$ \\
& 5.78 & 5.68 & 6.53 \\
Large city & $(5.11)$ & $(5.01)$ & $(5.57)$ \\
Friends/family can help & 0.75 & 0.76 & 0.78 \\
Close networks abroad & $(0.43)$ & $(0.43)$ & $(0.41)$ \\
& 0.41 & 0.45 & 0.48 \\
& $(0.49)$ & $(0.50)$ & $(0.50)$ \\
& 0.81 & 0.79 & 0.79 \\
& $(0.39)$ & $(0.40)$ & $(0.41)$ \\
& 0.27 & 0.34 & 0.67 \\
& $(0.45)$ & $(0.47)$ & $(0.47)$ \\
\hline
\end{tabular}

Table 2: Descriptive statistics - demographic characteristics.

Note: weighted sample. Figures in the brackets show standard deviation. Source: own calculations based on World Poll data.

\begin{tabular}{|c|c|c|c|}
\hline & $\begin{array}{l}\text { Intention to } \\
\text { stay }\end{array}$ & $\begin{array}{l}\text { Intent } \\
\text { locally }\end{array}$ & $\begin{array}{l}\text { on to migrate } \\
\text { internationally }\end{array}$ \\
\hline Satisfaction with the city/area & $\begin{array}{c}0.84 \\
(0.37)\end{array}$ & $\begin{array}{c}0.64 \\
(0.48)\end{array}$ & $\begin{array}{c}0.51 \\
(0.50)\end{array}$ \\
\hline Economic conditions in the city & $\begin{array}{c}0.53 \\
(0.50)\end{array}$ & $\begin{array}{c}0.46 \\
(0.50)\end{array}$ & $\begin{array}{c}0.31 \\
(0.46)\end{array}$ \\
\hline Change in the city's economic condition & $\begin{array}{c}1.13 \\
(0.83)\end{array}$ & $\begin{array}{l}1.09 \\
(0.86)\end{array}$ & $\begin{array}{c}0.82 \\
(0.87)\end{array}$ \\
\hline Economic conditions in the country & $\begin{array}{l}1.05 \\
(0.85)\end{array}$ & $\begin{array}{c}1.11 \\
(0.89)\end{array}$ & $\begin{array}{c}0.82 \\
(0.87)\end{array}$ \\
\hline Change in the country's economic conditions & $\begin{array}{l}1.02 \\
(0.87)\end{array}$ & $\begin{array}{l}1.07 \\
(0.88)\end{array}$ & $\begin{array}{c}0.83 \\
(0.88)\end{array}$ \\
\hline Household Income (International Dollars) & $\begin{array}{c}14,048 \\
(18,789)\end{array}$ & $\begin{array}{c}12,786 \\
(17,870)\end{array}$ & $\begin{array}{c}10,398 \\
(15,219)\end{array}$ \\
\hline Household Income Within Country Quintiles & $\begin{array}{c}2.92 \\
(1.40)\end{array}$ & $\begin{array}{c}3.00 \\
(1.41)\end{array}$ & $\begin{array}{c}3.14 \\
(1.45)\end{array}$ \\
\hline Employment & $\begin{array}{c}1.40 \\
(0.59)\end{array}$ & $\begin{array}{l}1.34 \\
(0.65)\end{array}$ & $\begin{array}{l}1.25 \\
(0.71)\end{array}$ \\
\hline
\end{tabular}

Table 3: Descriptive statistics - economic characteristics and contentment with amenities. Note: weighted sample. Figures in the brackets show standard deviation. Source: own calculations based on World Poll data. 


\subsection{Variable construction with principal component analysis}

In the survey there are many questions which are relevant for our analysis and are related to similar issues, however the resulting variables are highly correlated. To include just one variable for a given topic would lead to omitting some important information about the factors which might alter the respondent's intention to migrate. To address this, instead of just limiting the analysis to one of these questions, we retain as much information as possible in the underlying data and use principal component analysis to produce a set of indexes in our main specifications.

Principal component analysis is a useful statistical technique that has been widely applied in fields such as face recognition and image compression, and is a common technique for finding patterns in data of high dimensionality. Ideally, principal component analysis identifies patterns in the data and based on these patterns it reduces the number of dimensions of the data without a large loss of information. It reduces the data to a few principal components by using the variance structure of the matrix of data through linear combination of the variables. Given that most of the variables used for constructing the indexes are not continuous, we use polychoric principal component analysis developed by Kolenikov and Angeles (2004). 15

The summary of the results of the principal component analysis is shown in Table 4 (further details, including the list of underlying questions and scoring coefficients, can be found in Appendix B). Our main objective in using principal component analysis is to reduce the dimensionality of the data. The original survey questions were grouped in categories by Gallup. Following these categories, and limiting the data to questions which were available for most years and countries, we group questions into the following categories to undertake the principal component analysis: 'local amenities and local security', 'country contentment and corruption', 'work', 'wealth and standard of living', 'close local networks'. For some of these categories only two or three questions were available for sufficient coverage. In these cases we only retain the first component. When more than three underlying variables were used, we retain the first two components of the principal component analysis. This is also supported by the eigenvalues being greater or close to 1 , which is a widely used cut-off rule (see Hatcher and O'Rourke, 2014). 16 Thus we retain the first component for the 'work' and 'close local networks', and the first two components for 'wealth and standard of living', 'local amenities and secuirty', and 'country contentment and corruption'. For each category the resulting components together reflect between roughly 60 and $67 \%$ of variation of the underlying sample (indicated in the table by the cumulative proportion explained). All indexes were scaled to range from 0 to 1.

The first category measures contentment with local/city-level amenities and security, for which, we retain the first two components (see Appendix B.1). The construction of these components includes questions on individual satisfaction with various factors related to infrastructure in the city, safety, housing, and other characteristics of the city or area where the individual is located. The proportion explained by the first component, which we call 'local amenities', is $47 \%$ (see Table 4 ) and the cumulative proportion with the second component,

\footnotetext{
${ }^{15}$ As a robustness check we also run standard principal component analysis and the results are very similar.

${ }^{16}$ Every variable contributes one unit of variance to the total variance in the dataset, so the component with eigenvalue greater than 1 represents greater variance than was contributed by a single variable.
} 


\begin{tabular}{|c|c|c|c|c|}
\hline \multirow[b]{2}{*}{ Category } & \multirow[b]{2}{*}{ Component } & \multicolumn{3}{|c|}{ Proportion Cumulative } \\
\hline & & Eigenvalue & explained & proportion \\
\hline Local amenities and security & Local amenities & 3.76 & 0.47 & 0.47 \\
\hline Local amenities and security & Local security & 0.99 & 0.12 & 0.59 \\
\hline Country contentment and corruption & Contentment with the country & 4.11 & 0.51 & 0.51 \\
\hline Country contentment and corruption & Corruption & 1.31 & 0.16 & 0.67 \\
\hline Work & Work & 1.90 & 0.63 & 0.63 \\
\hline Wealth and standard of living & Wealth & 3.96 & 0.44 & 0.44 \\
\hline Wealth and standard of living & Standard of living & 1.39 & 0.15 & 0.59 \\
\hline Close local networks & Close local networks & 1.21 & 0.60 & 0.60 \\
\hline
\end{tabular}

Table 4: Overview of the constructed indexes.

Note: for further details on the indexes, including the list of underlying questions and scoring coefficients, see Appendix B.

which we call 'local security', is $59 \%$ with an eigenvalue close to 1 . While the first component mainly captures satisfaction with local healthcare, education, and roads, the second component is mostly reflecting perception of personal safety in the location.

The second category, 'country contentment and corruption', for which two components were retained, measures satisfaction with amenities at the respondent's country of residence (Appendix B.2). This is constructed from questions related to satisfaction with economic situation, governance, military, and corruption in the country. The first component, which we call 'contentment with country', explains $51 \%$ variation in the sample, with confidence in the national government, and the economic conditions being the most important underlying factors while corruption is the least important. On the other hand, the second component, 'corruption', explaining jointly with the first component $67 \%$ of the variance, is mainly capturing business and government corruption in the country. Larger values of this index correspond to lower perception of corruption in government and business.

The next category for which we retain two components is 'wealth'. The resulting indexes capture the level of wealth of the respondent through taking into account not only the actual income, but also other factors related to wealth and the standard of living (Appendix B.4). The index is constructed using 10 questions from the survey, including household income by quintiles, individual perception and satisfaction with income and the standard of living, expectations about future standard of living, and possession of various assets. The first two components jointly explain $59 \%$ of the underlying variation. While the first component, which we call 'wealth', is mostly capturing actual income, the perception of income, and wealth, the second component, which we refer to as 'standard of living', is about the current and, more importantly, expected standard of living.

For the two remaining categories, only the first components were retained. The first, 'close local networks', measures the importance of social ties/networks of the respondent in her current location and is composed of two questions related to the individual's connections to friends and relatives, both used with about the same weights for the construction of the index (Appendix B.5). The proportion explained by the component is $60 \%$ with an eigenvalue of 1.2 . The final category for which principal components were calculated proxies for the respondent's satisfaction with her work situation and employment status (Appendix B.3). It includes the 
individual's satisfaction with her/his job, in addition to including perception of job opportunities and actual employment status (unemployed, out of workforce, looking for job, working). We retain the first component, which has an eigenvalue of 1.9, and the proportion explained by it is $63 \%$ and we call it 'work'.

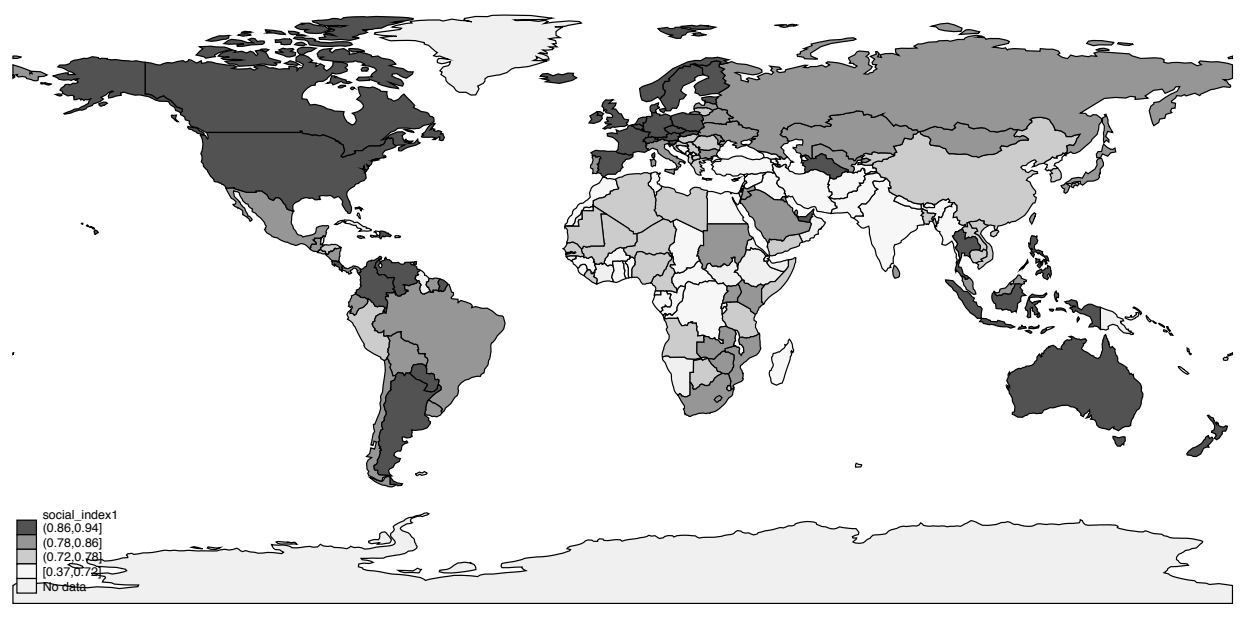

Figure 1: Close local networks across countries.

Source: own calculations based on World Poll data.

The mean value of the close local network variable by countries is depicted in Figure 1. Countries with strong close networks abroad also tend to be ones where close local networks are strong (not shown).

\section{The empirical specification}

Given our data, we concentrate the empirical analysis on origin-specific factors and factors influencing the cost of migration while disregarding the choice of destination. Following the framework outlined earlier, our main empirical specification is:

$$
M_{i t}=\alpha+\beta_{1} Y_{i t}+\beta_{2} Y_{i t}^{2}+\beta_{3} A_{i t}+\beta_{4} W_{i t}+\beta_{5} S_{i t}+\beta_{6} I_{i t}+\beta_{7} C_{t}+\gamma+\mu+\epsilon_{i t},
$$

where $M_{i t}$ is a variable equal to 1 if the individual $i$ surveyed in year $t$ intends to out-migrate over the next 12 months.17 We distinguish between local (within country) and international migration intentions. Equation 8 will be estimated separately for individuals that intend to move locally and internationally using sample-weighted probit regressions. 18

$Y_{i t}$ is a variable measuring individual $i$ 's level of wealth in year $t$. For this, in our main specification we will use the first two components obtained with the principal component analysis,

\footnotetext{
${ }^{17}$ Our data does not have a panel structure as we do not observe the same individuals asked in subsequent years.

${ }^{18}$ For respondents that intend to move locally $M_{i t}$ will be equal to one if the individual plans to migrate within the country and zero if she does not have plans to migrate. Similarly, in regressions for international migration intention $M_{i t}$ is equal to one if the individual intends to move to another country and zero if she plans to stay in the same location.
} 
'wealth' and 'standard of living', described in Appendix B. As a robustness check we also run the regressions using a single question instead of the variables obtained with principal component analysis. For wealth we use the individual's income (measured in international dollars). 19

$A_{i t}$ is satisfaction with amenities at city/local and national level. To measure contentment with local or city-level amenities, in our main specification we use 'local amenities' and 'local security', which measures contentment with amenities including contentment with local infrastructure, safety, and economy (see Appendix B.1). As a robustness check we also use a single variable instead of the constructed indexes, for which we use the question "How satisfied are you with your city?". In order to measure contentment with amenities at national level, we use 'contentment with country' and 'corruption' measuring the individual's satisfaction with politics, infrastructure and economy in the country of residence (see Appendix B.2). As a single variable, we use the question "How would you rate economic conditions in this country today: as excellent, good, only fair, or poor?".

$W_{i t}$ proxies the individual's satisfaction with her job. In the main specification we use our constructed index 'work', capturing job satisfaction, job availability, and employment status (see Appendix B.3). As a robustness check, instead of the constructed index, we use the current reported employment status of the individual which takes the value 0 if unemployed, 1 if looking for a full-time job (while being employed) or out of the workforce, and 2 if employed.

$S_{i t}$ proxies for social networks. There are four types of social networks which we proxy for in the empirical analysis. We control for close networks and broad networks both at the current location and abroad. We measure close social networks abroad by using the question "Do you have relatives or friends who are living in another country whom you can count on to help you when you need them?". In order to control for close local social networks we use the constructed 'close local network' variable (see Appendix B.5) and in the alternative specification we use the question "In the city or area where you live, are you satisfied or dissatisfied with the opportunities to meet people and make friends?". We also measure the impact of broad social networks. When looking at the determinants of international migration intention, broad social network abroad is defined as log of the share of individuals intending to move abroad from the same country. When we look at domestic migration intention, broad social networks are measured by log of the share of individuals intending to move within the same country.

$I_{i t}$ are individual observable characteristics including the level of education, marital status, age, gender, health, number of children, and a dummy for residing in a large city which could all influence migration costs.

\section{Results}

\subsection{Main results}

In the text throughout, we discuss the results using marginal effects, which are evaluated at the means, thus reflecting the probability of intention to migrate for someone with 'typical' values

\footnotetext{
${ }^{19}$ For further details on methodology behind the income variable see Gallup (2012, page 9).
} 
of the explanatory variables. Results with our principal component-based indexes (Equation 7) are presented in Table 5. The table shows marginal effects and all specifications include country and year fixed effects.20 Both linear and non-linear (with quadratic terms for the 'wealth' and 'standard of living' variables) specifications are presented for international and local migration intention regressions.

The results indicate a significant correlation between social networks and intention to migrate. Having close social networks abroad is associated with higher probability of migration intention, with those individuals who have social networks abroad (with otherwise average characteristics) being $3.4 \%$ more likely to intend to migrate internationally. On the other hand, having stronger close local networks at the current location is negatively correlated with the likelihood of the intention to migrate both internationally and locally. In addition, broad social networks also have a positive correlation, and this is true both for local and international migration intentions indicating potential domestic and international network effects.

For both internal and international migration intentions, satisfaction with local circumstances, measured by the local amenities and local security, decreases the probability of moving away from the current location. Both variables are significant, with higher coefficients for those who intend to migrate locally. Contentment with the country only influences international migration intentions, not domestic migration intentions, and is less important than contentment with local amenities. Furthermore, lower corruption in the country also decreases international migration intention, although the variable is only significant at $10 \%$.

The marginal effect of wealth on the probability of the intention to migrate internationally is positive and significant at $10 \%$. The quadratic term of the 'standard of living' variable is found to be insignificant, while the quadratic term of wealth is only significant for the local migration intentions. The marginal effect of the 'standard of living' is negative and significant, indicating that as the perception of the current and future expected standard of living improves, the probability that an individual intends to migrate decreases. A closely related result is obtained by Dustmann and Okatenko (2014), who use the same dataset, although over earlier time period, to investigate the effects of wealth constraints in different regions. Dustmann and Okatenko (2014) find that higher wealth leads to higher out-migration intention, without distinguishing local and international migration, in sub-Saharan Africa and Asia, while wealth is an insignificant determinant in the richest region in their sample - Latin America.

While current wealth of the individual is only marginally important, if her current work conditions are better, she is less likely to intend to migrate locally or internationally, with the effect being more important for local migration intention. Being younger and perceiving ones own health worse leads to higher probability of international and internal migration plans.21

\footnotetext{
${ }^{20}$ As a robustness, we dropped the country-year varying explanatory variables and run the regressions with country-year fixed effects. In addition, we also run random effects probit regressions to see the robustness of our results to the estimator used. The results are very similar, and all results hold. The results are available upon request from the authors.

${ }^{21}$ This latter result is surprising, because the literature generally argues for positive selection for health. In the specifications that do not contain age, the health coefficient is positive, however as soon as age is controlled for, health coefficient becomes negative or insignificant. The result persists with age-health interaction. Partly this result could be explained by the different data used. The literature typically uses data on actual migrants
} 
In addition, better-educated individuals are more likely to intend to migrate both locally and internationally in line with previous research (e.g. Docquier et al., 2012; Docquier and Rapoport, 2012). The results also indicate that people living in larger cities are more likely to be mobile. This finding could be capturing individuals that have migrated from rural areas or small towns to large cities as an intermediate step in their international migration path (see King and Skeldon, 2010, page 1623 for further references) or it could be that the costs of migrating from a large city are lower.

So what do these results mean in terms of economic significance? While principal components provide a way to capture all information from the underlying data without multicollinearity problems arising, it has the drawback that the coefficients are more difficult to interpret compared to using single questions from the survey. In order to better understand the importance of the explanatory variables in explaining the migration intentions, we use the Shorrocks-Shapley decomposition. The Shorrocks-Shapley decomposition provides the relative contribution of variables of interest to a measure of fit (such as $R^{2}$ for OLS, or pseudo- $R^{2}$ for probit). This is done by considering all possible combinations of elimination of variables of interest and calculating marginal effects from each exclusion on the chosen measure of fit.22

The Shapley decomposition for our non-linear specification is presented in Figure 2. It shows the relative importance of each explanatory variable in explaining overall variation for the regressions of intention to migrate both internationally and locally.

Clearly, network effects explain most of the variation. Having close networks abroad accounts for about $18 \%$ of the variation in the intention to migrate internationally. Broad networks abroad (the share of people intending to migrate from the same country) explain about $19 \%$ for international migration intention, while local broad networks (share of individuals planning to migrate in the same country) explain a bit more than $20 \%$ for local migration intention. Thus, altogether, about $37 \%$ of variation in international migration intention is explained by different social networks abroad (close and broad networks). This finding is in line with the research linking social networks and cost of migration (e.g. McKenzie and Rapoport, 2007 use Mexican data to show that increase in the share of individuals with migration experience raises propensity to migrate internationally). On the other hand, close social networks at home are relatively less important, especially for those who intend to move internationally.

Satisfaction with local amenities is also important for migration decisions, with the two indexes, 'local amenities' and 'local security', explaining more of the variation in international and local migration intentions than the 'work index'. These are much more important than satisfaction with country-level amenities, which explains less than 2 percent in the case of domestic migration intention and about 5 percent in the case of international migration intention. Furthermore, we find that the importance of the individual's wealth and perceptions of standard

and compares them to the host population, while we compare those that intend to migrate (potential migrants) with those that intend to stay. Recent studies that compare migrants to non-migrants in the origin find that there is negative health selection (or, in some cases, health is not significant). For example, see Rubalcava et al. (2008) who find that for Mexico-US migration there is either very weak positive selection or a negative one, depending on the health measures used.

${ }^{22}$ See more details in Shorrocks (1982) and Dustmann and Okatenko (2014). 


\begin{tabular}{|c|c|c|c|c|}
\hline & \multicolumn{2}{|c|}{ Linear specification } & \multicolumn{2}{|c|}{ Non-linear specification } \\
\hline & & Intention & o migrate & \\
\hline & internationally & locally & internationally & locally \\
\hline Close local networks & $\begin{array}{c}-0.008 \\
(0.004)^{* *}\end{array}$ & $\begin{array}{c}-0.025 \\
(0.007)^{* * *}\end{array}$ & $\begin{array}{c}-0.008 \\
(0.004)^{* *}\end{array}$ & $\begin{array}{c}-0.026 \\
(0.007)^{* * *}\end{array}$ \\
\hline Close networks abroad & $\begin{array}{c}0.034 \\
(0.002)^{* * *}\end{array}$ & $\begin{array}{c}0.033 \\
(0.005)^{* * *}\end{array}$ & $\begin{array}{c}0.034 \\
(0.002)^{* * *}\end{array}$ & $\begin{array}{c}0.033 \\
(0.005)^{* * *}\end{array}$ \\
\hline Broad networks abroad & $\begin{array}{c}0.024 \\
(0.003)^{* * *}\end{array}$ & & $\begin{array}{c}0.024 \\
(0.003)^{* * *}\end{array}$ & \\
\hline Broad local networks & & $\begin{array}{c}0.103 \\
(0.018)^{* * *}\end{array}$ & & $\begin{array}{c}0.102 \\
(0.019)^{* * *}\end{array}$ \\
\hline Local amenities & $\begin{array}{c}-0.030 \\
(0.004)^{* * *}\end{array}$ & $\begin{array}{c}-0.104 \\
(0.009)^{* * *}\end{array}$ & $\begin{array}{c}-0.030 \\
(0.004)^{* * *}\end{array}$ & $\begin{array}{c}-0.105 \\
(0.009)^{* * *}\end{array}$ \\
\hline Local security & $\begin{array}{c}-0.020 \\
(0.005)^{* * *}\end{array}$ & $\begin{array}{c}-0.091 \\
(0.011)^{* * *}\end{array}$ & $\begin{array}{c}-0.020 \\
(0.005)^{* * *}\end{array}$ & $\begin{array}{c}-0.090 \\
(0.011)^{* * *}\end{array}$ \\
\hline Contentment with the country & $\begin{array}{c}-0.020 \\
(0.005)^{* * *}\end{array}$ & $\begin{array}{l}-0.013 \\
(0.012)\end{array}$ & $\begin{array}{c}-0.020 \\
(0.005)^{* * *}\end{array}$ & $\begin{array}{c}-0.012 \\
(0.012)\end{array}$ \\
\hline Corruption & $\begin{array}{c}-0.011 \\
(0.006)^{*}\end{array}$ & $\begin{array}{l}-0.010 \\
(0.017)\end{array}$ & $\begin{array}{c}-0.011 \\
(0.006)^{*}\end{array}$ & $\begin{array}{l}-0.010 \\
(0.017)\end{array}$ \\
\hline Work & $\begin{array}{c}-0.018 \\
(0.003)^{* * *}\end{array}$ & $\begin{array}{c}-0.059 \\
(0.009)^{* * *}\end{array}$ & $\begin{array}{c}-0.018 \\
(0.003)^{* * *}\end{array}$ & $\begin{array}{c}-0.058 \\
(0.008)^{* * *}\end{array}$ \\
\hline Wealth & $\begin{array}{c}0.011 \\
(0.006)^{*}\end{array}$ & $\begin{array}{c}0.016 \\
(0.020)\end{array}$ & $\begin{array}{c}0.010 \\
(0.006)^{*}\end{array}$ & $\begin{array}{c}0.008 \\
(0.019)\end{array}$ \\
\hline Standard of living & $\begin{array}{c}-0.025 \\
(0.008)^{* * *}\end{array}$ & $\begin{array}{c}-0.048 \\
(0.016)^{* * *}\end{array}$ & $\begin{array}{c}-0.024 \\
(0.008)^{* * *}\end{array}$ & $\begin{array}{c}-0.046 \\
(0.016)^{* * *}\end{array}$ \\
\hline Married & $\begin{array}{c}-0.011 \\
(0.002)^{* * *}\end{array}$ & $\begin{array}{c}-0.029 \\
(0.005)^{* * *}\end{array}$ & $\begin{array}{c}-0.011 \\
(0.002)^{* * *}\end{array}$ & $\begin{array}{c}-0.029 \\
(0.005)^{* * *}\end{array}$ \\
\hline Age & $\begin{array}{c}-0.001 \\
(0.000)^{* * *}\end{array}$ & $\begin{array}{c}-0.003 \\
(0.000)^{* * *}\end{array}$ & $\begin{array}{c}-0.001 \\
(0.000)^{* * *}\end{array}$ & $\begin{array}{c}-0.003 \\
(0.000)^{* * *}\end{array}$ \\
\hline Education (medium) & $\begin{array}{c}0.005 \\
(0.003)^{*}\end{array}$ & $\begin{array}{c}0.021 \\
(0.005)^{* * *}\end{array}$ & $\begin{array}{c}0.005 \\
(0.003)^{*}\end{array}$ & $\begin{array}{c}0.020 \\
(0.005)^{* * *}\end{array}$ \\
\hline Education (high) & $\begin{array}{c}0.011 \\
(0.004)^{* * *}\end{array}$ & $\begin{array}{c}0.041 \\
(0.007)^{* * *}\end{array}$ & $\begin{array}{c}0.011 \\
(0.004)^{* * *}\end{array}$ & $\begin{array}{c}0.044 \\
(0.007)^{* * *}\end{array}$ \\
\hline Female & $\begin{array}{c}-0.010 \\
(0.002)^{* * *}\end{array}$ & $\begin{array}{c}-0.017 \\
(0.006)^{* * *}\end{array}$ & $\begin{array}{c}-0.010 \\
(0.002)^{* * *}\end{array}$ & $\begin{array}{c}-0.017 \\
(0.006)^{* * *}\end{array}$ \\
\hline Large city & $\begin{array}{c}0.007 \\
(0.003)^{* *}\end{array}$ & $\begin{array}{l}0.008 \\
(0.006)\end{array}$ & $\begin{array}{c}0.007 \\
(0.003)^{* *}\end{array}$ & $\begin{array}{c}0.008 \\
(0.006)\end{array}$ \\
\hline Healthy & $\begin{array}{c}-0.009 \\
(0.003)^{* * *}\end{array}$ & $\begin{array}{c}-0.041 \\
(0.010)^{* * *}\end{array}$ & $\begin{array}{c}-0.009 \\
(0.003)^{* * *}\end{array}$ & $\begin{array}{c}-0.041 \\
(0.010)^{* * *}\end{array}$ \\
\hline \# of children & $\begin{array}{c}0.001 \\
(0.000)^{* *}\end{array}$ & $\begin{array}{c}-0.002 \\
(0.001)\end{array}$ & $\begin{array}{c}0.001 \\
(0.000)^{* *}\end{array}$ & $\begin{array}{c}-0.002 \\
(0.001)\end{array}$ \\
\hline $\begin{array}{l}\text { Pseudo R2 } \\
N\end{array}$ & $\begin{array}{c}0.22 \\
49,012\end{array}$ & $\begin{array}{c}0.10 \\
60,533\end{array}$ & $\begin{array}{c}0.22 \\
49,012\end{array}$ & $\begin{array}{c}0.10 \\
60,533\end{array}$ \\
\hline
\end{tabular}

Table 5: Marginal effects using the constructed indexes.

Note: The table shows marginal effects of sample-weighted probit regressions, st. errors are clustered at country-level, all specifications include year and country fixed effects, and additional control variables at region and country-level which are omitted from the table. The dependent variable is a dummy for the intention to migrate locally or internationally (see text for details). The first two specifications include 'wealth' and 'standard of living' in a linear form, the last two specifications include these variables and their squared values. 'Local amenities' and 'local security' capture satisfaction at the city/local level, while 'contentment with the country' and 'corruption' reflect individual's satisfaction with the country-level institutions/amenities, 'work' reflects satisfaction with the job, 'close networks' reflect close social ties (local and abroad) of the individual, while 'broad networks' are proxied by the $\log$ of share of individuals at the current location that intend to move locally and abroad. For further details and description of individual controls see Section 1 and Appendix $B$ for further details. The corresponding probit coefficients are presented in Table 10 


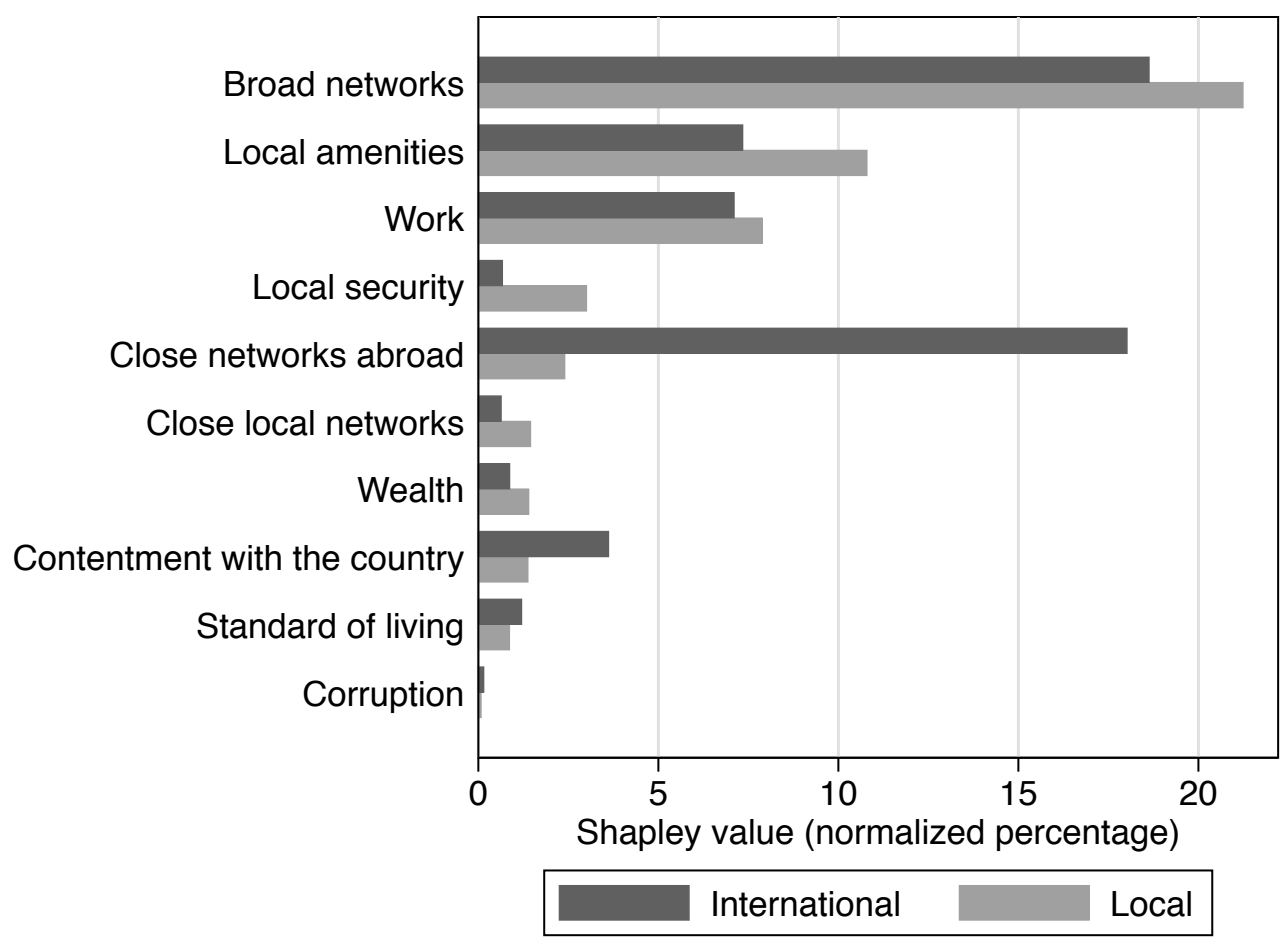

Figure 2: Shapley value decomposition.

Note: Broad networks bars represent broad local networks in regression of local migration intention and broad networks abroad in regression of international migration intention. Shapley values are normalized, the sum of these values for all variables including the fixed effects and other individual characteristics which are included in the regression but not on this graph is equal to 100 percent. The Shapley value for individual characteristics, country and year fixed effects are not included in the diagram. Source: own calculations using shapley2 program. 
of living is relatively low for migration intention.

\subsection{Robustness}

There are a number of potential issues with our identification. Empirical investigation of peer effects is challenging due to potential endogeneity problem. One needs to identify what drives the correlation between individual and peers' migration intentions (or decisions). In particular, there could be prior similarities between individuals, what Manski (1993) refers to as "correlated effects", that is individuals belonging to the same group tend to behave similarly as they face a common environment. If we do not control for these, we would have an endogeneity problem. In this section we undertake a series of robustness checks, first testing the robustness of results with principal components against using single questions. Then the following tests look at potential identification issues related to "correlated effects".

\subsubsection{Robustness check using individual questions from the survey}

As a robustness check we first run equation 7 replacing the constructed indexes with variables based on single questions from the survey. These variables do not capture as much underlying information from the data as the principal components, which are constructed from several questions each. Nevertheless, the coefficients are easier to interpret and this provides a robustness check on the results based on constructed indexes. An additional benefit compared to using principal components is that we are able to use a much larger sample due to better availability of the data for these variables.

These results, presented in Table 6, are in line with the results using indexes. The first two columns present results using the log of relative income, while the second two use the log of absolute income instead of the wealth and standard of living indexes. Having relatives/friends on whom the individual can count on abroad increases the probability of international migration intention by $2.6 \%$. On the other hand, stronger close local networks reduce the intention to migrate internationally, although the impact of close local social networks is much smaller in magnitude, corresponding to what we found using principal components.

Similarly to the results presented in Table 5, satisfaction with local amenities at the city level reduces the intention to migrate both locally and internationally, with the importance of local amenities being more pronounced for local migration intention. Those who are satisfied with the area where they live are $3 \%$ less likely to have international migration intention, and $13 \%$ less likely to have local migration intention than those who are dissatisfied.

\subsubsection{Robustness check using restricted close network}

There is a possibility that people who intend to migrate select friends who are already abroad or similarly were planning already to move when the friendship was formed resulting in a selection bias for our close social network variable abroad. In order to test the robustness of our result with respect to this issue, we run the regressions with a modified variable for measuring close 


\begin{tabular}{|c|c|c|c|c|}
\hline \multirow[b]{2}{*}{ Variables } & \multicolumn{2}{|c|}{ Using log of relative income } & \multicolumn{2}{|c|}{ Using log of absolute income } \\
\hline & internationally & $\begin{array}{l}\text { Intention } \\
\text { locally }\end{array}$ & $\begin{array}{l}\text { o migrate } \\
\text { internationally }\end{array}$ & locally \\
\hline Opportunity to make friends & $\begin{array}{c}-0.003 \\
(0.002)^{* *}\end{array}$ & $\begin{array}{c}-0.015 \\
(0.005)^{* * *}\end{array}$ & $\begin{array}{c}-0.003 \\
(0.002)^{* *}\end{array}$ & $\begin{array}{c}-0.015 \\
(0.005)^{* * *}\end{array}$ \\
\hline Have friends/family to count on abroad & $\begin{array}{c}0.026 \\
(0.001)^{* * *}\end{array}$ & $\begin{array}{c}0.030 \\
(0.003)^{* * *}\end{array}$ & $\begin{array}{c}0.026 \\
(0.001)^{* * *}\end{array}$ & $\begin{array}{c}0.030 \\
(0.003)^{* * *}\end{array}$ \\
\hline Broad networks abroad & $\begin{array}{c}0.017 \\
(0.001)^{* * *}\end{array}$ & & $\begin{array}{c}0.017 \\
(0.001)^{* * *}\end{array}$ & \\
\hline Broad local networks & & $\begin{array}{c}0.110 \\
(0.007)^{* * *}\end{array}$ & & $\begin{array}{c}0.111 \\
(0.007)^{* * *}\end{array}$ \\
\hline Satisfaction with the city/area & $\begin{array}{c}-0.029 \\
(0.002)^{* * *}\end{array}$ & $\begin{array}{c}-0.130 \\
(0.008)^{* * *}\end{array}$ & $\begin{array}{c}-0.029 \\
(0.002)^{* * *}\end{array}$ & $\begin{array}{c}-0.130 \\
(0.008)^{* * *}\end{array}$ \\
\hline Country economic condition (getting worse) & $\begin{array}{c}0.009 \\
(0.002)^{* * *}\end{array}$ & $\begin{array}{c}0.012 \\
(0.004)^{* * *}\end{array}$ & $\begin{array}{c}0.009 \\
(0.002)^{* * *}\end{array}$ & $\begin{array}{c}0.012 \\
(0.004)^{* * *}\end{array}$ \\
\hline Country economic condition (getting better) & $\begin{array}{l}-0.002 \\
(0.002)\end{array}$ & $\begin{array}{c}0.007 \\
(0.004)\end{array}$ & $\begin{array}{l}-0.002 \\
(0.002)\end{array}$ & $\begin{array}{c}0.007 \\
(0.004)\end{array}$ \\
\hline Part-time employment & $\begin{array}{c}-0.015 \\
(0.002)^{* * *}\end{array}$ & $\begin{array}{c}-0.047 \\
(0.008)^{* * *}\end{array}$ & $\begin{array}{c}-0.015 \\
(0.002)^{* * *}\end{array}$ & $\begin{array}{c}-0.046 \\
(0.008) * * *\end{array}$ \\
\hline Full-time employment & $\begin{array}{c}-0.012 \\
(0.002)^{* * *}\end{array}$ & $\begin{array}{c}-0.041 \\
(0.007)^{* * *}\end{array}$ & $\begin{array}{c}-0.012 \\
(0.002)^{* * *}\end{array}$ & $\begin{array}{c}-0.040 \\
(0.007)^{* * *}\end{array}$ \\
\hline Log (rel.) income & $\begin{array}{c}0.001 \\
(0.001)^{* *}\end{array}$ & $\begin{array}{c}0.003 \\
(0.002)^{*}\end{array}$ & & \\
\hline Log (abs.) income & & & $\begin{array}{c}0.001 \\
(0.001)\end{array}$ & $\begin{array}{c}0.001 \\
(0.002)\end{array}$ \\
\hline Married & $\begin{array}{c}-0.007 \\
(0.001)^{* * *}\end{array}$ & $\begin{array}{c}-0.018 \\
(0.003)^{* * *}\end{array}$ & $\begin{array}{c}-0.007 \\
(0.001)^{* * *}\end{array}$ & $\begin{array}{c}-0.018 \\
(0.003)^{* * *}\end{array}$ \\
\hline Age & $\begin{array}{c}-0.001 \\
(0.000)^{* * *}\end{array}$ & $\begin{array}{c}-0.002 \\
(0.000)^{* * *}\end{array}$ & $\begin{array}{c}-0.001 \\
(0.000)^{* * *}\end{array}$ & $\begin{array}{c}-0.002 \\
(0.000)^{* * *}\end{array}$ \\
\hline Education (medium) & $\begin{array}{c}0.005 \\
(0.001)^{* * *}\end{array}$ & $\begin{array}{c}0.018 \\
(0.003)^{* * *}\end{array}$ & $\begin{array}{c}0.005 \\
(0.001)^{* * *}\end{array}$ & $\begin{array}{c}0.018 \\
(0.003)^{* * *}\end{array}$ \\
\hline Education (high) & $\begin{array}{c}0.012 \\
(0.002)^{* * *}\end{array}$ & $\begin{array}{c}0.039 \\
(0.005)^{* * *}\end{array}$ & $\begin{array}{c}0.012 \\
(0.002)^{* * *}\end{array}$ & $\begin{array}{c}0.042 \\
(0.005)^{* * *}\end{array}$ \\
\hline Female & $\begin{array}{c}-0.007 \\
(0.001)^{* * *}\end{array}$ & $\begin{array}{c}-0.008 \\
(0.003)^{* *}\end{array}$ & $\begin{array}{c}-0.007 \\
(0.001)^{* * *}\end{array}$ & $\begin{array}{c}-0.008 \\
(0.003)^{* *}\end{array}$ \\
\hline Large city & $\begin{array}{c}0.006 \\
(0.002)^{* * *}\end{array}$ & $\begin{array}{c}0.014 \\
(0.004)^{* * *}\end{array}$ & $\begin{array}{c}0.006 \\
(0.002)^{* * *}\end{array}$ & $\begin{array}{c}0.014 \\
(0.004)^{* * *}\end{array}$ \\
\hline Healthy & $\begin{array}{c}-0.005 \\
(0.001)^{* * *}\end{array}$ & $\begin{array}{c}-0.022 \\
(0.005)^{* * *}\end{array}$ & $\begin{array}{c}-0.005 \\
(0.001)^{* * *}\end{array}$ & $\begin{array}{c}-0.022 \\
(0.005)^{* * *}\end{array}$ \\
\hline \# of children & $\begin{array}{c}0.000 \\
(0.000)\end{array}$ & $\begin{array}{l}-0.001 \\
(0.001)\end{array}$ & $\begin{array}{c}0.000 \\
(0.000)\end{array}$ & $\begin{array}{l}-0.001 \\
(0.001)\end{array}$ \\
\hline Pseudo R2 & 0.24 & 0.11 & 0.24 & 0.11 \\
\hline$N$ & 141,073 & 167,730 & 141,073 & 167,730 \\
\hline
\end{tabular}

$* p<0.1 ; * * p<0.05 ; * * * p<0.01$

Table 6: Regressions with single questions instead of principal components.

Note: The table above shows marginal effects of sample-weighted probit regressions, standard errors are clustered at country-level and additional control variables at region and country-level which are omitted from the table. These specifications include squared value of the corresponding measure of income (i.e. log of either absolute or relative income), year and country fixed effects which are omitted from the table. The dependent variable is an indicator for intention to move away from the current location internationally or locally. The variables used are described in Section 4 . 
social networks abroad. Instead of including close friends and family members, the question we use asks whether any household or family members live or have lived abroad in the past five years. This limits the abroad network to family members where the selection issue is unlikely, since while friends can be chosen by the individual, family is given. The sample becomes significantly smaller and some control variables loose significance, nevertheless the results on our main variable of interests remain very similar. Thus the findings confirm our previous results, see Table 18 in Appendix A.

\subsubsection{Robustness check using IV regressions}

There could be factors which we don't control for, but which simultaneously influence the share of people who intend to migrate from a country (broad networks) and the individual's intention to migrate. Similarly, there could be omitted factors which simultaneously influence the individuals' close social networks and the individuals' own intention to migrate. In order to establish causality, we run instrumental variable regressions. We have potentially two variables which are endogenous when determining international migration intentions, close and broad social networks abroad. Similarly, for local migration intentions broad networks can potentially be endogenous, being influenced by similar factors as individual intention for which we might not be controlling for.

Close social network abroad of an individual is composed of friends and family members who most likely lived in close vicinity, in the same region as the individual before going abroad. The size of the close network abroad will be bigger the more friends and family members migrated abroad, which should be highly correlated with factors driving migration decisions. From our data we can calculate the average perception of factors driving migration decisions at regional-level. How people perceive local amenities or the average income in a region are important factors influencing migration decisions. As such, we will use the region-level average satisfaction of the city and the region-level average of relative income as instruments for close networks. For both, we use two year lags of these variables. Similarly, as instrument for broad social networks abroad (which is proxied by the share people with same nationality intending to migrate abroad) we use the country level average perception of economic conditions, again with two-year lag.

In our regressions examining the drivers of local migration intentions, similarly to international migration intentions, there is a possibility that broad local networks (share of same nationals moving within the country) will be endogenous. We instrument for broad local networks with country-level average perception of local amenities (city safety, housing, and healthcare). These factors are likely to influence peers' migration intentions within the country.23

Given the use of lags, we use the single question specification instead of the principal components for the IV regressions, as using principal components would result in a reduction in sample size limiting our ability to employ country-specific fixed effects. Nevertheless as a

\footnotetext{
${ }^{23}$ The results with other potential instruments, including satisfaction with availability of healthcare, housing and roads, are similar and available upon request.
} 
robustness we also run regressions with principal components, where results are similar, with close networks being significant only at ten percent.

Results are presented in Table 7 with first stage results included in the Annex in Table 11. Table 7 presents two specifications for international migration intentions (first two columns) and one for domestic migration intentions (third column). In the first column, we instrument both for broad and close social networks abroad, while in the second column, we only use instruments for the close social networks abroad and use country-year fixed effects instead of broad social networks abroad. In the third column, instruments are used for broad local networks in determining domestic migration intentions.

The results on most of our control variables remain very similar to the results presented without IV (although, with IV relative income becomes insignificant for international migration intentions). Close networks have a somewhat higher coefficient in the case of international migration intentions than in the results presented without IV, although close networks are only ten percent significant in the specification with country-year fixed effects (second column). Individuals with close networks abroad are 14-16\% more likely to migrate abroad than those without close friends or family abroad. Furthermore, broad networks also have a slightly higher coefficient than in the specification without IV. We find that both networks have a positive signficant impact on international migration intentions. In addition, for local migration intentions, results are very close to those presented in Table 6 where no instruments were used.

In order to better understand how different types of networks influence migration decisions, in the next two subsections we distinguish local and foreign social networks with and without remittances. We explore the importance of these different types of networks on migration intention of individuals with different income and education level. 


\begin{tabular}{|c|c|c|c|}
\hline & \multicolumn{3}{|c|}{ Intention to migrate } \\
\hline & international & international & local \\
\hline Opportunities to make friends & $\begin{array}{c}-0.007 \\
(0.002)^{* * *}\end{array}$ & $\begin{array}{c}-0.007 \\
(0.002)^{* * *}\end{array}$ & $\begin{array}{c}-0.016 \\
(0.003)^{* * *}\end{array}$ \\
\hline Have friends/family to count on abroad & $\begin{array}{c}0.144 \\
(0.068)^{* *}\end{array}$ & $\begin{array}{c}0.157 \\
(0.086)^{*}\end{array}$ & $\begin{array}{c}0.030 \\
(0.003)^{* * *}\end{array}$ \\
\hline Broad networks abroad & $\begin{array}{c}0.030 \\
(0.008)^{* * *}\end{array}$ & & \\
\hline Broad local networks & & & $\begin{array}{c}0.141 \\
(0.061)^{* *}\end{array}$ \\
\hline Satisfaction with the city/area & $\begin{array}{c}-0.034 \\
(0.002)^{* * *}\end{array}$ & $\begin{array}{c}-0.033 \\
(0.002)^{* * *}\end{array}$ & $\begin{array}{c}-0.143 \\
(0.003)^{* * *}\end{array}$ \\
\hline Country economic condition (getting worse) & $\begin{array}{c}0.010 \\
(0.002)^{* * *}\end{array}$ & $\begin{array}{c}0.010 \\
(0.002)^{* * *}\end{array}$ & $\begin{array}{c}0.014 \\
(0.003)^{* * *}\end{array}$ \\
\hline Country economic condition (getting better) & $\begin{array}{c}-0.010 \\
(0.003)^{* * *}\end{array}$ & $\begin{array}{c}-0.010 \\
(0.004)^{* *}\end{array}$ & $\begin{array}{c}0.007 \\
(0.003)^{* *}\end{array}$ \\
\hline Part-time employment & $\begin{array}{c}-0.021 \\
(0.003)^{* * *}\end{array}$ & $\begin{array}{c}-0.020 \\
(0.003)^{* * *}\end{array}$ & $\begin{array}{c}-0.060 \\
(0.005)^{* * *}\end{array}$ \\
\hline Full-time employment & $\begin{array}{c}-0.020 \\
(0.003)^{* * *}\end{array}$ & $\begin{array}{c}-0.019 \\
(0.003)^{* * *}\end{array}$ & $\begin{array}{c}-0.056 \\
(0.006)^{* * *}\end{array}$ \\
\hline Log (rel.) income & $\begin{array}{c}-0.005 \\
(0.004)\end{array}$ & $\begin{array}{c}-0.006 \\
(0.006)\end{array}$ & $\begin{array}{c}0.003 \\
(0.002)^{* *}\end{array}$ \\
\hline Married & $\begin{array}{c}-0.009 \\
(0.002)^{* * *}\end{array}$ & $\begin{array}{c}-0.008 \\
(0.002)^{* * *}\end{array}$ & $\begin{array}{c}-0.023 \\
(0.002)^{* * *}\end{array}$ \\
\hline Age & $\begin{array}{c}-0.000 \\
(0.000)^{* * *}\end{array}$ & $\begin{array}{c}-0.000 \\
(0.000)^{* * *}\end{array}$ & $\begin{array}{c}-0.002 \\
(0.000)^{* * *}\end{array}$ \\
\hline Education (medium) & $\begin{array}{c}0.003 \\
(0.003)\end{array}$ & $\begin{array}{c}0.002 \\
(0.004)\end{array}$ & $\begin{array}{c}0.018 \\
(0.003)^{* * *}\end{array}$ \\
\hline Education (high) & $\begin{array}{c}-0.001 \\
(0.007)\end{array}$ & $\begin{array}{c}-0.003 \\
(0.009)\end{array}$ & $\begin{array}{c}0.035 \\
(0.004)^{* * *}\end{array}$ \\
\hline Female & $\begin{array}{c}-0.010 \\
(0.001)^{* * *}\end{array}$ & $\begin{array}{c}-0.009 \\
(0.001)^{* * *}\end{array}$ & $\begin{array}{c}-0.007 \\
(0.002)^{* * *}\end{array}$ \\
\hline Large city & $\begin{array}{c}0.004 \\
(0.002)\end{array}$ & $\begin{array}{c}0.003 \\
(0.003)\end{array}$ & $\begin{array}{c}0.010 \\
(0.003)^{* * *}\end{array}$ \\
\hline Healthy & $\begin{array}{c}-0.004 \\
(0.001)^{* * *}\end{array}$ & $\begin{array}{c}-0.003 \\
(0.001)^{* *}\end{array}$ & $\begin{array}{c}-0.021 \\
(0.003)^{* * *}\end{array}$ \\
\hline \# of children & $\begin{array}{c}0.000 \\
(0.000)\end{array}$ & $\begin{array}{c}0.000 \\
(0.000)\end{array}$ & $\begin{array}{c}-0.001 \\
(0.001)\end{array}$ \\
\hline$N$ & 96,623 & 104,888 & 139,762 \\
\hline Underidentification test, p-value & 0.000 & 0.000 & 0.000 \\
\hline Weak identification test $\mathrm{F}$ stat & 9.626 & 9.098 & 806.777 \\
\hline
\end{tabular}

$* p<0.1 ; * * p<0.05 ; * * * p<0.01$

Table 7: IV regressions with single questions.

Note: The table above uses the following set of instruments: the first column — close networks abroad are instrumented with twoyear lags of regional-level satisfaction with the local city/area and relative income, while broad networks abroad are instrumented with two-year lag of country-level perception of change in the country economy; the second column uses the same instruments for close networks abroad and adds country-year fixed effects instead of broad networks abroad; the third column instruments for broad local networks with two-year lags of region-level average perception of safety in the city, satisfaction with housing and healthcare. See Tale 11 for first stage results. The dependent variable is an indicator for intention to move away from the current location internationally or locally. The variables used are described in Section 4 . 


\subsection{Intention to migrate and different types of networks}

In order to better understand how social networks play a role in influencing migration intention, in particular close social networks both abroad and in the current country, we split the sample by income and education level. First, we re-run our main specification on two sub-samples: one containing low- and medium-income individuals (belonging to $1-3^{r d}$ income quintiles in a given country), the other containing higher income individuals (belonging to $4-5^{\text {th }}$ income quintiles). Next, we divide the sample into low-, medium-, and high-education individuals.

We distinguish between close social networks abroad and home with and without remittances.24 One might expect that the channels through which social networks influence migration decisions might be different for individuals with different income levels. For example, having a close social network abroad which can help financially might be relatively more important for individuals with lower income level. This can be particularly important for those individuals for whom the cost of migration would be higher than their current wealth without the financial support of the social network. The wealthier the individual becomes, the less is the importance of the financial support to reach the threshold where the individual has sufficient resources to migrate. In addition, individuals with different educational level might be influenced differently by different types of networks in their decision to migrate. It could be that remittances from close networks abroad have a signalling role indicating that the senders are more likely to have a better paying job and therefore could help potential immigrants finding better jobs.25 However, these jobs are more likely to be available only for those with higher level of education.

Similarly, close local networks with and without financial aid can result in different push and pull factors for individuals with different level of income. There could also be complex channels through which these networks matter. It could be that individuals with higher level of income have close friends and family members relying on them financially, making a risky migration decision less likely. On the other hand, Munshi and Rosenzweig (2016) show that in India richer individuals belonging to higher income local networks (sub-caste networks) have more to lose in terms of financial security when moving.

Using the specification of Table 5 we distinguish social networks by whether they send remittances or not and split the sample by income in Table 8, and by education in Table 9 (full results are provided in Tables 16 and 17 in Appendix A).

We find that broad social networks are somewhat more important drivers of international migration intention for low-income (Table 8) and low-educated (Table 9) individuals than for high-income/higher-educated individuals. This is in line with the previous literature, for example McKenzie and Rapoport (2007) construct a model which shows that as the social network abroad (at the destination) grows and the migration costs fall, the low-income individuals are more likely to migrate. On the other hand, for local migration intention we do not find the

\footnotetext{
${ }^{24}$ For social networks abroad we do this by combining answers from two questions. The survey asks if there are close friends or relatives abroad and also asks if the individual receives remittances from abroad. Thus, if an individual answers with 'yes' to both questions we conclude that the individual has a close social network abroad which provides remittances. For social networks at home we interact our close local network variable measuring the strength of social networks at home with remittances received from people at home.

${ }^{25}$ See Chuang and Schechter (2015) for an overview of related literature.
} 


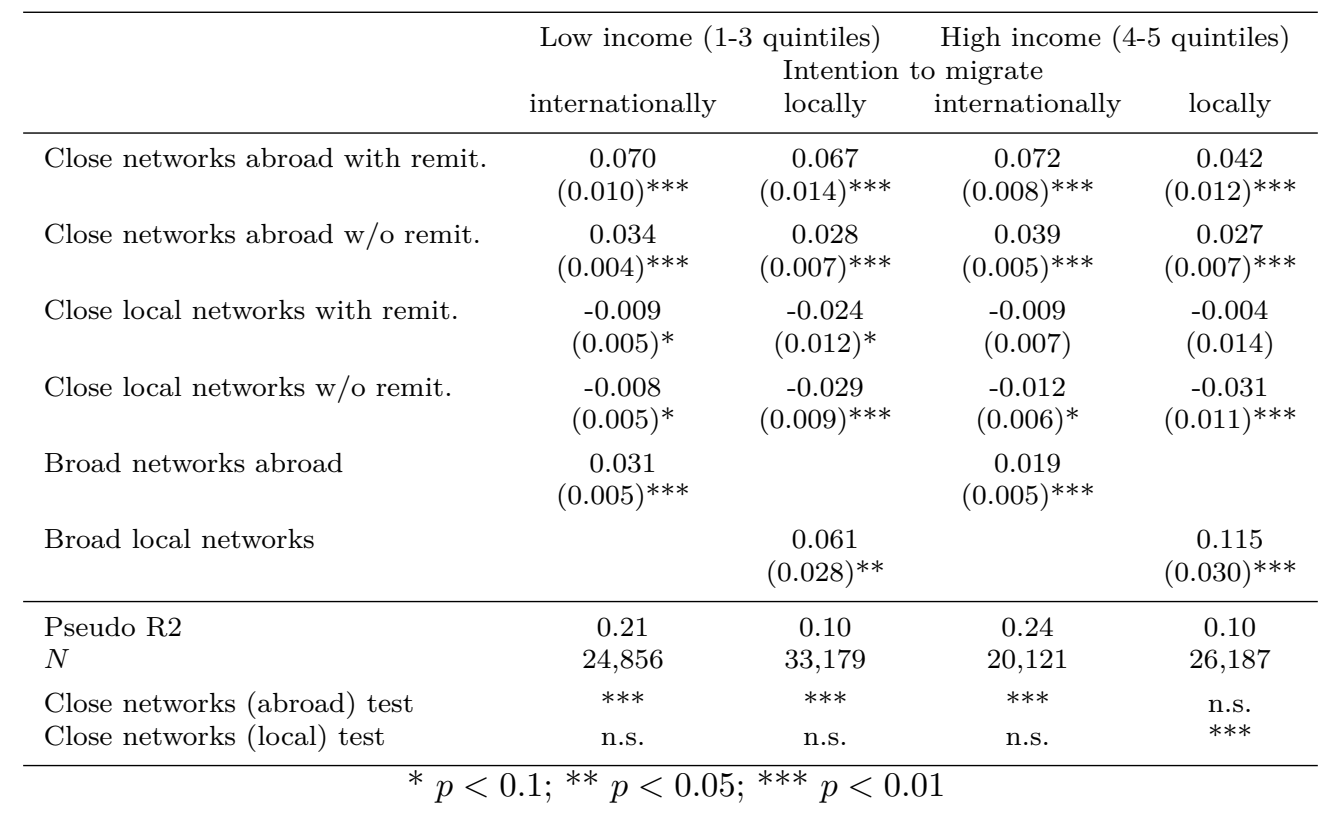

Table 8: Intention to migrate and income levels.

Note: The table shows marginal effects of sample-weighted probit regressions, st. errors are clustered at country-level, all specifications include year and country fixed effects and additional control variables at region and country-level which are omitted from the table. The dependent variable is a dummy for the intention to migrate locally or internationally (see text for details). 'Close networks' reflect close social ties (local and abroad) of the individual, while 'broad networks' are proxied by log of the share of individuals at the current location that would like to move locally and abroad. Close networks (abroad/local) test provides test results if coefficients of the two close networks are equal. Full regression results are presented in Table 16 and Table 12, Appendix A.

\begin{tabular}{|c|c|c|c|c|c|c|}
\hline & \multicolumn{2}{|c|}{ Low education } & \multicolumn{2}{|c|}{$\begin{array}{l}\text { Medium education } \\
\text { Intention to migrate }\end{array}$} & \multicolumn{2}{|c|}{ High education } \\
\hline & internationally & locally & internationally & locally i & internationally & locally \\
\hline Close networks abroad with remit. & $\begin{array}{c}0.059 \\
(0.010)^{* * *}\end{array}$ & $\begin{array}{c}0.038 \\
(0.015)^{* *}\end{array}$ & $\begin{array}{c}0.086 \\
(0.009)^{* * *}\end{array}$ & $\begin{array}{c}0.065 \\
(0.012)^{* * *}\end{array}$ & $\begin{array}{c}0.099 \\
(0.026)^{* * *}\end{array}$ & $\begin{array}{c}0.072 \\
(0.018)^{* * *}\end{array}$ \\
\hline Close networks abroad w/o remit. & $\begin{array}{c}0.035 \\
(0.004)^{* * *}\end{array}$ & $\begin{array}{c}0.012 \\
(0.008)\end{array}$ & $\begin{array}{c}0.041 \\
(0.005)^{* * *}\end{array}$ & $\begin{array}{c}0.039 \\
(0.006)^{* * *}\end{array}$ & $\begin{array}{c}0.036 \\
(0.007)^{* * *}\end{array}$ & $\begin{array}{c}0.031 \\
(0.010)^{* * *}\end{array}$ \\
\hline Close local networks with remit. & $\begin{array}{l}-0.012 \\
(0.007)^{*}\end{array}$ & $\begin{array}{l}-0.017 \\
(0.014)\end{array}$ & $\begin{array}{l}-0.010 \\
(0.006)\end{array}$ & $\begin{array}{c}-0.024 \\
(0.013)^{*}\end{array}$ & $\begin{array}{c}0.009 \\
(0.011)\end{array}$ & $\begin{array}{c}0.018 \\
(0.026)\end{array}$ \\
\hline Close local networks w/o remit. & $\begin{array}{c}-0.013 \\
(0.007)^{*}\end{array}$ & $\begin{array}{c}-0.028 \\
(0.009)^{* * *}\end{array}$ & $\begin{array}{c}-0.010 \\
(0.005)^{* *}\end{array}$ & $\begin{array}{c}-0.040 \\
(0.010)^{* * *}\end{array}$ & $\begin{array}{c}0.006 \\
(0.011)\end{array}$ & $\begin{array}{l}-0.007 \\
(0.025)\end{array}$ \\
\hline Broad networks abroad & $\begin{array}{c}0.030 \\
(0.010)^{* * *}\end{array}$ & & $\begin{array}{c}0.027 \\
(0.005)^{* * *}\end{array}$ & & $\begin{array}{c}0.021 \\
(0.015)\end{array}$ & \\
\hline Broad local networks & & $\begin{array}{c}0.091 \\
(0.037)^{* *}\end{array}$ & & $\begin{array}{c}0.102 \\
(0.036)^{* * *}\end{array}$ & & $\begin{array}{l}0.085 \\
(0.071)\end{array}$ \\
\hline Pseudo R2 & 0.23 & 0.08 & 0.23 & 0.12 & 0.24 & 0.11 \\
\hline$N$ & 16,282 & 21,555 & 21,632 & 29,341 & 5,922 & 8,590 \\
\hline Close networks (abroad) test & $* *$ & $*$ & $* * *$ & $* *$ & ** & ** \\
\hline Close networks (local) test & n.s. & n.s. & n.s. & * & n.s. & n.s. \\
\hline
\end{tabular}

Table 9: Intention to migrate and education levels.

Note: The table shows marginal effects of sample-weighted probit regressions, st. errors are clustered at country-level, all specifications include year and country fixed effects and additional control variables at region and country-level which are omitted from the table. The dependent variable is a dummy for the intention to migrate locally or internationally (see text for details). 'Close networks' reflect close social ties (local and abroad) of the individual, while 'broad networks' are proxied by log of the share of individuals at the current location that would like to move locally and abroad. Close networks (abroad/local) test provides test results if coefficients of the two close networks are equal. Full regression results are presented in Table 17 and Table 13, Appendix A. 
same result, local broad networks increase the probability of domestic migration intention of low-income individuals less than of high-income individuals. In addition, broad social networks do not have a significant impact for the most educated group of individuals in their intention to migrate internationally or locally.

Regarding close social networks abroad, both for high- and low-income individuals social networks with remittances increase migration intention significantly more than without financial assistance (for test results on whether coefficients are significantly different see the last two rows of the tables). Individuals with lower incomes are $7 \%$ more likely to intend to migrate internationally if they have close social networks from which they receive remittances, while those with close social networks without remittances are only $3.4 \%$ more likely to plan to migrate internationally. For those with higher incomes, the impact of close social networks abroad is quite similar, being $7 \%$ with and $3.9 \%$ without remittances. However, when the sample is split by education attainment, differences between the different groups emerge. Close social networks abroad with remittances matter significantly more than close social networks without remittances as the individuals become more educated. Social networks with remittances increase the likelihood of international migration intentions, with magnitude of this effect increasing with education level. The coefficient on close social network with remittances is about 2.9 times bigger than for close social networks without remittances for the highly educated individuals, about 1.6 times bigger for low-educated and about 2.1 times bigger for medium-educated individuals.

One explanation for these results is that remittances coming from close social networks abroad not only provide direct financial assistance, but also have a signalling function to those who intend to migrate internationally. Possibly, higher-educated individuals are more likely to be able to take up relatively higher-paying jobs, or expect to be able to do so. To these individuals, close social networks abroad with remittances send a signal that those sending the remittances are relatively richer or work in higher-paying jobs and are more likely to be able to eventually help finding/obtaining better-paying jobs (for further references examining the link between social networks and job search see Munshi, 2003; Comola and Mendola, 2015). On the other hand, those with only primary school level of education are unlikely to look for this kind of signal as they are unlikely to expect to be able to take up a higher-paying job, which typically would require higher skill levels. Networks sending remittances are relatively more important for all groups than networks without remittances, which indicates that these networks play a role in providing financial help to cover some costs of migrating. For high education group, remittances could also send a signal of potential help in finding better-paying jobs. 26

Close local networks with and without remittances on the other hand seem to play slightly different roles for lower- and higher-income individuals, while being less important than abroad networks in general. For lower-income individuals, both types of close local networks reduce the

\footnotetext{
${ }^{26}$ It should be noted however, that although our social network variable abroad always proxies close ties (family or close friends), it could be, that those networks with financial assistance foster more migration intention not because of financial facilitation but because those represent even closer ties.
} 
probability of both local and international migration intentions with no significant difference in the coefficients. Furthermore, for higher-income individuals, only those local networks have a signficant impact which do not involve financial assistance, decreasing the probability of international migration intention by $1.2 \%$ (with only $10 \%$ significance) and local migration intention by $3.1 \%$.

Close local social networks also have a somewhat different impact in case of different education levels. We find that having stronger social ties at home (most importantly without remittances) reduces the likelihood of the intention to migrate internationally or locally for low- and medium-educated individuals, but has no impact on those with high education level. Higher-educated individuals seem not to be constrained by local social networks. In addition, close local networks without remittances matter more across all income and education groups. These findings indicate that close local networks tend to influence more migration within the country and only marginally international migration. In addition, people are less likely to be influenced if they have a network from which they receive financial assistance. This could be because in networks from which they do not receive remittances they are more likely to have others relying on them, making migration more difficult.

\subsubsection{Robustness}

There is a possibility that those who plan to migrate, first decide that they want to migrate and then they request that close friends and family members abroad send remittances to cover expenses related to emigrating. If this is the case, we have a problem of reverse causality and we might be misinterpreting some of the results above. In order to check if this type of reverse causality is driving the results, we restrict the sample to those individuals who themselves send remittances. Presumably, if an individual sends remittances she is not in need of receiving remittances in order to cover the costs of migrating. Thus migration intentions are not likely to drive received remittances, so for this sub-sample reverse causality is unlikely. The question from the survey related to the individual sending remittances was not asked in all years and restricts us to year 2012 .

The main results on our social network variables hold with this sample restriction (see these results in Tables 14 and 15 in Appendix 27 . As before, there is no important difference between the relative importance of close networks abroad with and without remittances between highand low-income individuals (except for the low-income individuals with intention to migrate locally). In addition, as before, when looking at individuals with different education level, close networks abroad with remittances are relatively more important than without remittances in increasing the probability of migration intention for highly educated individuals than for those with lower levels of educations.

\footnotetext{
${ }^{27}$ These tables are based on specifications that include broad networks, we also tried country fixed effects specifications and the results are very similar
} 


\section{Conclusions}

Using a unique survey dataset, we explored the importance of different types of social networks together with individual perceptions of amenities at country and local level, and other individual characteristics in influencing the intention to migrate either locally or internationally. We find that social networks can explain a large share of the variation in these intentions. We distinguished between close social networks abroad and at home, with further distinction depending on whether they provide remittances or not, and we also controlled for broad networks (same-country residents with intention to migrate). We investigated the impact of these different networks on individuals with different income and education levels.

This analysis provides several interesting results. First, close and broad networks are shown to explain the largest share of variation in the probability of both international and local migration intentions. The robustness checks undertaken provide support to the causal direction from social networks to the intention to migrate. Close and broad social networks abroad explain almost a fifth of variation in international migration intention each. On the other hand, close networks at the current location reduce the likelihood of the intention to migrate both internationally and locally, albeit their importance is much lower, specially for international migration intention.

Second, when splitting the sample by income and education level of individuals, we find that while close networks abroad with remittances are more important than those without remittances for all groups, they are relatively more important for highly educated individuals. Social networks with remittances increase the likelihood of international migration intention almost 3 times more than social networks without remittances for highly educated individuals, while only about 1.6 times more in case of individuals with low education and about 2 times more for medium-educated individuals. These results indicate that close networks abroad which provide financial assistance possibly play a role in covering parts of migration costs, but additionally, for highly educated individuals also send a signal about potential assistance in finding better paying jobs.

Third, local social networks without remittances play a more important role in deterring local migration intentions than local networks with remittances, and close local networks do not influence significantly migration intentions of highly educated individuals.

\section{References}

Banerjee, Biswajit. 1983. "Social networks in the migration process: empirical evidence on chain migration in India". The Journal of Developing Areas 17 (2): 185-196.

Beine, Michel, Frédéric Docquier, and Çağlar Özden. 2011. "Diasporas". Symposium on Globalization and Brain Drain, Journal of Development Economics 95 (1): 30-41.

Beine, Michel, and Sara Salomone. 2012. "Network effects in international migration: education versus gender". The Scandinavian Journal of Economics 115 (2): 354-380. 
Bell, Martin, and Elin Charles-Edwards. 2013. "Cross-national comparisons of internal migration: an update of global patterns and trends". Technical paper, No.2013/1.

Boyd, Monica. 1989. "Family and Personal Networks in International Migration: Recent Developments and New Agendas". International Migration Review 23 (3): 638-670.

Brücker, Herbert, Stella Capuano, and Abdeslam Marfouk. 2013. "Education, gender and international migration: insights from a panel-dataset 1980-2010". Mimeo.

Calvo, Rocío, Yuhui Zheng, Santosh Kumar, Analia Olgiati, and Lisa Berkman. 2012. "Wellbeing and social capital on planet Earth: cross-national evidence from 142 countries". PloS One 7 (8): e42793.

Chen, Yong, and Stuart S. Rosenthal. 2008. "Local amenities and life-cycle migration: do people move for jobs or fun?" Journal of Urban Economics 64 (3): 519-537.

Chuang, Yating, and Laura Schechter. 2015. "Social Networks in Developing Countries". Annual Review of Resource Economics 7 (1).

Comola, Marherita, and Mariapia Mendola. 2015. "Formation of Migrant Networks".

Creighton, Mathew J. 2013. "The role of aspirations in domestic and international migration". The Social Science Journal 50 (1): 79-88.

De Simone, Gianfranco, and Miriam Manchin. 2012. "Outward migration and inward FDI: factor mobility between Eastern and Western Europe". Review of International Economics 20 (3): 600-615.

Docquier, Frédéric, Abdeslam Marfouk, Sara Salomone, and Khalid Sekkat. 2012. "Are skilled women more migratory than skilled men?" World Development 40 (2): 251-265.

Docquier, Frédéric, Giovanni Peri, and Ilse Ruyssen. 2014. "The Cross-country Determinants of Potential and Actual Migration". International Migration Review 48 (S1): S37-S99.

Docquier, Frédéric, and Hillel Rapoport. 2012. "Globalization, Brain Drain, and Development". Journal of Economic Literature 50 (3): 681-730.

Donato, Katharine M., Jorge Durand, and Douglas S. Massey. 1992. "Changing Conditions in the US Labor Market: Effects of the Immigration Reform and Control Act of 1986". Population Research and Policy Review 11 (2): 93-115.

Dustmann, Christian, and Anna Okatenko. 2014. "Out-migration, wealth constraints, and the quality of local amenities". Journal of Development Economics 110:52-63.

Esipova, Neli, Julie Ray, and Anita Pugliese. 2011. "Gallup World Poll: the many faces of global migration". IOM Migration Research Series, No. 43.

Flores-Yeffal, Nadia Y., and Maria Aysa-Lastra. 2011. "Place of Origin, Types of Ties, and Support Networks in Mexico-US Migration". Rural Sociology 4 (76): 481-510.

Gallup. 2012. "Worldwide research methodology and codebook".

Hatcher, Larry, and Norm O'Rourke. 2014. A step-by-step approach to using SAS for factor analysis and structural equation modeling. SAS Institute. 
Hatton, Timothy J., and Jeffrey G. Williamson. 2002. "What fundamentals drive world migration?" NBER working paper 9159.

Javorcik, Beata S, Çağlar Özden, Mariana Spatareanu, and Cristina Neagu. 2011. "Migrant networks and foreign direct investment". Journal of Development Economics 94 (2): 231241.

Kerr, William R. 2008. "Ethnic scientific communities and international technology diffusion". The Review of Economics and Statistics 90 (3): 518-537.

King, Russell, and Ronald Skeldon. 2010. “"Mind the Gap!” Integrating Approaches to Internal and International Migration". Journal of Ethnic and Migration Studies 36 (10): 1619-1646.

Knapp, Thomas A., and Philip E. Gravest. 1989. "On the role of amenities in models of migration and regional development". Journal of Regional Science 29 (1): 71-87.

Kolenikov, Stas, and Gustavo Angeles. 2004. The use of discrete data in principal component analysis with applications to socio-economic indices. Tech. rep. MEASURE Working paper No. WP-04-85.

Lovo, Stefania. 2013. "Tell Me Where You Would Like to Go and I Tell You Why - Potential Migration and Subjective Well-Being". Mimeo, http://papers.ssrn.com/sol3/papers. cfm?abstract_id=2237537.

Manski, Charles F. 1993. "Identification of endogenous social effects: The reflection problem". The review of economic studies 60 (3): 531-542.

Massey, Arango J. Hugo G. Kouaouci A. Pellegrino A. Taylor J.E., D.S. 1993. "Theories of international migration: review and appraisal. Population and Development". Population and Development Review 3 (19): 431-466.

Mayda, Anna Maria. 2010. "International migration: a panel data analysis of the determinants of bilateral flows". Journal of Population Economics 23 (4): 1249-1274.

McKenzie, David, and Hillel Rapoport. 2007. "Network effects and the dynamics of migration and inequality: theory and evidence from Mexico". Journal of Development Economics 84 (1): $1-24$.

— . 2010. "Self-Selection Patterns in Mexico-U.S. Migration: The Role of Migration Networks". Review of Economics and Statistics 92 (4): 811-821.

Mendola, Mariapia. 2008. "Migration and technological change in rural households: complements or substitutes?" Journal of Development Economics 85 (1): 150-175.

Mulligan, Gordon, John Carruthers, and Meagan Cahill. 2004. "Urban quality of life and public policy: A survey". In Urban Dynamics and Growth: Advances in Urban Economics, 266:729802.

Munshi, Kaivan. 2014a. "Community networks and migration". In The Oxford handbook of the economics of networks.

- . 2014b. "Community Networks and the Process of Development". Journal of Economic Perspectives 28 (4): 49-76. 
— . 2003. "Networks in the Modern Economy: Mexican Migrants in the U. S. Labor Market". The Quarterly Journal of Economics 118 (2): 549-599.

Munshi, Kaivan, and Mark Rosenzweig. 2016. "Networks and Misallocation: Insurance, Migration, and the Rural-Urban Wage Gap". American Economic Review 106 (1): 46-98.

Niedomysl, Thomas, and Høgni Kalsø Hansen. 2010. "What matters more for the decision to move: jobs versus amenities". Environment and planning. A 42 (7): 1636-1649.

Olgiati, Analia, Rocío Calvo, and Lisa Berkman. 2013. "Are migrants going up a blind alley? Economic migration and life satisfaction around the world: cross-national evidence from Europe, North America and Australia". Social Indicators Research 114 (2): 383-404.

Ortega, Francesc, and Giovanni Peri. 2009. "The causes and effects of international migrations: Evidence from OECD countries 1980-2005”. NBER working paper 14833.

Rubalcava, Luis N, Graciela M Teruel, Duncan Thomas, and Noreen Goldman. 2008. "The healthy migrant effect: new findings from the Mexican Family Life Survey". Journal Information 98 (1).

Scott, Allen J. 2010. "Jobs or amenities? Destination choices of migrant engineers in the USA". Papers in Regional Science 89 (1): 43-63.

Shorrocks, Anthony F. 1982. "Inequality decomposition by factor components". Econometrica 50 (1): 193-211.

Sjaastad, Larry A. 1962. "Costs And Returns of Human Migration". Journal of Political Economy 70 (5): 80-93.

Takenaka, Ayumi, and Karen A Pren. 2010. "Determinants of emigration: comparing migrants' selectivity from Peru and Mexico". The ANNALS of the American Academy of Political and Social Science 630 (1): 178-193.

UNDP. 2009. Human development report. Overcoming barriers: human mobility and development.

van Dalen, Hendrik P., and Kène Henkens. 2008. "Emigration intentions: mere words or true plans? Explaining international migration intentions and behavior". Discussion paper, http: //ideas.repec.org/p/dgr/kubcen/200860.html.

Zavodny, Madeline. 1997. "Welfare and the locational choices of new immigrants". Economic Review-Federal Reserve Bank of Dallas, no. QII: 2-10. 


\section{A Appendix: supporting tables}

\begin{tabular}{|c|c|c|c|c|}
\hline & \multicolumn{2}{|c|}{ Linear specification } & \multicolumn{2}{|c|}{ Non-linear specification } \\
\hline & & Intention & & \\
\hline & internationally & locally & internationally & locally \\
\hline Close local networks & $\begin{array}{c}-0.146 \\
(0.071)^{* *}\end{array}$ & $\begin{array}{c}-0.115 \\
(0.031)^{* * *}\end{array}$ & $\begin{array}{c}-0.147 \\
(0.071)^{* *}\end{array}$ & $\begin{array}{c}-0.118 \\
(0.031)^{* * *}\end{array}$ \\
\hline Close networks abroad & $\begin{array}{c}0.603 \\
(0.041)^{* * *}\end{array}$ & $\begin{array}{c}0.147 \\
(0.020)^{* * *}\end{array}$ & $\begin{array}{c}0.602 \\
(0.041)^{* * *}\end{array}$ & $\begin{array}{c}0.147 \\
(0.020)^{* * *}\end{array}$ \\
\hline Broad networks abroad & $\begin{array}{c}0.447 \\
(0.050)^{* * *}\end{array}$ & & $\begin{array}{c}0.448 \\
(0.050)^{* * *}\end{array}$ & \\
\hline Broad local networks & & $\begin{array}{c}0.463 \\
(0.083)^{* * *}\end{array}$ & & $\begin{array}{c}0.458 \\
(0.083)^{* * *}\end{array}$ \\
\hline Local amenities & $\begin{array}{c}-0.569 \\
(0.078)^{* * *}\end{array}$ & $\begin{array}{c}-0.470 \\
(0.043)^{* * *}\end{array}$ & $\begin{array}{c}-0.570 \\
(0.078)^{* * *}\end{array}$ & $\begin{array}{c}-0.473 \\
(0.043)^{* * *}\end{array}$ \\
\hline Local security & $\begin{array}{c}-0.384 \\
(0.090)^{* * *}\end{array}$ & $\begin{array}{c}-0.408 \\
(0.049)^{* * *}\end{array}$ & $\begin{array}{c}-0.383 \\
(0.090)^{* * *}\end{array}$ & $\begin{array}{c}-0.407 \\
(0.050)^{* * *}\end{array}$ \\
\hline Contentment with the country & $\begin{array}{c}-0.374 \\
(0.089)^{* * *}\end{array}$ & $\begin{array}{l}-0.057 \\
(0.053)\end{array}$ & $\begin{array}{c}-0.374 \\
(0.088)^{* * *}\end{array}$ & $\begin{array}{l}-0.056 \\
(0.053)\end{array}$ \\
\hline Corruption & $\begin{array}{c}-0.204 \\
(0.113)^{*}\end{array}$ & $\begin{array}{l}-0.045 \\
(0.079)\end{array}$ & $\begin{array}{c}-0.202 \\
(0.112)^{*}\end{array}$ & $\begin{array}{l}-0.044 \\
(0.078)\end{array}$ \\
\hline Work & $\begin{array}{c}-0.344 \\
(0.065)^{* * *}\end{array}$ & $\begin{array}{c}-0.265 \\
(0.039)^{* * *}\end{array}$ & $\begin{array}{c}-0.342 \\
(0.065)^{* * *}\end{array}$ & $\begin{array}{c}-0.261 \\
(0.039)^{* * *}\end{array}$ \\
\hline Wealth & $\begin{array}{c}0.200 \\
(0.110)^{*}\end{array}$ & $\begin{array}{c}0.070 \\
(0.088)\end{array}$ & $\begin{array}{c}0.497 \\
(0.363)\end{array}$ & $\begin{array}{c}0.662 \\
(0.218)^{* * *}\end{array}$ \\
\hline Standard of living & $\begin{array}{c}-0.465 \\
(0.160)^{* * *}\end{array}$ & $\begin{array}{c}-0.217 \\
(0.071)^{* * *}\end{array}$ & $\begin{array}{l}-0.210 \\
(0.444)\end{array}$ & $\begin{array}{l}-0.169 \\
(0.342)\end{array}$ \\
\hline Wealth sq. & & & $\begin{array}{c}-0.292 \\
(0.348)\end{array}$ & $\begin{array}{c}-0.558 \\
(0.174)^{* * *}\end{array}$ \\
\hline Standard of living sq. & & & $\begin{array}{l}-0.250 \\
(0.499)\end{array}$ & $\begin{array}{l}-0.037 \\
(0.344)\end{array}$ \\
\hline Married & $\begin{array}{c}-0.209 \\
(0.042)^{* * *}\end{array}$ & $\begin{array}{c}-0.127 \\
(0.023)^{* * *}\end{array}$ & $\begin{array}{c}-0.209 \\
(0.042)^{* * *}\end{array}$ & $\begin{array}{c}-0.127 \\
(0.023)^{* * *}\end{array}$ \\
\hline Age & $\begin{array}{c}-0.015 \\
(0.002)^{* * *}\end{array}$ & $\begin{array}{c}-0.014 \\
(0.001)^{* * *}\end{array}$ & $\begin{array}{c}-0.015 \\
(0.002)^{* * *}\end{array}$ & $\begin{array}{c}-0.014 \\
(0.001)^{* * *}\end{array}$ \\
\hline Education (medium) & $\begin{array}{c}0.103 \\
(0.055)^{*}\end{array}$ & $\begin{array}{c}0.094 \\
(0.024)^{* * *}\end{array}$ & $\begin{array}{c}0.102 \\
(0.054)^{*}\end{array}$ & $\begin{array}{c}0.093 \\
(0.024)^{* * *}\end{array}$ \\
\hline Education (high) & $\begin{array}{c}0.193 \\
(0.070)^{* * *}\end{array}$ & $\begin{array}{c}0.179 \\
(0.029)^{* * *}\end{array}$ & $\begin{array}{c}0.199 \\
(0.071)^{* * *}\end{array}$ & $\begin{array}{c}0.194 \\
(0.029)^{* * *}\end{array}$ \\
\hline Female & $\begin{array}{c}-0.197 \\
(0.041)^{* * *}\end{array}$ & $\begin{array}{c}-0.075 \\
(0.025)^{* * *}\end{array}$ & $\begin{array}{c}-0.196 \\
(0.041)^{* * *}\end{array}$ & $\begin{array}{c}-0.075 \\
(0.025)^{* * *}\end{array}$ \\
\hline Large city & $\begin{array}{c}0.128 \\
(0.055)^{* *}\end{array}$ & $\begin{array}{c}0.034 \\
(0.026)\end{array}$ & $\begin{array}{c}0.128 \\
(0.055)^{* *}\end{array}$ & $\begin{array}{c}0.035 \\
(0.025)\end{array}$ \\
\hline Healthy & $\begin{array}{c}-0.153 \\
(0.043)^{* * *}\end{array}$ & $\begin{array}{c}-0.176 \\
(0.041)^{* * *}\end{array}$ & $\begin{array}{c}-0.153 \\
(0.044)^{* * *}\end{array}$ & $\begin{array}{c}-0.175 \\
(0.041)^{* * *}\end{array}$ \\
\hline \# of children & $\begin{array}{c}0.019 \\
(0.009)^{* *}\end{array}$ & $\begin{array}{l}-0.007 \\
(0.005)\end{array}$ & $\begin{array}{c}0.018 \\
(0.009)^{* *}\end{array}$ & $\begin{array}{l}-0.007 \\
(0.005)\end{array}$ \\
\hline $\begin{array}{l}\text { Pseudo R2 } \\
N\end{array}$ & $\begin{array}{c}0.22 \\
49,012\end{array}$ & $\begin{array}{c}0.10 \\
60,533\end{array}$ & $\begin{array}{c}0.22 \\
49,012\end{array}$ & $\begin{array}{c}0.10 \\
60,533\end{array}$ \\
\hline
\end{tabular}

Table 10: Probit regression coefficients for specification in Table 5.

Note: The table shows probit coefficients of sample-weighted regressions, st. errors are clustered at country-level, all specifications include year and country fixed effects and additional control variables at region and country-level which are omitted from the table. The dependent variable is a dummy for the intention to migrate locally or internationally (see text for details). The first two specifications include 'wealth' and 'standard of living' in a linear form, the last two specifications include these variables and their squared values. 'Local amenities' and 'local security' capture satisfaction at the city/local level, while 'contentment with the country' and 'corruption' reflect individual's satisfaction with the country-level institutions/amenities, 'work' reflects satisfaction with the job, 'close networks' reflect social networks (local and abroad) of the individual, while 'broad networks' are proxied by log of the share of other individuals at the current location that would like to move locally and abroad. For further details and description of individual controls see Section 4 . All of the indexes are principal components capturing information from the underlying variables - see Appendix B for further details. 


\begin{tabular}{|c|c|c|c|c|}
\hline & international & $\begin{array}{r}\text { Intention } \\
\text { international } \\
\text { Instruments }\end{array}$ & $\begin{array}{l}\text { o migrate } \\
\text { international } \\
\text { or networks }\end{array}$ & \\
\hline & close abroad & broad abroad & close abroad & broad local \\
\hline Region avg city satisfaction, 2-year lag & $\begin{array}{c}-0.035 \\
(0.015)^{* *}\end{array}$ & $\begin{array}{c}0.047 \\
(0.013)^{* * *}\end{array}$ & $\begin{array}{c}-0.040 \\
(0.015)^{* * *}\end{array}$ & \\
\hline Region avg rel income, 2-year lag & $\begin{array}{c}0.025 \\
(0.006)^{* * *}\end{array}$ & $\begin{array}{c}0.089 \\
(0.005)^{* * *}\end{array}$ & $\begin{array}{c}0.019 \\
(0.005)^{* * *}\end{array}$ & \\
\hline Country avg perception of economy, 2-year lag & $\begin{array}{c}0.059 \\
(0.016)^{* * *}\end{array}$ & $\begin{array}{c}-0.789 \\
(0.025)^{* * *}\end{array}$ & & \\
\hline Opportunities to make friends & $\begin{array}{c}0.026 \\
(0.004)^{* * *}\end{array}$ & $\begin{array}{c}-0.000 \\
(0.003)\end{array}$ & $\begin{array}{c}0.024 \\
(0.004)^{* * *}\end{array}$ & $\begin{array}{c}-0.011 \\
(0.001)^{* * *}\end{array}$ \\
\hline Satisfaction with the city/area & $\begin{array}{c}0.017 \\
(0.004)^{* * *}\end{array}$ & $\begin{array}{c}-0.002 \\
(0.003)\end{array}$ & $\begin{array}{c}0.016 \\
(0.004)^{* * *}\end{array}$ & $\begin{array}{c}-0.002 \\
(0.001)^{* *}\end{array}$ \\
\hline Country economic condition (getting worse) & $\begin{array}{c}0.010 \\
(0.004)^{* *}\end{array}$ & $\begin{array}{c}-0.003 \\
(0.003)\end{array}$ & $\begin{array}{c}0.009 \\
(0.004)^{* *}\end{array}$ & $\begin{array}{c}0.005 \\
(0.001)^{* * *}\end{array}$ \\
\hline Country economic condition (getting better) & $\begin{array}{c}0.046 \\
(0.004)^{* * *}\end{array}$ & $\begin{array}{c}0.009 \\
(0.003)^{* * *}\end{array}$ & $\begin{array}{c}0.045 \\
(0.004)^{* * *}\end{array}$ & $\begin{array}{c}0.011 \\
(0.001)^{* * *}\end{array}$ \\
\hline Part-time employment & $\begin{array}{c}-0.007 \\
(0.007)\end{array}$ & $\begin{array}{c}-0.002 \\
(0.005)\end{array}$ & $\begin{array}{c}-0.007 \\
(0.007)\end{array}$ & $\begin{array}{c}0.002 \\
(0.001)\end{array}$ \\
\hline Full-time employment & $\begin{array}{c}-0.003 \\
(0.007)\end{array}$ & $\begin{array}{c}-0.002 \\
(0.005)\end{array}$ & $\begin{array}{c}-0.003 \\
(0.007)\end{array}$ & $\begin{array}{c}-0.002 \\
(0.001)\end{array}$ \\
\hline Log (rel.) income & $\begin{array}{c}0.064 \\
(0.002)^{* * *}\end{array}$ & $\begin{array}{c}-0.010 \\
(0.002)^{* * *}\end{array}$ & $\begin{array}{c}0.062 \\
(0.002)^{* * *}\end{array}$ & $\begin{array}{c}0.000 \\
(0.000)\end{array}$ \\
\hline Married & $\begin{array}{c}-0.010 \\
(0.004)^{* * *}\end{array}$ & $\begin{array}{c}0.000 \\
(0.003)\end{array}$ & $\begin{array}{c}-0.009 \\
(0.003)^{* * *}\end{array}$ & $\begin{array}{c}0.000 \\
(0.001)\end{array}$ \\
\hline Age & $\begin{array}{c}-0.000 \\
(0.000)\end{array}$ & $\begin{array}{c}0.000 \\
(0.000)\end{array}$ & $\begin{array}{c}-0.000 \\
(0.000)^{* *}\end{array}$ & $\begin{array}{c}-0.000 \\
(0.000)\end{array}$ \\
\hline Education (medium) & $\begin{array}{c}0.042 \\
(0.004)^{* * *}\end{array}$ & $\begin{array}{c}0.013 \\
(0.003)^{* * *}\end{array}$ & $\begin{array}{c}0.040 \\
(0.004)^{* * *}\end{array}$ & $\begin{array}{c}0.000 \\
(0.001)\end{array}$ \\
\hline Education (high) & $\begin{array}{c}0.096 \\
(0.006)^{* * *}\end{array}$ & $\begin{array}{c}0.006 \\
(0.004)\end{array}$ & $\begin{array}{c}0.098 \\
(0.006)^{* * *}\end{array}$ & $\begin{array}{c}0.003 \\
(0.001)^{* *}\end{array}$ \\
\hline Female & $\begin{array}{c}0.009 \\
(0.003)^{* * *}\end{array}$ & $\begin{array}{c}-0.001 \\
(0.003)\end{array}$ & $\begin{array}{c}0.008 \\
(0.003)^{* *}\end{array}$ & $\begin{array}{c}-0.001 \\
(0.001)\end{array}$ \\
\hline Large city & $\begin{array}{c}0.025 \\
(0.004)^{* * *}\end{array}$ & $\begin{array}{c}-0.017 \\
(0.003)^{* * *}\end{array}$ & $\begin{array}{c}0.026 \\
(0.004)^{* * *}\end{array}$ & $\begin{array}{c}0.004 \\
(0.001)^{* * *}\end{array}$ \\
\hline Healthy & $\begin{array}{c}-0.003 \\
(0.004)\end{array}$ & $\begin{array}{c}-0.001 \\
(0.003)\end{array}$ & $\begin{array}{c}-0.006 \\
(0.004)\end{array}$ & $\begin{array}{c}-0.007 \\
(0.001)^{* * *}\end{array}$ \\
\hline \# of children & $\begin{array}{c}-0.003 \\
(0.001)^{* * *}\end{array}$ & $\begin{array}{c}0.001 \\
(0.001)\end{array}$ & $\begin{array}{c}-0.003 \\
(0.001)^{* *}\end{array}$ & $\begin{array}{c}0.002 \\
(0.000)^{* * *}\end{array}$ \\
\hline Country avg city safety, 2-year lag & & & & $\begin{array}{c}0.395 \\
(0.016)^{* * *}\end{array}$ \\
\hline Country avg city housing, 2-year lag & & & & $\begin{array}{c}0.173 \\
(0.016)^{* * *}\end{array}$ \\
\hline Country avg city healthcare, 2-year lag & & & & $\begin{array}{c}0.152 \\
(0.020)^{* * *}\end{array}$ \\
\hline$N$ & 96,623 & 96,623 & 104,888 & 139,762 \\
\hline
\end{tabular}

$* p<0.1 ; * * p<0.05 ; * * * p<0.01$

Table 11: IV regressions with single questions (first stage).

Note: The table shows first-stage results for specifications in Table ??. The instruments used in the first and second columns close networks abroad are instrumented with two-year lags of regional-level satisfaction with the local city/area and relative income, while broad networks abroad are instrumented with two-year lag of country-level perception of change in the country economy; the third column uses the same instruments for close networks abroad and adds country-year fixed effects instead of broad networks abroad; the fourth column instruments for broad local networks with two-year lags of region-level average perception of safety in the city, satisfaction with housing and healthcare. The dependent variable is an indicator for intention to move away from the current location internationally or locally. The variables used are described in Section 1 . 


\begin{tabular}{|c|c|c|c|c|}
\hline & \multicolumn{2}{|c|}{ Low income (1-3 quintiles) } & \multicolumn{2}{|c|}{ High income (4-5 quintiles) } \\
\hline & & $\begin{array}{l}\text { Intention } \\
\text { locally }\end{array}$ & $\begin{array}{l}\text { to migrate } \\
\text { internationally }\end{array}$ & locally \\
\hline Close networks abroad with remit. & $\begin{array}{c}0.786 \\
(0.081)^{* * *}\end{array}$ & $\begin{array}{c}0.275 \\
(0.054)^{* * *}\end{array}$ & $\begin{array}{c}0.811 \\
(0.066)^{* * *}\end{array}$ & $\begin{array}{c}0.181 \\
(0.049)^{* * *}\end{array}$ \\
\hline Close networks abroad w/o remit. & $\begin{array}{c}0.520 \\
(0.056)^{* * *}\end{array}$ & $\begin{array}{c}0.124 \\
(0.028)^{* * *}\end{array}$ & $\begin{array}{c}0.581 \\
(0.061)^{* * *}\end{array}$ & $\begin{array}{c}0.121 \\
(0.030)^{* * *}\end{array}$ \\
\hline Close local networks with remit. & $\begin{array}{c}-0.163 \\
(0.092)^{*}\end{array}$ & $\begin{array}{l}-0.110 \\
(0.056)^{*}\end{array}$ & $\begin{array}{l}-0.157 \\
(0.118)\end{array}$ & $\begin{array}{l}-0.018 \\
(0.065)\end{array}$ \\
\hline Close local networks w/o remit. & $\begin{array}{c}-0.138 \\
(0.083)^{*}\end{array}$ & $\begin{array}{c}-0.134 \\
(0.041)^{* * *}\end{array}$ & $\begin{array}{c}-0.210 \\
(0.111)^{*}\end{array}$ & $\begin{array}{c}-0.142 \\
(0.052)^{* * *}\end{array}$ \\
\hline Broad networks abroad & $\begin{array}{c}0.570 \\
(0.093)^{* * *}\end{array}$ & & $\begin{array}{c}0.325 \\
(0.085)^{* * *}\end{array}$ & \\
\hline Broad local networks & & $\begin{array}{c}0.278 \\
(0.126)^{* *}\end{array}$ & & $\begin{array}{c}0.526 \\
(0.136)^{* * *}\end{array}$ \\
\hline Local amenities & $\begin{array}{c}-0.654 \\
(0.106)^{* * *}\end{array}$ & $\begin{array}{c}-0.476 \\
(0.061)^{* * *}\end{array}$ & $\begin{array}{c}-0.503 \\
(0.130)^{* * *}\end{array}$ & $\begin{array}{c}-0.390 \\
(0.057)^{* * *}\end{array}$ \\
\hline Local security & $\begin{array}{c}-0.475 \\
(0.116)^{* * *}\end{array}$ & $\begin{array}{c}-0.428 \\
(0.072)^{* * *}\end{array}$ & $\begin{array}{c}-0.313 \\
(0.142)^{* *}\end{array}$ & $\begin{array}{c}-0.419 \\
(0.062)^{* * *}\end{array}$ \\
\hline Contentment with the country & $\begin{array}{c}-0.324 \\
(0.105)^{* * *}\end{array}$ & $\begin{array}{l}-0.049 \\
(0.052)\end{array}$ & $\begin{array}{c}-0.465 \\
(0.130)^{* * *}\end{array}$ & $\begin{array}{c}-0.105 \\
(0.059)^{*}\end{array}$ \\
\hline Corruption & $\begin{array}{c}-0.282 \\
(0.124)^{* *}\end{array}$ & $\begin{array}{l}-0.009 \\
(0.065)\end{array}$ & $\begin{array}{l}-0.148 \\
(0.183)\end{array}$ & $\begin{array}{l}-0.122 \\
(0.088)\end{array}$ \\
\hline Work & $\begin{array}{c}-0.215 \\
(0.080)^{* * *}\end{array}$ & $\begin{array}{c}-0.223 \\
(0.044)^{* * *}\end{array}$ & $\begin{array}{c}-0.529 \\
(0.102)^{* * *}\end{array}$ & $\begin{array}{c}-0.250 \\
(0.040)^{* * *}\end{array}$ \\
\hline Wealth & $\begin{array}{l}-0.220 \\
(0.561)\end{array}$ & $\begin{array}{c}0.545 \\
(0.251)^{* *}\end{array}$ & $\begin{array}{c}0.175 \\
(0.767)\end{array}$ & $\begin{array}{c}0.100 \\
(0.477)\end{array}$ \\
\hline Standard of living & $\begin{array}{l}-0.403 \\
(0.569)\end{array}$ & $\begin{array}{l}-0.472 \\
(0.397)\end{array}$ & $\begin{array}{l}-0.442 \\
(0.692)\end{array}$ & $\begin{array}{c}0.241 \\
(0.454)\end{array}$ \\
\hline Standard of living sq. & $\begin{array}{l}-0.200 \\
(0.606)\end{array}$ & $\begin{array}{c}0.265 \\
(0.398)\end{array}$ & $\begin{array}{c}0.113 \\
(0.672)\end{array}$ & $\begin{array}{l}-0.309 \\
(0.456)\end{array}$ \\
\hline Married & $\begin{array}{c}-0.200 \\
(0.055)^{* * *} \\
(0.605)\end{array}$ & $\begin{array}{c}-0.144 \\
(0.026)^{* * *} \\
(0.268)^{*}\end{array}$ & $\begin{array}{c}-0.168 \\
(0.075)^{* *} \\
(0.683)\end{array}$ & $\begin{array}{c}-0.090 \\
(0.030)^{* * *} \\
(0.376)\end{array}$ \\
\hline Age & -0.014 & -0.014 & -0.018 & -0.015 \\
\hline Wealth sq. & $\begin{array}{c}0.675 \\
(0.002)^{* * *}\end{array}$ & $\begin{array}{c}-0.444 \\
(0.001)^{* * *}\end{array}$ & $\begin{array}{c}-0.144 \\
(0.003)^{* * *}\end{array}$ & $\begin{array}{c}-0.233 \\
(0.001)^{* * *}\end{array}$ \\
\hline Education (medium) & $\begin{array}{c}0.122 \\
(0.067)^{*}\end{array}$ & $\begin{array}{c}0.091 \\
(0.030)^{* * *}\end{array}$ & $\begin{array}{c}0.083 \\
(0.075)\end{array}$ & $\begin{array}{c}0.143 \\
(0.038)^{* * *}\end{array}$ \\
\hline Education (high) & $\begin{array}{c}0.190 \\
(0.127)\end{array}$ & $\begin{array}{c}0.212 \\
(0.052)^{* * *}\end{array}$ & $\begin{array}{c}0.248 \\
(0.098)^{* *}\end{array}$ & $\begin{array}{c}0.223 \\
(0.049)^{* * *}\end{array}$ \\
\hline Female & $\begin{array}{c}-0.164 \\
(0.053)^{* * *}\end{array}$ & $\begin{array}{c}-0.074 \\
(0.030)^{* *}\end{array}$ & $\begin{array}{c}-0.243 \\
(0.046)^{* * *}\end{array}$ & $\begin{array}{c}-0.097 \\
(0.031)^{* * *}\end{array}$ \\
\hline Large city & $\begin{array}{c}0.180 \\
(0.074)^{* *}\end{array}$ & $\begin{array}{c}0.064 \\
(0.029)^{* *}\end{array}$ & $\begin{array}{c}0.078 \\
(0.060)\end{array}$ & $\begin{array}{c}0.018 \\
(0.033)\end{array}$ \\
\hline Healthy & $\begin{array}{c}-0.143 \\
(0.054)^{* * *}\end{array}$ & $\begin{array}{c}-0.132 \\
(0.030)^{* * *}\end{array}$ & $\begin{array}{c}-0.155 \\
(0.067)^{* *}\end{array}$ & $\begin{array}{c}-0.190 \\
(0.035)^{* * *}\end{array}$ \\
\hline \# of children & $\begin{array}{c}0.009 \\
(0.012)\end{array}$ & $\begin{array}{c}0.002 \\
(0.007)\end{array}$ & $\begin{array}{c}0.025 \\
(0.016)\end{array}$ & $\begin{array}{c}-0.014 \\
(0.007)^{* *}\end{array}$ \\
\hline $\begin{array}{l}\text { Pseudo R2 } \\
N\end{array}$ & $\begin{array}{c}0.21 \\
24,856\end{array}$ & $\begin{array}{c}0.10 \\
33,179\end{array}$ & $\begin{array}{c}0.24 \\
20,121\end{array}$ & $\begin{array}{c}0.10 \\
26,187\end{array}$ \\
\hline
\end{tabular}

$* p<0.1 ; * * p<0.05 ; * * * p<0.01$

Table 12: Probit regressions by individual income, for specification in Table 8 .

Note: The table shows probit coefficients of sample-weighted regressions, st. errors are clustered at country-level, all specifications include year and country fixed effects and additional control variables at region and country-level which are omitted from the table. The dependent variable is a dummy for the intention to migrate locally or internationally (see text for details). The first two specifications include 'wealth' and 'standard of living' in a linear form, the last two specifications include these variables and their squared values. 'Local amenities' and 'local security' capture satisfaction at the city/local level, while 'contentment with the country' and 'corruption' reflect individual's satisfaction with the country-level institutions/amenities, 'work' reflects satisfaction with the job, 'close networks' reflect social networks (local and abroad) of the individual, while 'broad networks' are proxied by log of the share of other individuals at the current location that would like to move locally and abroad. For further details and description of individual controls see Section 4 . All of the indexes are principal components capturing information from the underlying variables - see Appendix B for further details. 


\begin{tabular}{|c|c|c|c|c|c|c|}
\hline & \multicolumn{2}{|c|}{ Low education } & \multicolumn{2}{|c|}{$\begin{array}{l}\text { Medium education } \\
\text { Intention to migrate }\end{array}$} & \multicolumn{2}{|c|}{ High education } \\
\hline & internationally & locally & internationally & locally & internationally & locally \\
\hline Close networks abroad with remit. & $\begin{array}{c}0.710 \\
(0.087)^{* * *}\end{array}$ & $\begin{array}{c}0.164 \\
(0.063)^{* * *}\end{array}$ & $\begin{array}{c}0.891 \\
(0.069)^{* * *}\end{array}$ & $\begin{array}{c}0.267 \\
(0.044)^{* * *}\end{array}$ & $\begin{array}{c}0.951 \\
(0.173)^{* * *}\end{array}$ & $\begin{array}{c}0.294 \\
(0.067)^{* * *}\end{array}$ \\
\hline Close networks abroad w/o remit. & $\begin{array}{c}0.525 \\
(0.057)^{* * *}\end{array}$ & $\begin{array}{c}0.054 \\
(0.037)\end{array}$ & $\begin{array}{c}0.594 \\
(0.066)^{* * *}\end{array}$ & $\begin{array}{c}0.171 \\
(0.028)^{* * *}\end{array}$ & $\begin{array}{c}0.543 \\
(0.112)^{* * *}\end{array}$ & $\begin{array}{c}0.138 \\
(0.043)^{* * *}\end{array}$ \\
\hline Close local networks with remit. & $\begin{array}{l}-0.226 \\
(0.129)^{*}\end{array}$ & $\begin{array}{l}-0.077 \\
(0.065)\end{array}$ & $\begin{array}{l}-0.171 \\
(0.104)\end{array}$ & $\begin{array}{l}-0.106 \\
(0.057)^{*}\end{array}$ & $\begin{array}{c}0.147 \\
(0.173)\end{array}$ & $\begin{array}{c}0.079 \\
(0.118)\end{array}$ \\
\hline Close local networks w/o remit. & $\begin{array}{l}-0.238 \\
(0.131)^{*}\end{array}$ & $\begin{array}{c}-0.131 \\
(0.040)^{* * *}\end{array}$ & $\begin{array}{c}-0.175 \\
(0.086)^{* *}\end{array}$ & $\begin{array}{c}-0.181 \\
(0.043)^{* * *}\end{array}$ & $\begin{array}{c}0.095 \\
(0.173)\end{array}$ & $\begin{array}{l}-0.031 \\
(0.111)\end{array}$ \\
\hline Broad networks abroad & $\begin{array}{c}0.549 \\
(0.177)^{* * *}\end{array}$ & & $\begin{array}{c}0.449 \\
(0.085)^{* * *}\end{array}$ & & $\begin{array}{c}0.338 \\
(0.241)\end{array}$ & \\
\hline Broad local networks & & $\begin{array}{c}0.419 \\
(0.170)^{* *}\end{array}$ & & $\begin{array}{c}0.461 \\
(0.163)^{* * *}\end{array}$ & & $\begin{array}{c}0.383 \\
(0.319)\end{array}$ \\
\hline Local amenities & $\begin{array}{c}-0.681 \\
(0.140)^{* * *}\end{array}$ & $\begin{array}{c}-0.389 \\
(0.067)^{* * *}\end{array}$ & $\begin{array}{c}-0.512 \\
(0.105)^{* * *}\end{array}$ & $\begin{array}{c}-0.542 \\
(0.055)^{* * *}\end{array}$ & $\begin{array}{c}-0.649 \\
(0.196)^{* * *}\end{array}$ & $\begin{array}{c}-0.375 \\
(0.095) * * *\end{array}$ \\
\hline Local security & $\begin{array}{c}-0.458 \\
(0.146)^{* * *}\end{array}$ & $\begin{array}{c}-0.425 \\
(0.083)^{* * *}\end{array}$ & $\begin{array}{c}-0.461 \\
(0.128)^{* * *}\end{array}$ & $\begin{array}{c}-0.423 \\
(0.076) * * *\end{array}$ & $\begin{array}{l}-0.222 \\
(0.309)\end{array}$ & $\begin{array}{c}-0.305 \\
(0.118) * * *\end{array}$ \\
\hline Contentment with the country & $\begin{array}{c}-0.365 \\
(0.098)^{* * *}\end{array}$ & $\begin{array}{l}-0.071 \\
(0.062)\end{array}$ & $\begin{array}{c}-0.339 \\
(0.115)^{* * *}\end{array}$ & $\begin{array}{l}-0.084 \\
(0.059)\end{array}$ & $\begin{array}{c}-0.765 \\
(0.310)^{* *}\end{array}$ & $\begin{array}{l}-0.113 \\
(0.086)\end{array}$ \\
\hline Corruption & $\begin{array}{c}-0.441 \\
(0.139)^{* * *}\end{array}$ & $\begin{array}{l}-0.028 \\
(0.094)\end{array}$ & $\begin{array}{l}-0.018 \\
(0.147)\end{array}$ & $\begin{array}{l}-0.048 \\
(0.064)\end{array}$ & $\begin{array}{l}-0.077 \\
(0.355)\end{array}$ & $\begin{array}{c}-0.310 \\
(0.132)^{* *}\end{array}$ \\
\hline Work & $\begin{array}{c}-0.419 \\
(0.098)^{* * *}\end{array}$ & $\begin{array}{c}-0.230 \\
(0.053)^{* * *}\end{array}$ & $\begin{array}{c}-0.270 \\
(0.092)^{* * *}\end{array}$ & $\begin{array}{c}-0.230 \\
(0.038)^{* * *}\end{array}$ & $\begin{array}{c}-0.381 \\
(0.145)^{* * *}\end{array}$ & $\begin{array}{l}-0.169 \\
(0.111)\end{array}$ \\
\hline Wealth & $\begin{array}{c}0.605 \\
(0.739)\end{array}$ & $\begin{array}{c}0.430 \\
(0.335)\end{array}$ & $\begin{array}{c}0.288 \\
(0.560)\end{array}$ & $\begin{array}{c}0.375 \\
(0.326)\end{array}$ & $\begin{array}{c}-2.666 \\
(1.353)^{* *}\end{array}$ & $\begin{array}{c}-1.806 \\
(0.855)^{* *}\end{array}$ \\
\hline Standard of living & $\begin{array}{l}-0.710 \\
(0.728)\end{array}$ & $\begin{array}{l}-0.842 \\
(0.539)\end{array}$ & $\begin{array}{c}0.007 \\
(0.632)\end{array}$ & $\begin{array}{c}0.424 \\
(0.384)\end{array}$ & $\begin{array}{c}0.227 \\
(1.490)\end{array}$ & $\begin{array}{l}-0.729 \\
(0.539)\end{array}$ \\
\hline Standard of living sq. & $\begin{array}{c}0.326 \\
(0.659)\end{array}$ & $\begin{array}{c}0.581 \\
(0.517)\end{array}$ & $\begin{array}{l}-0.724 \\
(0.719)\end{array}$ & $\begin{array}{l}-0.571 \\
(0.407)\end{array}$ & $\begin{array}{l}-0.073 \\
(1.604)\end{array}$ & $\begin{array}{c}0.899 \\
(0.572)\end{array}$ \\
\hline Married & $\begin{array}{c}-0.118 \\
(0.069)^{*} \\
(0.771)\end{array}$ & $\begin{array}{c}-0.108 \\
(0.034)^{* * *} \\
(0.373)\end{array}$ & $\begin{array}{c}-0.215 \\
(0.054)^{* * *} \\
(0.505)\end{array}$ & $\begin{array}{c}-0.093 \\
(0.029)^{* * *} \\
(0.257)\end{array}$ & $\begin{array}{c}-0.450 \\
(0.111)^{* * *} \\
(1.041)^{*}\end{array}$ & $\begin{array}{c}-0.210 \\
(0.052)^{* * *} \\
(0.661)\end{array}$ \\
\hline Age & -0.015 & -0.013 & -0.015 & -0.016 & -0.018 & -0.018 \\
\hline Wealth sq. & $\begin{array}{c}-0.389 \\
(0.003)^{* * *}\end{array}$ & $\begin{array}{c}-0.348 \\
(0.001)^{* * *}\end{array}$ & $\begin{array}{c}-0.184 \\
(0.003)^{* * *}\end{array}$ & $\begin{array}{c}-0.352 \\
(0.001)^{* * *}\end{array}$ & $\begin{array}{c}1.831 \\
(0.003)^{* * *}\end{array}$ & $\begin{array}{c}0.936 \\
(0.003)^{* * *}\end{array}$ \\
\hline Female & $\begin{array}{c}-0.241 \\
(0.062)^{* * *}\end{array}$ & $\begin{array}{c}-0.116 \\
(0.044)^{* * *}\end{array}$ & $\begin{array}{c}-0.174 \\
(0.059)^{* * *}\end{array}$ & $\begin{array}{c}-0.051 \\
(0.027)^{*}\end{array}$ & $\begin{array}{l}-0.130 \\
(0.094)\end{array}$ & $\begin{array}{c}-0.086 \\
(0.046)^{*}\end{array}$ \\
\hline Large city & $\begin{array}{c}0.252 \\
(0.109)^{* *}\end{array}$ & $\begin{array}{c}0.115 \\
(0.044)^{* * *}\end{array}$ & $\begin{array}{c}0.049 \\
(0.054)\end{array}$ & $\begin{array}{c}0.006 \\
(0.034)\end{array}$ & $\begin{array}{c}0.083 \\
(0.095)\end{array}$ & $\begin{array}{l}-0.002 \\
(0.046)\end{array}$ \\
\hline Healthy & $\begin{array}{c}-0.143 \\
(0.067)^{* *}\end{array}$ & $\begin{array}{c}-0.182 \\
(0.034)^{* * *}\end{array}$ & $\begin{array}{c}-0.127 \\
(0.068)^{*}\end{array}$ & $\begin{array}{c}-0.130 \\
(0.032)^{* * *}\end{array}$ & $\begin{array}{c}-0.374 \\
(0.121)^{* * *}\end{array}$ & $\begin{array}{c}-0.129 \\
(0.063)^{* *}\end{array}$ \\
\hline \# of children & $\begin{array}{c}0.027 \\
(0.013)^{* *}\end{array}$ & $\begin{array}{c}0.007 \\
(0.007)\end{array}$ & $\begin{array}{l}-0.000 \\
(0.014)\end{array}$ & $\begin{array}{c}-0.014 \\
(0.008)^{*}\end{array}$ & $\begin{array}{c}0.025 \\
(0.034)\end{array}$ & $\begin{array}{l}-0.023 \\
(0.019)\end{array}$ \\
\hline Pseudo R2 & 0.23 & 0.08 & 0.23 & 0.12 & 0.24 & 0.11 \\
\hline$N$ & 16,282 & 21,555 & 21,632 & 29,341 & 5,922 & 8,590 \\
\hline
\end{tabular}

$* p<0.1 ; * * p<0.05 ; * * * p<0.01$

Table 13: Probit regressions by individual education, for specification in Table 9 .

Note: The table shows probit coefficients of sample-weighted regressions, st. errors are clustered at country-level, all specifications include year and country fixed effects and additional control variables at region and country-level which are omitted from the table. The dependent variable is a dummy for the intention to migrate locally or internationally (see text for details). The first two specifications include 'wealth' and 'standard of living' in a linear form, the last two specifications include these variables and their squared values. 'Local amenities' and 'local security' capture satisfaction at the city/local level, while 'contentment with the country' and 'corruption' reflect individual's satisfaction with the country-level institutions/amenities, 'work' reflects satisfaction with the job, 'close networks' reflect social networks (local and abroad) of the individual, while 'broad networks' are proxied by log of the share of other individuals at the current location that would like to move locally and abroad. For further details and description of individual controls see Section 1 . All of the indexes are principal components capturing information from the underlying variables - see Appendix B for further details. 


\begin{tabular}{|c|c|c|c|c|}
\hline & \multicolumn{2}{|c|}{ Low income (1-3 quintiles) } & \multicolumn{2}{|c|}{ High income (4-5 quintiles) } \\
\hline & & Intention & & \\
\hline & internationally & locally & internationally & locally \\
\hline Close networks abroad with remit. & $\begin{array}{c}0.113 \\
(0.035)^{* * *}\end{array}$ & $\begin{array}{c}0.133 \\
(0.034)^{* * *}\end{array}$ & $\begin{array}{c}0.158 \\
(0.025)^{* * *}\end{array}$ & $\begin{array}{c}0.067 \\
(0.028)^{* *}\end{array}$ \\
\hline Close networks abroad w/o remit. & $\begin{array}{c}0.065 \\
(0.018)^{* * *}\end{array}$ & $\begin{array}{c}0.024 \\
(0.026)\end{array}$ & $\begin{array}{c}0.089 \\
(0.014)^{* * *}\end{array}$ & $\begin{array}{c}0.038 \\
(0.017)^{* *}\end{array}$ \\
\hline Close local networks with remit. & $\begin{array}{c}-0.040 \\
(0.023)^{*}\end{array}$ & $\begin{array}{l}-0.038 \\
(0.039)\end{array}$ & $\begin{array}{l}-0.025 \\
(0.025)\end{array}$ & $\begin{array}{l}-0.002 \\
(0.032)\end{array}$ \\
\hline Close local networks w/o remit. & $\begin{array}{l}-0.020 \\
(0.024)\end{array}$ & $\begin{array}{l}-0.018 \\
(0.038)\end{array}$ & $\begin{array}{c}-0.041 \\
(0.025)^{*}\end{array}$ & $\begin{array}{l}-0.018 \\
(0.035)\end{array}$ \\
\hline Broad networks abroad & $\begin{array}{c}0.053 \\
(0.015)^{* * *}\end{array}$ & & $\begin{array}{c}-0.061 \\
(0.028)^{* *}\end{array}$ & \\
\hline Broad local networks & & $\begin{array}{c}-0.068 \\
(0.022)^{* * *}\end{array}$ & & $\begin{array}{c}-13.471 \\
(2.155)^{* * *}\end{array}$ \\
\hline Local amenities & $\begin{array}{c}-0.122 \\
(0.029)^{* * *}\end{array}$ & $\begin{array}{c}-0.094 \\
(0.036)^{* * *}\end{array}$ & $\begin{array}{l}-0.019 \\
(0.026)\end{array}$ & $\begin{array}{c}-0.089 \\
(0.031)^{* * *}\end{array}$ \\
\hline Local security & $\begin{array}{l}-0.030 \\
(0.031)\end{array}$ & $\begin{array}{l}-0.023 \\
(0.038)\end{array}$ & $\begin{array}{l}-0.021 \\
(0.028)\end{array}$ & $\begin{array}{c}-0.165 \\
(0.044)^{* * *}\end{array}$ \\
\hline Contentment with the country & $\begin{array}{c}-0.048 \\
(0.026)^{*}\end{array}$ & $\begin{array}{l}-0.049 \\
(0.043)\end{array}$ & $\begin{array}{c}-0.033 \\
(0.019)^{*}\end{array}$ & $\begin{array}{c}-0.073 \\
(0.035)^{* *}\end{array}$ \\
\hline Corruption & $\begin{array}{c}-0.070 \\
(0.032)^{* *}\end{array}$ & $\begin{array}{l}-0.057 \\
(0.046)\end{array}$ & $\begin{array}{l}-0.007 \\
(0.030)\end{array}$ & $\begin{array}{l}-0.022 \\
(0.050)\end{array}$ \\
\hline Work & $\begin{array}{c}-0.057 \\
(0.019)^{* * *}\end{array}$ & $\begin{array}{c}-0.093 \\
(0.031)^{* * *}\end{array}$ & $\begin{array}{c}-0.028 \\
(0.016)^{*}\end{array}$ & $\begin{array}{l}-0.001 \\
(0.029)\end{array}$ \\
\hline Wealth & $\begin{array}{c}0.036 \\
(0.043)\end{array}$ & $\begin{array}{l}-0.049 \\
(0.058)\end{array}$ & $\begin{array}{c}0.055 \\
(0.039)\end{array}$ & $\begin{array}{c}-0.112 \\
(0.061)^{*}\end{array}$ \\
\hline Standard of living & $\begin{array}{c}0.031 \\
(0.046)\end{array}$ & $\begin{array}{l}-0.065 \\
(0.084)\end{array}$ & $\begin{array}{c}-0.080 \\
(0.043)^{*}\end{array}$ & $\begin{array}{l}-0.036 \\
(0.060)\end{array}$ \\
\hline Married & $\begin{array}{c}-0.026 \\
(0.012)^{* *}\end{array}$ & $\begin{array}{c}-0.072 \\
(0.020)^{* * *}\end{array}$ & $\begin{array}{l}-0.019 \\
(0.013)\end{array}$ & $\begin{array}{l}-0.016 \\
(0.019)\end{array}$ \\
\hline Age & $\begin{array}{c}-0.001 \\
(0.001)^{* *}\end{array}$ & $\begin{array}{c}-0.003 \\
(0.001)^{* * *}\end{array}$ & $\begin{array}{c}-0.001 \\
(0.000)\end{array}$ & $\begin{array}{c}-0.004 \\
(0.001)^{* * *}\end{array}$ \\
\hline Education (medium) & $\begin{array}{c}0.010 \\
(0.015)\end{array}$ & $\begin{array}{c}0.068 \\
(0.022)^{* * *}\end{array}$ & $\begin{array}{c}0.005 \\
(0.016)\end{array}$ & $\begin{array}{c}0.051 \\
(0.023)^{* *}\end{array}$ \\
\hline Education (high) & $\begin{array}{l}-0.006 \\
(0.031)\end{array}$ & $\begin{array}{c}0.072 \\
(0.032)^{* *}\end{array}$ & $\begin{array}{l}-0.015 \\
(0.017)\end{array}$ & $\begin{array}{c}0.069 \\
(0.030)^{* *}\end{array}$ \\
\hline Female & $\begin{array}{c}-0.027 \\
(0.010)^{* * *}\end{array}$ & $\begin{array}{l}-0.000 \\
(0.018)\end{array}$ & $\begin{array}{c}0.002 \\
(0.010)\end{array}$ & $\begin{array}{l}-0.003 \\
(0.015)\end{array}$ \\
\hline Large city & $\begin{array}{c}0.048 \\
(0.024)^{* *}\end{array}$ & $\begin{array}{c}0.041 \\
(0.027)\end{array}$ & $\begin{array}{l}-0.005 \\
(0.012)\end{array}$ & $\begin{array}{l}-0.014 \\
(0.017)\end{array}$ \\
\hline Healthy & $\begin{array}{c}-0.042 \\
(0.021)^{* *}\end{array}$ & $\begin{array}{c}-0.035 \\
(0.017)^{* *}\end{array}$ & $\begin{array}{c}0.023 \\
(0.011)^{* *}\end{array}$ & $\begin{array}{l}-0.040 \\
(0.026)\end{array}$ \\
\hline \# of children & $\begin{array}{l}-0.002 \\
(0.003)\end{array}$ & $\begin{array}{l}-0.005 \\
(0.006)\end{array}$ & $\begin{array}{c}-0.001 \\
(0.003)\end{array}$ & $\begin{array}{l}-0.002 \\
(0.005)\end{array}$ \\
\hline $\begin{array}{l}\text { Pseudo R2 } \\
N\end{array}$ & $\begin{array}{c}0.30 \\
1,833\end{array}$ & $\begin{array}{c}0.13 \\
3,326\end{array}$ & $\begin{array}{c}0.24 \\
2,273\end{array}$ & $\begin{array}{c}0.11 \\
3,723\end{array}$ \\
\hline Close networks (abroad) test & n.s. & $* * *$ & $* *$ & n.s. \\
\hline Close networks (local) test & n.s. & n.s. & n.s. & n.s. \\
\hline
\end{tabular}

Table 14: Sample restricted to those that send remittances locally, abroad or both - split by income

Note: The table shows marginal effects of sample-weighted probit regressions, st. errors are clustered at country-level. Regressions include additional control variables at region and country-level which are omitted from the table. The dependent variable is a dummy for the intention to migrate locally or internationally (see text for details). Low education is defined as up to eight years of basic schooling, medium education - 9 to 15 years of education (completed secondary education and up to three years of tertiary education), high education - above 15 years of education (completed four years of education beyond high school and/or received a four-year college degree. All specifications include 'wealth' and 'standard of living' and their squared values. 'Local amenities' and 'local security' capture satisfaction at the city/local level, while 'contentment with the country' and 'corruption' reflect individual's satisfaction with the country-level institutions/amenities, 'work' reflects satisfaction with the job, 'close networks' reflect social networks (local and abroad) of the individual, while 'broad networks' are proxied by log of the share of individuals at the current location that would like to move locally and abroad. For further details and description of individual controls see Section 4 . All of the indexes are principal components capturing information from the underlying variables - see Appendix B for further details. 


\begin{tabular}{|c|c|c|c|c|c|c|}
\hline & \multicolumn{2}{|c|}{ Low education } & \multicolumn{2}{|c|}{$\begin{array}{l}\text { Medium education } \\
\text { Intention to migrate }\end{array}$} & \multicolumn{2}{|c|}{ High education } \\
\hline & internationally & locally & internationally & locally & internationally & locally \\
\hline Close networks abroad with remit. & $\begin{array}{c}0.119 \\
(0.040)^{* * *}\end{array}$ & $\begin{array}{c}0.083 \\
(0.045)^{*}\end{array}$ & $\begin{array}{c}0.144 \\
(0.026) * * *\end{array}$ & $\begin{array}{c}0.067 \\
(0.034)^{* *}\end{array}$ & $\begin{array}{c}0.284 \\
(0.084)^{* * *}\end{array}$ & $\begin{array}{c}0.171 \\
(0.058) * * *\end{array}$ \\
\hline Close networks abroad w/o remit. & $\begin{array}{c}0.084 \\
(0.020)^{* * *}\end{array}$ & $\begin{array}{c}0.021 \\
(0.024)\end{array}$ & $\begin{array}{c}0.094 \\
(0.016) * * *\end{array}$ & $\begin{array}{c}0.046 \\
(0.020)^{* *}\end{array}$ & $\begin{array}{c}0.069 \\
(0.040)^{*}\end{array}$ & $\begin{array}{c}0.050 \\
(0.034)\end{array}$ \\
\hline Close local networks with remit. & $\begin{array}{l}-0.034 \\
(0.036)\end{array}$ & $\begin{array}{l}-0.008 \\
(0.033)\end{array}$ & $\begin{array}{l}-0.024 \\
(0.022)\end{array}$ & $\begin{array}{l}-0.042 \\
(0.044)\end{array}$ & $\begin{array}{l}-0.017 \\
(0.068)\end{array}$ & $\begin{array}{c}0.087 \\
(0.075)\end{array}$ \\
\hline Close local networks w/o remit. & $\begin{array}{l}-0.048 \\
(0.039)\end{array}$ & $\begin{array}{l}-0.013 \\
(0.034)\end{array}$ & $\begin{array}{l}-0.019 \\
(0.018)\end{array}$ & $\begin{array}{l}-0.032 \\
(0.039)\end{array}$ & $\begin{array}{l}-0.002 \\
(0.072)\end{array}$ & $\begin{array}{c}0.100 \\
(0.069)\end{array}$ \\
\hline Broad networks abroad & $\begin{array}{l}-0.030 \\
(0.021)\end{array}$ & & $\begin{array}{c}-0.118 \\
(0.018)^{* * *}\end{array}$ & & $\begin{array}{c}0.003 \\
(0.061)\end{array}$ & \\
\hline Broad local networks & & $\begin{array}{c}-29.070 \\
(3.219)^{* * *}\end{array}$ & & $\begin{array}{c}-0.083 \\
(0.040)^{* *}\end{array}$ & & $\begin{array}{c}-10.156 \\
(4.715)^{* *}\end{array}$ \\
\hline Local amenities & $\begin{array}{c}-0.083 \\
(0.029)^{* * *}\end{array}$ & $\begin{array}{c}-0.068 \\
(0.039)^{*}\end{array}$ & $\begin{array}{c}-0.081 \\
(0.033)^{* *}\end{array}$ & $\begin{array}{c}-0.137 \\
(0.034)^{* * *}\end{array}$ & $\begin{array}{c}0.013 \\
(0.048)\end{array}$ & $\begin{array}{l}-0.092 \\
(0.082)\end{array}$ \\
\hline Local security & $\begin{array}{c}0.004 \\
(0.042)\end{array}$ & $\begin{array}{l}-0.026 \\
(0.052)\end{array}$ & $\begin{array}{c}-0.096 \\
(0.028) * * *\end{array}$ & $\begin{array}{c}-0.151 \\
(0.040)^{* * *}\end{array}$ & $\begin{array}{c}0.098 \\
(0.052)^{*}\end{array}$ & $\begin{array}{c}-0.180 \\
(0.071)^{* *}\end{array}$ \\
\hline Contentment with the country & $\begin{array}{c}-0.053 \\
(0.026)^{* *}\end{array}$ & $\begin{array}{c}-0.097 \\
(0.046)^{* *}\end{array}$ & $\begin{array}{l}-0.021 \\
(0.030)\end{array}$ & $\begin{array}{l}-0.034 \\
(0.055)\end{array}$ & $\begin{array}{c}-0.226 \\
(0.071)^{* * *}\end{array}$ & $\begin{array}{l}-0.013 \\
(0.065)\end{array}$ \\
\hline Corruption & $\begin{array}{l}-0.055 \\
(0.052)\end{array}$ & $\begin{array}{l}-0.091 \\
(0.057)\end{array}$ & $\begin{array}{c}0.013 \\
(0.035)\end{array}$ & $\begin{array}{c}0.045 \\
(0.047)\end{array}$ & $\begin{array}{c}-0.184 \\
(0.096)^{*}\end{array}$ & $\begin{array}{l}-0.115 \\
(0.095)\end{array}$ \\
\hline Work & $\begin{array}{l}-0.049 \\
(0.036)\end{array}$ & $\begin{array}{l}-0.017 \\
(0.038)\end{array}$ & $\begin{array}{c}-0.046 \\
(0.018)^{* * *}\end{array}$ & $\begin{array}{c}-0.081 \\
(0.025) * * *\end{array}$ & $\begin{array}{l}-0.042 \\
(0.067)\end{array}$ & $\begin{array}{c}0.030 \\
(0.057)\end{array}$ \\
\hline Wealth & $\begin{array}{c}0.018 \\
(0.040)\end{array}$ & $\begin{array}{l}-0.097 \\
(0.062)\end{array}$ & $\begin{array}{c}0.054 \\
(0.047)\end{array}$ & $\begin{array}{l}-0.054 \\
(0.051)\end{array}$ & $\begin{array}{l}-0.023 \\
(0.161)\end{array}$ & $\begin{array}{l}-0.142 \\
(0.103)\end{array}$ \\
\hline Standard of living & $\begin{array}{l}-0.030 \\
(0.067)\end{array}$ & $\begin{array}{l}-0.043 \\
(0.102)\end{array}$ & $\begin{array}{l}-0.045 \\
(0.047)\end{array}$ & $\begin{array}{l}-0.093 \\
(0.069)\end{array}$ & $\begin{array}{c}0.412 \\
(0.110)^{* * *}\end{array}$ & $\begin{array}{c}0.167 \\
(0.155)\end{array}$ \\
\hline Married & $\begin{array}{l}-0.027 \\
(0.023)\end{array}$ & $\begin{array}{l}-0.008 \\
(0.021)\end{array}$ & $\begin{array}{c}-0.024 \\
(0.011)^{* *}\end{array}$ & $\begin{array}{c}-0.041 \\
(0.019)^{* *}\end{array}$ & $\begin{array}{c}-0.071 \\
(0.032)^{* *}\end{array}$ & $\begin{array}{c}-0.155 \\
(0.043)^{* * *}\end{array}$ \\
\hline Age & $\begin{array}{l}-0.000 \\
(0.001)\end{array}$ & $\begin{array}{c}-0.003 \\
(0.001)^{* * *}\end{array}$ & $\begin{array}{l}-0.001 \\
(0.001)\end{array}$ & $\begin{array}{c}-0.005 \\
(0.001)^{* * *}\end{array}$ & $\begin{array}{c}-0.005 \\
(0.002)^{* * *}\end{array}$ & $\begin{array}{c}-0.004 \\
(0.001)^{* * *}\end{array}$ \\
\hline Female & $\begin{array}{c}-0.045 \\
(0.011)^{* * *}\end{array}$ & $\begin{array}{c}0.012 \\
(0.014)\end{array}$ & $\begin{array}{l}-0.012 \\
(0.013)\end{array}$ & $\begin{array}{c}-0.036 \\
(0.015)^{* *}\end{array}$ & $\begin{array}{c}0.048 \\
(0.033)\end{array}$ & $\begin{array}{c}0.071 \\
(0.032)^{* *}\end{array}$ \\
\hline Large city & $\begin{array}{c}0.018 \\
(0.026)\end{array}$ & $\begin{array}{c}0.043 \\
(0.029)\end{array}$ & $\begin{array}{c}0.025 \\
(0.015)\end{array}$ & $\begin{array}{l}-0.010 \\
(0.018)\end{array}$ & $\begin{array}{c}-0.069 \\
(0.041)^{*}\end{array}$ & $\begin{array}{c}0.025 \\
(0.036)\end{array}$ \\
\hline Healthy & $\begin{array}{l}-0.017 \\
(0.031)\end{array}$ & $\begin{array}{c}-0.050 \\
(0.026)^{*}\end{array}$ & $\begin{array}{l}-0.006 \\
(0.016)\end{array}$ & $\begin{array}{l}-0.025 \\
(0.023)\end{array}$ & $\begin{array}{l}-0.033 \\
(0.050)\end{array}$ & $\begin{array}{l}-0.065 \\
(0.057)\end{array}$ \\
\hline \# of children & $\begin{array}{c}0.005 \\
(0.005)\end{array}$ & $\begin{array}{l}-0.002 \\
(0.005)\end{array}$ & $\begin{array}{c}-0.006 \\
(0.003)^{*}\end{array}$ & $\begin{array}{l}-0.004 \\
(0.006)\end{array}$ & $\begin{array}{l}-0.008 \\
(0.013)\end{array}$ & $\begin{array}{c}0.000 \\
(0.011)\end{array}$ \\
\hline $\begin{array}{l}\text { Pseudo R2 } \\
N\end{array}$ & $\begin{array}{l}0.30 \\
996\end{array}$ & $\begin{array}{c}0.12 \\
2,333\end{array}$ & $\begin{array}{c}0.22 \\
2,284\end{array}$ & $\begin{array}{c}0.12 \\
3,798\end{array}$ & $\begin{array}{l}0.41 \\
358\end{array}$ & $\begin{array}{l}0.17 \\
941\end{array}$ \\
\hline $\begin{array}{l}\text { Close networks (abroad) test } \\
\text { Close networks (local) test }\end{array}$ & $\begin{array}{l}\text { n.s. } \\
\text { n.s. }\end{array}$ & $\begin{array}{l}\text { n.s. } \\
\text { n.s. }\end{array}$ & $\begin{array}{l}\text { n.s. } \\
\text { n.s. }\end{array}$ & $\begin{array}{l}\text { n.s. } \\
\text { n.s. }\end{array}$ & $\begin{array}{l}* * * \\
\text { n.s. }\end{array}$ & $\begin{array}{l}* * * \\
\text { n.s. }\end{array}$ \\
\hline
\end{tabular}

${ }^{*} p<0.1 ; * * p<0.05 ; * * * p<0.01$

Table 15: Sample restricted to those that send remittances locally, abroad or both - split by education

Note: The table shows marginal effects of sample-weighted probit regressions, st. errors are clustered at country-level. Regressions include additional control variables at region and country-level which are omitted from the table. The dependent variable is a dummy for the intention to migrate locally or internationally (see text for details). Low education is defined as up to eight years of basic schooling, medium education - 9 to 15 years of education (completed secondary education and up to three years of tertiary education), high education - above 15 years of education (completed four years of education beyond high school and/or received a four-year college degree. All specifications include 'wealth' and 'standard of living' and their squared values. 'Local amenities' and 'local security' capture satisfaction at the city/local level, while 'contentment with the country' and 'corruption' reflect individual's satisfaction with the country-level institutions/amenities, 'work' reflects satisfaction with the job, 'close networks' reflect social networks (local and abroad) of the individual, while 'broad networks' are proxied by log of the share of individuals at the current location that would like to move locally and abroad. For further details and description of individual controls see Section 4 . All of the indexes are principal components capturing information from the underlying variables - see Appendix B for further details. 


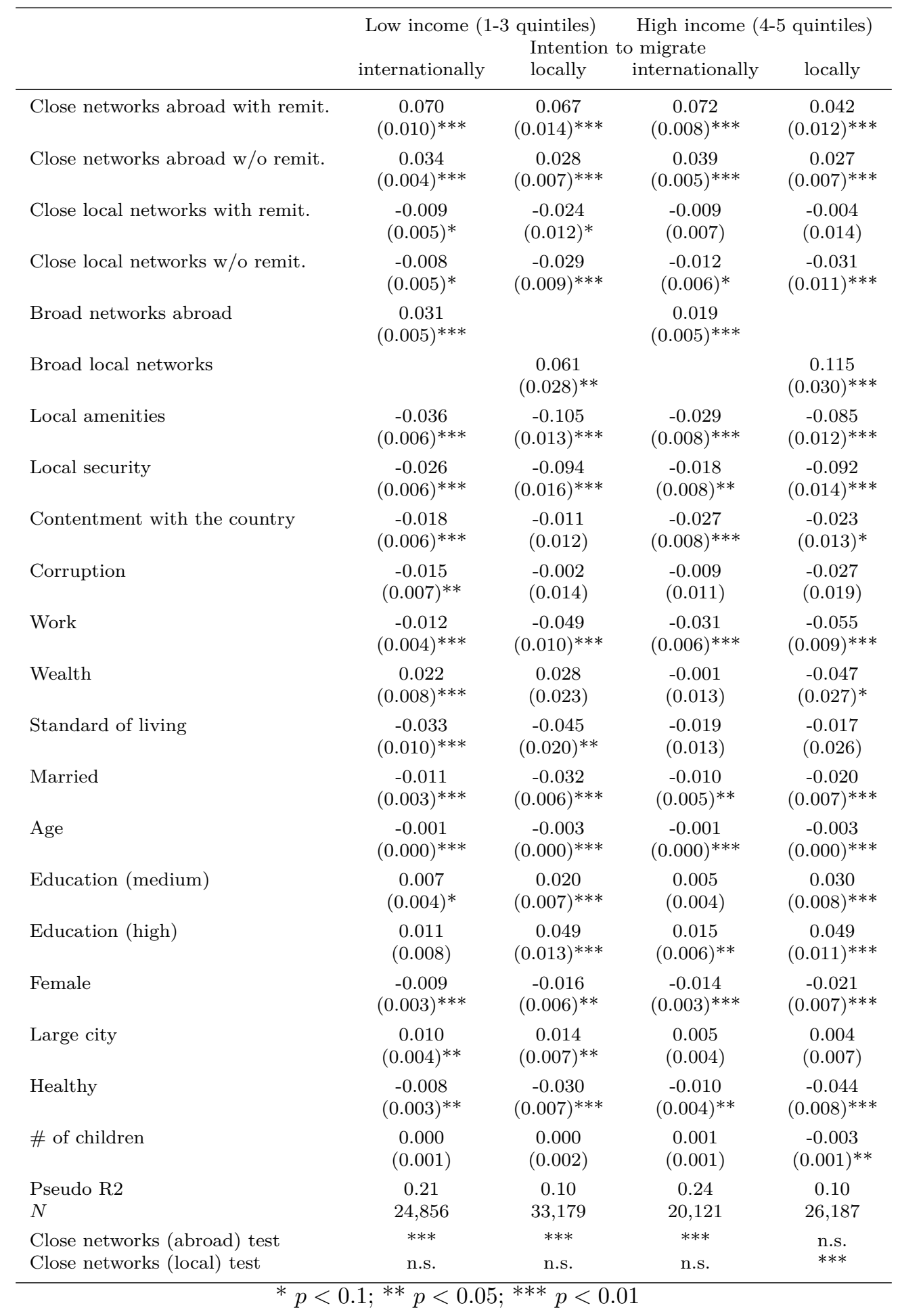

Table 16: Intention to migrate and income levels, full results corresponding to Table 8 .

Note: The table shows marginal effects of sample-weighted probit regressions, st. errors are clustered at country-level, all specifications include year and country fixed effects and additional control variables at region and country-level which are omitted from the table. The dependent variable is a dummy for the intention to migrate locally or internationally (see text for details). All specifications include 'wealth' and 'standard of living' and their squared values. 'Local amenities' and 'local security' capture satisfaction at the city/local level, while 'contentment with the country' and 'corruption' reflect individual's satisfaction with the country-level institutions/amenities, 'work' reflects satisfaction with the job, 'close networks' reflect social networks (local and abroad) of the individual, while 'broad networks' are proxied by log of the share of other individuals at the current location that would like to move locally and abroad. For further details and description of individual controls see Section 4 . All of the indexes are principal components capturing information from the underlying variables - see Appendix B for further details. 


\begin{tabular}{|c|c|c|c|c|c|c|}
\hline & \multicolumn{2}{|c|}{ Low education } & \multicolumn{2}{|c|}{$\begin{array}{l}\text { Medium education } \\
\text { Intention to migrate }\end{array}$} & \multicolumn{2}{|c|}{ High education } \\
\hline & internationally & locally & internationally & locally & internationally & locally \\
\hline Close networks abroad with remit. & $\begin{array}{c}0.059 \\
(0.010)^{* * *}\end{array}$ & $\begin{array}{c}0.038 \\
(0.015)^{* *}\end{array}$ & $\begin{array}{c}0.086 \\
(0.009)^{* * *}\end{array}$ & $\begin{array}{c}0.065 \\
(0.012)^{* * *}\end{array}$ & $\begin{array}{c}0.099 \\
(0.026)^{* * *}\end{array}$ & $\begin{array}{c}0.072 \\
(0.018) * * *\end{array}$ \\
\hline Close networks abroad w/o remit. & $\begin{array}{c}0.035 \\
(0.004)^{* * *}\end{array}$ & $\begin{array}{c}0.012 \\
(0.008)\end{array}$ & $\begin{array}{c}0.041 \\
(0.005)^{* * *}\end{array}$ & $\begin{array}{c}0.039 \\
(0.006)^{* * *}\end{array}$ & $\begin{array}{c}0.036 \\
(0.007)^{* * *}\end{array}$ & $\begin{array}{c}0.031 \\
(0.010)^{* * *}\end{array}$ \\
\hline Close local networks with remit. & $\begin{array}{c}-0.012 \\
(0.007)^{*}\end{array}$ & $\begin{array}{l}-0.017 \\
(0.014)\end{array}$ & $\begin{array}{l}-0.010 \\
(0.006)\end{array}$ & $\begin{array}{c}-0.024 \\
(0.013)^{*}\end{array}$ & $\begin{array}{c}0.009 \\
(0.011)\end{array}$ & $\begin{array}{c}0.018 \\
(0.026)\end{array}$ \\
\hline Close local networks w/o remit. & $\begin{array}{c}-0.013 \\
(0.007)^{*}\end{array}$ & $\begin{array}{c}-0.028 \\
(0.009)^{* * *}\end{array}$ & $\begin{array}{c}-0.010 \\
(0.005)^{* *}\end{array}$ & $\begin{array}{c}-0.040 \\
(0.010)^{* * *}\end{array}$ & $\begin{array}{c}0.006 \\
(0.011)\end{array}$ & $\begin{array}{l}-0.007 \\
(0.025)\end{array}$ \\
\hline Broad networks abroad & $\begin{array}{c}0.030 \\
(0.010)^{* * *}\end{array}$ & & $\begin{array}{c}0.027 \\
(0.005)^{* * *}\end{array}$ & & $\begin{array}{c}0.021 \\
(0.015)\end{array}$ & \\
\hline Broad local networks & & $\begin{array}{c}0.091 \\
(0.037)^{* *}\end{array}$ & & $\begin{array}{c}0.102 \\
(0.036)^{* * *}\end{array}$ & & $\begin{array}{c}0.085 \\
(0.071)\end{array}$ \\
\hline Local amenities & $\begin{array}{c}-0.037 \\
(0.008)^{* * *}\end{array}$ & $\begin{array}{c}-0.085 \\
(0.014)^{* * *}\end{array}$ & $\begin{array}{c}-0.030 \\
(0.006)^{* * *}\end{array}$ & $\begin{array}{c}-0.120 \\
(0.012)^{* * *}\end{array}$ & $\begin{array}{c}-0.041 \\
(0.012)^{* * *}\end{array}$ & $\begin{array}{c}-0.083 \\
(0.021)^{* * *}\end{array}$ \\
\hline Local security & $\begin{array}{c}-0.025 \\
(0.008)^{* * *}\end{array}$ & $\begin{array}{c}-0.092 \\
(0.018)^{* * *}\end{array}$ & $\begin{array}{c}-0.027 \\
(0.008)^{* * *}\end{array}$ & $\begin{array}{c}-0.094 \\
(0.017)^{* * *}\end{array}$ & $\begin{array}{l}-0.014 \\
(0.019)\end{array}$ & $\begin{array}{c}-0.068 \\
(0.026)^{* * *}\end{array}$ \\
\hline Contentment with the country & $\begin{array}{c}-0.020 \\
(0.005)^{* * *}\end{array}$ & $\begin{array}{l}-0.015 \\
(0.014)\end{array}$ & $\begin{array}{c}-0.020 \\
(0.007)^{* * *}\end{array}$ & $\begin{array}{l}-0.019 \\
(0.013)\end{array}$ & $\begin{array}{c}-0.048 \\
(0.019)^{* *}\end{array}$ & $\begin{array}{l}-0.025 \\
(0.019)\end{array}$ \\
\hline Corruption & $\begin{array}{c}-0.024 \\
(0.008)^{* * *}\end{array}$ & $\begin{array}{l}-0.006 \\
(0.020)\end{array}$ & $\begin{array}{l}-0.001 \\
(0.009)\end{array}$ & $\begin{array}{l}-0.011 \\
(0.014)\end{array}$ & $\begin{array}{l}-0.005 \\
(0.022)\end{array}$ & $\begin{array}{c}-0.069 \\
(0.029)^{* *}\end{array}$ \\
\hline Work & $\begin{array}{c}-0.023 \\
(0.005)^{* * *}\end{array}$ & $\begin{array}{c}-0.050 \\
(0.011)^{* * *}\end{array}$ & $\begin{array}{c}-0.016 \\
(0.005)^{* * *}\end{array}$ & $\begin{array}{c}-0.051 \\
(0.008)^{* * *}\end{array}$ & $\begin{array}{c}-0.024 \\
(0.009)^{* * *}\end{array}$ & $\begin{array}{l}-0.037 \\
(0.025)\end{array}$ \\
\hline Wealth & $\begin{array}{c}0.015 \\
(0.009)\end{array}$ & $\begin{array}{c}0.027 \\
(0.021)\end{array}$ & $\begin{array}{c}0.004 \\
(0.010)\end{array}$ & $\begin{array}{l}-0.015 \\
(0.017)\end{array}$ & $\begin{array}{c}0.004 \\
(0.029)\end{array}$ & $\begin{array}{l}-0.086 \\
(0.061)\end{array}$ \\
\hline Standard of living & $\begin{array}{l}-0.020 \\
(0.013)\end{array}$ & $\begin{array}{c}-0.046 \\
(0.027)^{*}\end{array}$ & $\begin{array}{c}-0.039 \\
(0.011)^{* * *}\end{array}$ & $\begin{array}{l}-0.030 \\
(0.027)\end{array}$ & $\begin{array}{c}0.010 \\
(0.021)\end{array}$ & $\begin{array}{c}0.030 \\
(0.040)\end{array}$ \\
\hline Married & $\begin{array}{c}-0.007 \\
(0.004)^{*}\end{array}$ & $\begin{array}{c}-0.024 \\
(0.008)^{* * *}\end{array}$ & $\begin{array}{c}-0.013 \\
(0.003)^{* * *}\end{array}$ & $\begin{array}{c}-0.021 \\
(0.007)^{* * *}\end{array}$ & $\begin{array}{c}-0.029 \\
(0.007)^{* * *}\end{array}$ & $\begin{array}{c}-0.048 \\
(0.012)^{* * *}\end{array}$ \\
\hline Age & $\begin{array}{c}-0.001 \\
(0.000)^{* * *}\end{array}$ & $\begin{array}{c}-0.003 \\
(0.000)^{* * *}\end{array}$ & $\begin{array}{c}-0.001 \\
(0.000)^{* * *}\end{array}$ & $\begin{array}{c}-0.003 \\
(0.000)^{* * *}\end{array}$ & $\begin{array}{c}-0.001 \\
(0.000)^{* * *}\end{array}$ & $\begin{array}{c}-0.004 \\
(0.001)^{* * *}\end{array}$ \\
\hline Female & $\begin{array}{c}-0.013 \\
(0.003)^{* * *}\end{array}$ & $\begin{array}{c}-0.025 \\
(0.009)^{* * *}\end{array}$ & $\begin{array}{c}-0.010 \\
(0.003)^{* * *}\end{array}$ & $\begin{array}{c}-0.011 \\
(0.006)^{*}\end{array}$ & $\begin{array}{l}-0.008 \\
(0.006)\end{array}$ & $\begin{array}{c}-0.019 \\
(0.010)^{*}\end{array}$ \\
\hline Large city & $\begin{array}{c}0.015 \\
(0.007)^{* *}\end{array}$ & $\begin{array}{c}0.026 \\
(0.010)^{* *}\end{array}$ & $\begin{array}{c}0.003 \\
(0.003)\end{array}$ & $\begin{array}{c}0.001 \\
(0.008)\end{array}$ & $\begin{array}{c}0.005 \\
(0.006)\end{array}$ & $\begin{array}{l}-0.000 \\
(0.010)\end{array}$ \\
\hline Healthy & $\begin{array}{c}-0.008 \\
(0.004)^{* *}\end{array}$ & $\begin{array}{c}-0.041 \\
(0.008)^{* * *}\end{array}$ & $\begin{array}{c}-0.008 \\
(0.005)^{*}\end{array}$ & $\begin{array}{c}-0.030 \\
(0.008)^{* * *}\end{array}$ & $\begin{array}{c}-0.028 \\
(0.011)^{* * *}\end{array}$ & $\begin{array}{c}-0.030 \\
(0.015)^{* *}\end{array}$ \\
\hline \# of children & $\begin{array}{c}0.001 \\
(0.001)^{* *}\end{array}$ & $\begin{array}{c}0.002 \\
(0.001)\end{array}$ & $\begin{array}{l}-0.000 \\
(0.001)\end{array}$ & $\begin{array}{c}-0.003 \\
(0.002)^{*}\end{array}$ & $\begin{array}{c}0.002 \\
(0.002)\end{array}$ & $\begin{array}{l}-0.005 \\
(0.004)\end{array}$ \\
\hline $\begin{array}{l}\text { Pseudo R2 } \\
N\end{array}$ & $\begin{array}{c}0.23 \\
16,282\end{array}$ & $\begin{array}{c}0.08 \\
21,555\end{array}$ & $\begin{array}{c}0.23 \\
21,632\end{array}$ & $\begin{array}{c}0.12 \\
29,341\end{array}$ & $\begin{array}{c}0.24 \\
5,922\end{array}$ & $\begin{array}{c}0.11 \\
8,590\end{array}$ \\
\hline Close networks (abroad) test & $* *$ & $*$ & $* * *$ & $* *$ & $* *$ & $* *$ \\
\hline Close networks (local) test & n.s. & n.s. & n.s. & $*$ & n.s. & n.s. \\
\hline
\end{tabular}

\section{Table 17: Intention to migrate and education levels, full results corresponding to Table 9 .}

Note: The table shows marginal effects of sample-weighted probit regressions, st. errors are clustered at country-level, all specifications include year and country fixed effects and additional control variables at region and country-level which are omitted from the table. The dependent variable is a dummy for the intention to migrate locally or internationally (see text for details). Low education is defined as up to eight years of basic schooling, medium education - 9 to 15 years of education (completed secondary education and up to three years of tertiary education), high education - above 15 years of education (completed four years of education beyond high school and/or received a four-year college degree. All specifications include 'wealth' and 'standard of living' and their squared values. 'Local amenities' and 'local security' capture satisfaction at the city/local level, while 'contentment with the country' and 'corruption' reflect individual's satisfaction with the country-level institutions/amenities, 'work' reflects satisfaction with the job, 'close networks' reflect social networks (local and abroad) of the individual, while 'broad networks' are proxied by log of the share of other individuals at the current location that would like to move locally and abroad. For further details and description of individual controls see Section 4 . All of the indexes are principal components capturing information from the underlying variables - see Appendix B for further details. 


\begin{tabular}{|c|c|c|c|c|}
\hline & \multicolumn{2}{|c|}{ Linear specifications } & \multicolumn{2}{|c|}{ Non-linear specifications } \\
\hline & \multicolumn{4}{|c|}{ Intention to migrate } \\
\hline & internationally & locally & internationally & locally \\
\hline Local amenities & $\begin{array}{c}-0.015 \\
(0.007)^{* *}\end{array}$ & $\begin{array}{c}-0.078 \\
(0.027)^{* * *}\end{array}$ & $\begin{array}{c}-0.015 \\
(0.007)^{* *}\end{array}$ & $\begin{array}{c}-0.077 \\
(0.027)^{* * *}\end{array}$ \\
\hline Local security & $\begin{array}{l}-0.012 \\
(0.017)\end{array}$ & $\begin{array}{c}-0.152 \\
(0.040)^{* * *}\end{array}$ & $\begin{array}{l}-0.013 \\
(0.017)\end{array}$ & $\begin{array}{c}-0.153 \\
(0.041)^{* * *}\end{array}$ \\
\hline Contentment with the country & $\begin{array}{l}-0.010 \\
(0.007)\end{array}$ & $\begin{array}{l}-0.018 \\
(0.038)\end{array}$ & $\begin{array}{l}-0.011 \\
(0.007)\end{array}$ & $\begin{array}{l}-0.018 \\
(0.038)\end{array}$ \\
\hline Corruption & $\begin{array}{l}-0.015 \\
(0.013)\end{array}$ & $\begin{array}{l}-0.005 \\
(0.032)\end{array}$ & $\begin{array}{l}-0.016 \\
(0.013)\end{array}$ & $\begin{array}{l}-0.006 \\
(0.032)\end{array}$ \\
\hline Close local networks & $\begin{array}{c}-0.020 \\
(0.008)^{* *}\end{array}$ & $\begin{array}{c}-0.098 \\
(0.028)^{* * *}\end{array}$ & $\begin{array}{c}-0.019 \\
(0.008)^{* *}\end{array}$ & $\begin{array}{c}-0.098 \\
(0.027)^{* * *}\end{array}$ \\
\hline Relatives live(d) abroad & $\begin{array}{c}0.019 \\
(0.006)^{* * *}\end{array}$ & $\begin{array}{c}0.019 \\
(0.013)\end{array}$ & $\begin{array}{c}0.019 \\
(0.005)^{* * *}\end{array}$ & $\begin{array}{c}0.019 \\
(0.013)\end{array}$ \\
\hline Work & $\begin{array}{c}0.008 \\
(0.006)\end{array}$ & $\begin{array}{l}-0.009 \\
(0.029)\end{array}$ & $\begin{array}{c}0.007 \\
(0.006)\end{array}$ & $\begin{array}{l}-0.009 \\
(0.029)\end{array}$ \\
\hline Wealth & $\begin{array}{c}0.007 \\
(0.030)\end{array}$ & $\begin{array}{c}-0.122 \\
(0.053)^{* *}\end{array}$ & $\begin{array}{c}0.012 \\
(0.032)\end{array}$ & $\begin{array}{c}-0.115 \\
(0.052)^{* *}\end{array}$ \\
\hline Standard of living & $\begin{array}{l}-0.032 \\
(0.024)\end{array}$ & $\begin{array}{c}0.003 \\
(0.062)\end{array}$ & $\begin{array}{l}-0.032 \\
(0.023)\end{array}$ & $\begin{array}{c}0.009 \\
(0.062)\end{array}$ \\
\hline Broad networks abroad & $\begin{array}{c}0.027 \\
(0.004)^{* * *}\end{array}$ & & $\begin{array}{c}0.027 \\
(0.004)^{* * *}\end{array}$ & \\
\hline Broad local networks & & $\begin{array}{c}0.207 \\
(0.016)^{* * *}\end{array}$ & & $\begin{array}{c}0.207 \\
(0.015)^{* * *}\end{array}$ \\
\hline Married & $\begin{array}{c}-0.012 \\
(0.006)^{* *}\end{array}$ & $\begin{array}{l}-0.002 \\
(0.018)\end{array}$ & $\begin{array}{c}-0.012 \\
(0.006)^{* *}\end{array}$ & $\begin{array}{l}-0.002 \\
(0.018)\end{array}$ \\
\hline Age & $\begin{array}{c}-0.001 \\
(0.000)^{* * *}\end{array}$ & $\begin{array}{c}-0.003 \\
(0.001)^{* * *}\end{array}$ & $\begin{array}{c}-0.001 \\
(0.000)^{* * *}\end{array}$ & $\begin{array}{c}-0.004 \\
(0.001)^{* * *}\end{array}$ \\
\hline Education (medium) & $\begin{array}{l}-0.001 \\
(0.006)\end{array}$ & $\begin{array}{l}-0.002 \\
(0.019)\end{array}$ & $\begin{array}{c}0.000 \\
(0.007)\end{array}$ & $\begin{array}{l}-0.003 \\
(0.019)\end{array}$ \\
\hline Education (high) & $\begin{array}{c}0.006 \\
(0.008)\end{array}$ & $\begin{array}{c}0.038 \\
(0.025)\end{array}$ & $\begin{array}{c}0.006 \\
(0.008)\end{array}$ & $\begin{array}{c}0.036 \\
(0.025)\end{array}$ \\
\hline Female & $\begin{array}{l}-0.005 \\
(0.004)\end{array}$ & $\begin{array}{l}-0.020 \\
(0.020)\end{array}$ & $\begin{array}{l}-0.005 \\
(0.004)\end{array}$ & $\begin{array}{l}-0.020 \\
(0.020)\end{array}$ \\
\hline Large city & $\begin{array}{c}0.003 \\
(0.006)\end{array}$ & $\begin{array}{c}0.020 \\
(0.014)\end{array}$ & $\begin{array}{c}0.002 \\
(0.005)\end{array}$ & $\begin{array}{c}0.020 \\
(0.014)\end{array}$ \\
\hline Healthy & $\begin{array}{l}-0.011 \\
(0.008)\end{array}$ & $\begin{array}{l}-0.028 \\
(0.021)\end{array}$ & $\begin{array}{l}-0.012 \\
(0.008)\end{array}$ & $\begin{array}{l}-0.028 \\
(0.021)\end{array}$ \\
\hline \# of children & $\begin{array}{c}0.003 \\
(0.002)\end{array}$ & $\begin{array}{l}-0.004 \\
(0.005)\end{array}$ & $\begin{array}{c}0.003 \\
(0.002)\end{array}$ & $\begin{array}{l}-0.004 \\
(0.005)\end{array}$ \\
\hline $\begin{array}{l}\text { Pseudo R2 } \\
N\end{array}$ & $\begin{array}{c}0.20 \\
3,130\end{array}$ & $\begin{array}{c}0.08 \\
3,846\end{array}$ & $\begin{array}{c}0.21 \\
3,130\end{array}$ & $\begin{array}{c}0.08 \\
3,846\end{array}$ \\
\hline
\end{tabular}

Table 18: Marginal effects with family abroad.

Note: The table shows marginal effects of sample-weighted probit regressions, st. errors are clustered at country-level, all specifications are based on year 2010 only and do not include country fixed effects, but include additional control variables at region and country-level which are omitted from the table. The dependent variable is a dummy for the intention to migrate locally or internationally (see text for details). The first two specifications include 'wealth' and 'standard of living' in a linear form, the last two specifications include these variables and their squared values. 'Local amenities' and 'local security' capture satisfaction at the city/local level, while 'contentment with the country' and 'corruption' reflect individual's satisfaction with the country-level institutions/amenities, 'work' reflects satisfaction with the job, 'close networks' reflect social networks (local and abroad) of the individual, while 'broad networks' are proxied by log of the share of other individuals at the current location that would like to move locally and abroad. For further details and description of individual controls see Section 4 . All of the indexes are principal components capturing information from the underlying variables - see Appendix B for further details. 


\section{B Appendix: principal component-based indexes}

The tables below present the eigenvalue and scoring coefficients for each index. Note that each index was rescaled to range from 0 to 1.

\section{B.1 Local amenities and local security}

Table 19: List of questions used.

\begin{tabular}{|c|c|}
\hline Label & Full question \\
\hline Satisfaction with the city/area & Are you satisfied or dissatisfied with the city or area where you live? \\
\hline Satisfaction with the public transportation system & $\begin{array}{l}\text { In the city or area where you live, are you satisfied or dissatisfied with } \\
\text { the public transportation systems? }\end{array}$ \\
\hline Satisfaction with the roads/highways & $\begin{array}{l}\text { In the city or area where you live, are you satisfied or dissatisfied with } \\
\text { the roads and highways? }\end{array}$ \\
\hline Satisfaction with the schools/education system & $\begin{array}{l}\text { In the city or area where you live, are you satisfied or dissatisfied with } \\
\text { the educational system or the schools? }\end{array}$ \\
\hline Satisfaction with the availability of healthcare & $\begin{array}{l}\text { In the city or area where you live, are you satisfied or dissatisfied with } \\
\text { the availability of quality healthcare? }\end{array}$ \\
\hline Satisfaction with the availability of housing & $\begin{array}{l}\text { In the city or area where you live, are you satisfied or dissatisfied with } \\
\text { the availability of good, affordable housing? }\end{array}$ \\
\hline Satisfaction with the beauty or physical setting & $\begin{array}{l}\text { In the city or area where you live, are you satisfied or dissatisfied with } \\
\text { the beauty or physical setting? }\end{array}$ \\
\hline Personal safety at night & $\begin{array}{l}\text { Do you feel safe walking alone at night in the city or area where you } \\
\text { live? }\end{array}$ \\
\hline
\end{tabular}

Table 20: The first three components.

\begin{tabular}{lccc}
\hline & Component 1 & Component 2 & Component 3 \\
\hline Proportion explained & 0.470 & 0.124 & 0.101 \\
Proportion explained (cumulative) & 0.470 & 0.594 & 0.695 \\
Eigenvalue & 3.761 & 0.991 & 0.806 \\
\hline
\end{tabular}

\begin{tabular}{lccc}
\hline Variable/response & Component 1 & Component 2 & Component 3 \\
\hline Satisfaction with the city/area & 0.35 & 0.24 & 0.07 \\
Satisfaction with the public transportation system & 0.37 & -0.43 & 0.29 \\
Satisfaction with the roads/highways & 0.38 & -0.39 & 0.27 \\
Satisfaction with the schools/education system & 0.39 & -0.17 & 0.00 \\
Satisfaction with the availability of healthcare & 0.40 & -0.06 & -0.18 \\
Satisfaction with the availability of housing & 0.35 & 0.21 & -0.50 \\
Satisfaction with the beauty or physical setting & 0.35 & 0.30 & -0.38 \\
Personal safety at night & 0.21 & 0.66 & 0.64 \\
\hline
\end{tabular}

Table 21: The first three eigenvectors.

Based on these results, the first principal component is labelled as 'local amenities' and the second component as 'local security'.

\section{B.2 Contentment with the country and country-level corruption}

Table 22: List of questions used. 


\begin{tabular}{ll}
\hline Label & \multicolumn{1}{c}{ Full question } \\
\hline Confidence in the military & In this country, do you have confidence in each of the following, or not? \\
Confidence in the judicial system/courts & How about the military? \\
& In this country, do you have confidence in each of the following, or not? \\
Confidence in the national government & How about judicial system and courts? \\
& In this country, do you have confidence in each of the following, or not? \\
How about national government?
\end{tabular}

Table 23: The first three components.

\begin{tabular}{lccc}
\hline & Component 1 & Component 2 & Component 3 \\
\hline Proportion explained & 0.514 & 0.164 & 0.116 \\
Proportion explained (cumulative) & 0.514 & 0.678 & 0.794 \\
Eigenvalue & 4.113 & 1.309 & 0.931 \\
\hline
\end{tabular}

\begin{tabular}{lccc}
\hline Variable/response & Component 1 & Component 2 & Component 3 \\
\hline Confidence in the military & 0.32 & -0.32 & -0.43 \\
Confidence in the judicial system/courts & 0.38 & -0.22 & -0.35 \\
Confidence in the national government & 0.43 & -0.21 & 0.06 \\
Confidence in the fair elections & 0.37 & -0.03 & -0.19 \\
Spread of corruption in business & 0.28 & 0.66 & -0.09 \\
Spread of corruption in government & 0.34 & 0.57 & -0.02 \\
Approval of country leadership's job performance & 0.38 & -0.16 & 0.39 \\
Change in the country's economic conditions & 0.29 & -0.11 & 0.70 \\
\hline
\end{tabular}

Table 24: The first three eigenvectors.

Based on these results, the first principal component is labelled as "contentment with the country' and the second component as 'corruption'.

\section{B.3 Work}

Table 25: List of questions used.

\begin{tabular}{ll}
\hline Label & \multicolumn{1}{c}{ Full question } \\
\hline Job opportunities & $\begin{array}{l}\text { In the city or area where you live, are you satisfied or dissatisfied with } \\
\text { the availability of good job opportunities? }\end{array}$ \\
Job satisfaction & $\begin{array}{l}\text { Are you satisfied or dissatisfied with your job or the work you do? (with } \\
\text { modifications - see text) } \\
\text { Employment }\end{array}$ \\
\hline
\end{tabular}

Table 26: The first three components.

\begin{tabular}{lccc}
\hline & Component 1 & Component 2 & Component 3 \\
\hline Proportion explained & 0.633 & 0.291 & 0.076 \\
Proportion explained (cumulative) & 0.633 & 0.924 & 1.000 \\
Eigenvalue & 1.899 & 0.874 & 0.227 \\
\hline
\end{tabular}

Based on these results, the first principal component is labelled as 'work'. 


\begin{tabular}{lccc}
\hline Variable/response & Component 1 & Component 2 & Component 3 \\
\hline Job opportunities & 0.38 & 0.91 & 0.19 \\
Job satisfaction & 0.67 & -0.13 & -0.73 \\
Employment & 0.63 & -0.40 & 0.66 \\
\hline
\end{tabular}

Table 27: The first three eigenvectors.

\section{B.4 Wealth and standard of living}

Table 28: List of questions used.

\begin{tabular}{|c|c|}
\hline Label & Full question \\
\hline Income quintile & Household income within country quintiles. \\
\hline Perception of present income & $\begin{array}{l}\text { Which one of these phrases comes closest to your own feelings about } \\
\text { your household income these days? }\end{array}$ \\
\hline Current standard of living & $\begin{array}{l}\text { Are you satisfied or dissatisfied with your standard of living, all the } \\
\text { things you can buy and do? }\end{array}$ \\
\hline Changes in standard of living & $\begin{array}{l}\text { Right now, do you feel your standard of living is getting better or getting } \\
\text { worse? }\end{array}$ \\
\hline Mobile phone at home & Does your home have a cellular phone? \\
\hline Television at home & Does your home have a television \\
\hline Internet access at home & Does your home have access to the Internet? \\
\hline Money for food & $\begin{array}{l}\text { Have there been times in the past } 12 \text { months when you did not have } \\
\text { enough money to buy food that you or your family needed? }\end{array}$ \\
\hline Money for shelter & $\begin{array}{l}\text { Have there been times in the past } 12 \text { months when you did not have } \\
\text { enough money to provide adequate shelter or housing for you and your } \\
\text { family? }\end{array}$ \\
\hline
\end{tabular}

Table 29: The first three components.

\begin{tabular}{lccc}
\hline & Component 1 & Component 2 & Component 3 \\
\hline Proportion explained & 0.440 & 0.154 & 0.117 \\
Proportion explained (cumulative) & 0.440 & 0.594 & 0.711 \\
Eigenvalue & 3.961 & 1.387 & 1.050 \\
\hline
\end{tabular}

\begin{tabular}{lccc}
\hline Variable/response & Component 1 & Component 2 & Component 3 \\
\hline Income quintile & 0.25 & 0.02 & 0.40 \\
Perception of present income & 0.36 & 0.20 & 0.17 \\
Current standard of living & 0.35 & 0.40 & 0.12 \\
Changes in standard of living & 0.22 & 0.57 & 0.29 \\
Mobile phone at home & 0.34 & -0.41 & 0.22 \\
Television at home & 0.37 & -0.38 & 0.04 \\
Internet access at home & 0.38 & -0.37 & 0.05 \\
Money for food & 0.39 & 0.10 & -0.45 \\
Money for shelter & 0.30 & 0.12 & -0.67 \\
\hline
\end{tabular}

Table 30: The first three eigenvectors.

Based on these results, the first principal component is labelled as 'wealth' and the second component as 'standard of living'.

\section{B.5 Close local networks}

Table 31: List of questions used.

\begin{tabular}{ll}
\hline Label & \multicolumn{1}{c}{ Full question } \\
\hline Opportunities to make friends & $\begin{array}{l}\text { In the city or area where you live, are you satisfied or dissatisfied with } \\
\text { the opportunities to meet people and make friends? } \\
\text { If you were in trouble, do you have relatives or friends you can count } \\
\text { on to help you whenever you need them, or not? }\end{array}$ \\
\hline
\end{tabular}


Table 32: The first two components.

\begin{tabular}{lcc}
\hline & Component 1 & Component 2 \\
\hline Proportion explained & 0.603 & 0.397 \\
Proportion explained (cumulative) & 0.603 & 1.000 \\
Eigenvalue & 1.206 & 0.794 \\
\hline
\end{tabular}

\begin{tabular}{lcc}
\hline Variable/response & Component 1 & Component 2 \\
\hline Opportunities to make friends & 0.71 & 0.71 \\
Help available (local and abroad) & 0.71 & -0.71 \\
\hline
\end{tabular}

Table 33: The first two eigenvectors.

Based on these results, the first principal component is labelled as 'close local networks'.

\section{Appendix: sample coverage}

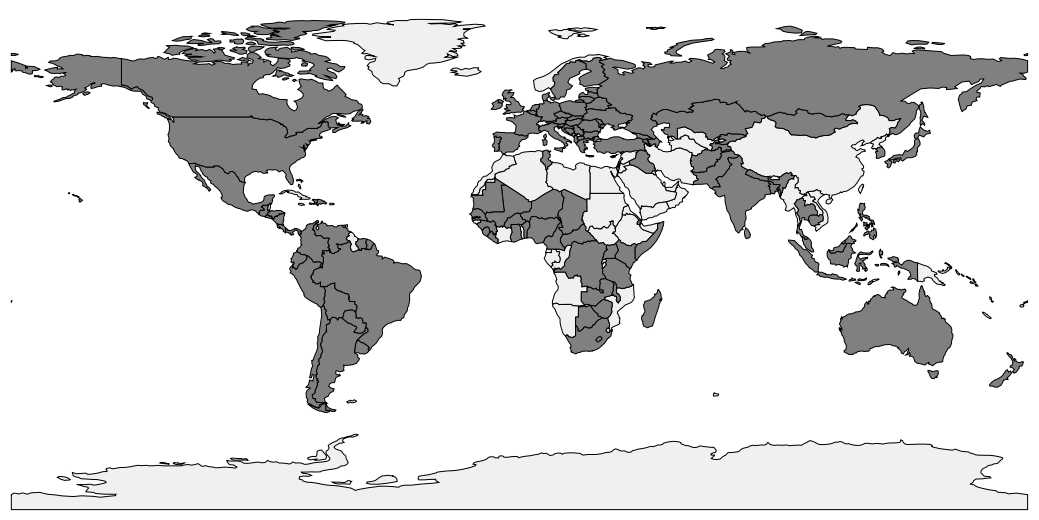

Figure 3: Geographic coverage of the sample used for estimation with the constructed indexes.

Note: Countries included in the estimations are shaded in dark colour, other countries are not included. For the number of observations by country see table 34. Source: own calculations using spmap. 


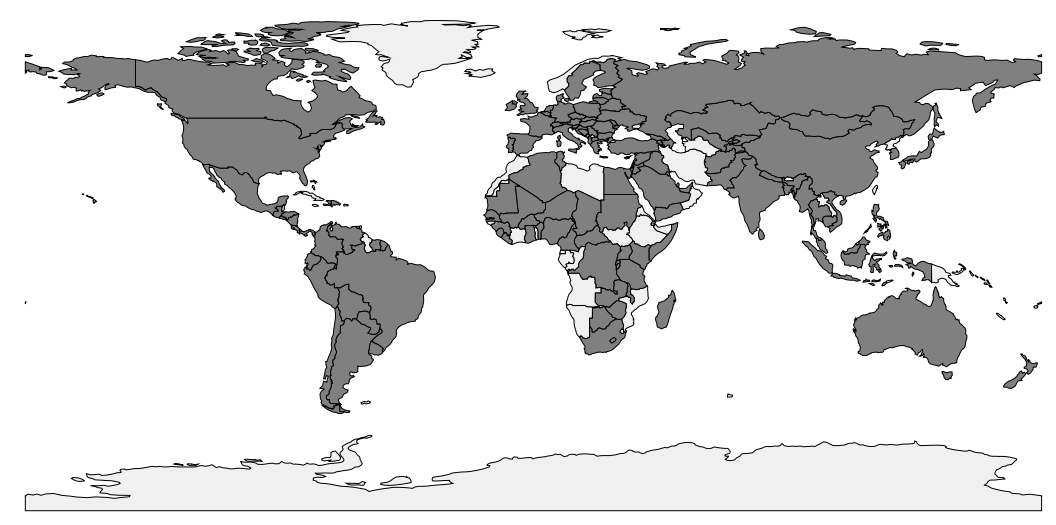

Figure 4: Geographic coverage of the sample with the single variables specification.

Note: Countries included in the estimations are shaded in dark colour, other countries are not included. For the number of observations by country see table 34 . Source: own calculations using spmap.

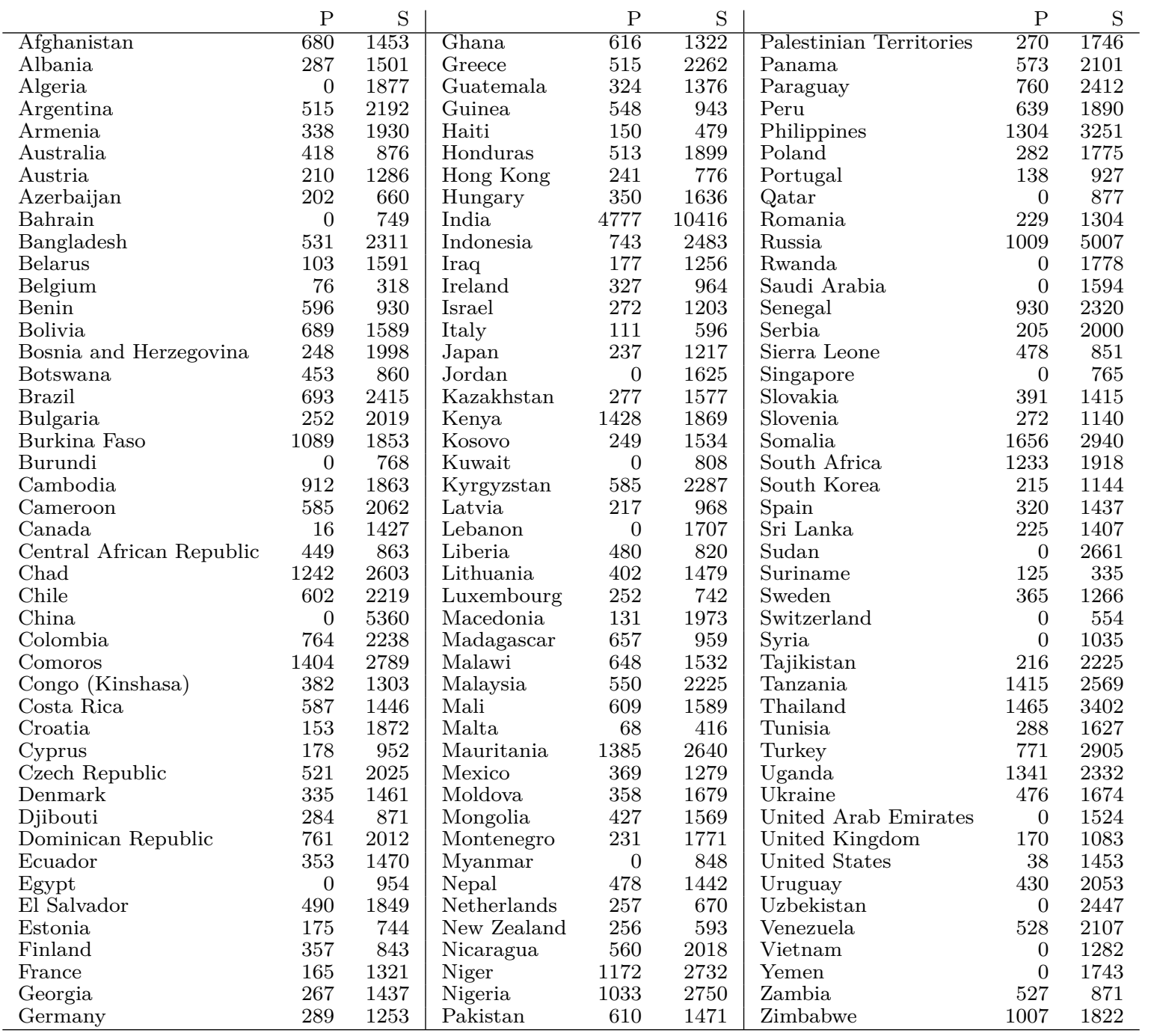

Table 34: List of countries and their sample size.

Note: numbers in column "P" represent sample size using principal component-based indexes, numbers in columns "S" represent sample size using single questions. Source: own calculations. 


\section{Appendix: descriptives by region}

\begin{tabular}{lcccc}
\hline & \multicolumn{2}{c}{ Close networks: } & \multicolumn{2}{c}{ Broad networks: } \\
& abroad & local & abroad & local \\
\hline European Union & 0.404 & 0.87 & 0.01 & 0.08 \\
Balkans & 0.347 & 0.74 & 0.02 & 0.05 \\
Europe-other & & 0.91 & & 0.09 \\
Commonwealth of Independent States & 0.281 & 0.76 & 0.01 & 0.06 \\
Australia-New Zealand & 0.622 & 0.93 & 0.02 & 0.14 \\
Southeast Asia & 0.205 & 0.84 & 0.00 & 0.08 \\
South Asia & 0.144 & 0.67 & 0.00 & 0.12 \\
East Asia & 0.186 & 0.81 & 0.00 & 0.10 \\
Latin America and the Caribbean & 0.415 & 0.83 & 0.02 & 0.16 \\
Northern America & 0.318 & 0.91 & 0.00 & 0.16 \\
Middle East and North Africa & 0.327 & 0.75 & 0.01 & 0.17 \\
Sub-Saharan Africa & 0.324 & 0.73 & 0.04 & 0.20 \\
Minimum value & 0.144 & 0.67 & 0.00 & 0.05 \\
Maximum value & 0.622 & 0.93 & 0.04 & 0.20 \\
\hline
\end{tabular}

Table 35: Average values for network variables

Note: Close networks measure whether the respondent has friends/family locally or abroad that can provide support. Broad networks measure the share of individuals in the same country as the respondent that expressed intention to migrate. Values for region "Europe-other" are missing due to lack of responses to the relevant questions in the sample for that region. Source: own calculations.

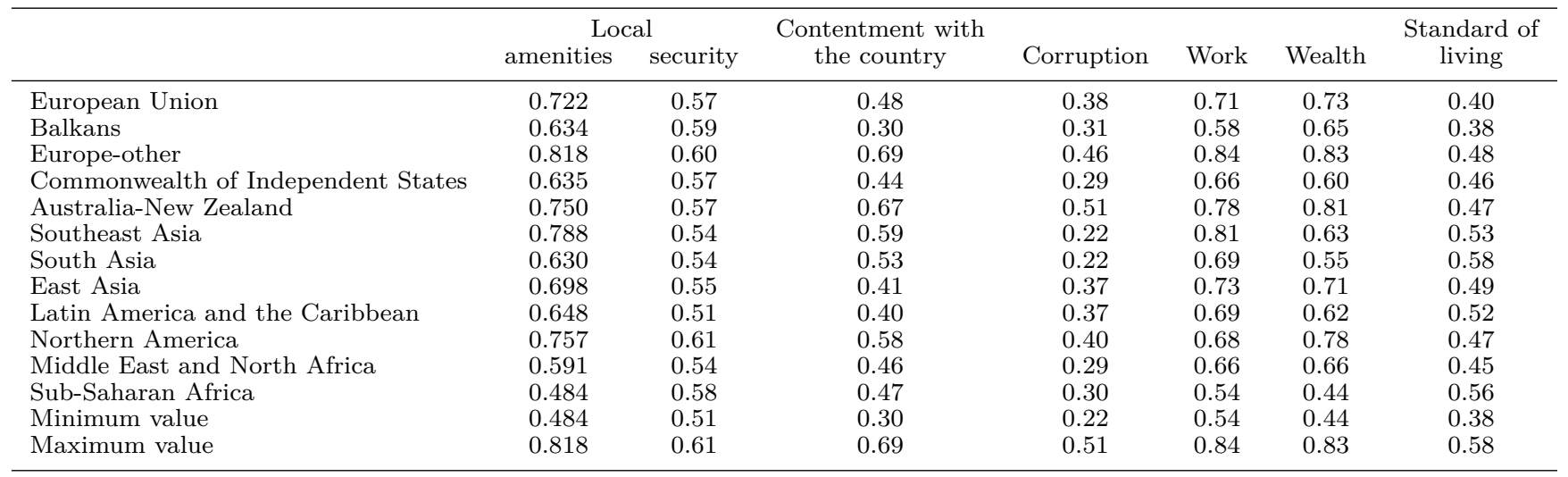

Table 36: Average values for selected variables

Note: description of the variables is provided in Appendix B. Source: own calculations.

\section{E Appendix: distinguishing between intentions to mi- grate locally and internationally}

World Poll survey contains several questions that can help distinguish between intention to migrate locally and internationally (and possibly distinguishing temporary and permanent moves, as well as comparing aspiration/desire with intention). The relevant questions are:

- WP85 - "In the next 12 months, are you likely or unlikely to move away from the city or area where you live?" 
- WP1325 - "Ideally, if you had the opportunity, would you like to move PERMANENTLY to another country, or would you prefer to continue living in this country?"

- WP10252 - "Are you planning to move permanently to another country in the next 12 months, or not?"28

- WP9455 - "Have you done any preparation for this move? (For example, applied for residency or visa, purchased the ticket, etc.)"29

- WP9498 - "Ideally, if you had the opportunity, would you like to go to another country for temporary work, or not?"

The answer to WP85 can help identify individuals that are likely to migrate - locally or internationally. Arguably, WP85 elicits firmer intentions than those elicited by questions WP1325 and WP9498 ("...are you likely to move..." vs. "ideally, if you had the opportunity, would you like to move..."). The closest phrasing is in question WP10252: similar time periods (next 12 months), relatively firm intention (there is no reference to ideal conditions or opportunities); and in question WP9455: similar time period and firm intention (steps already taken).

A rigorous interpretation of WP85 and WP10252/9455 would require many further clarifications to make them congruent. Firstly, WP85 does not contain indication of the length of the move (temporary vs. permanent), while WP10252 is specifically applicable to permanent migration. This means that for further comparison we need to assume that WP85 is interpreted for permanent moves. Secondly, it is possible that an individual will move locally before permanently migrating abroad. This means that separation between local and international migration will be based only on intended final destination in 12 months' time. Thirdly, in terms of firmness of intentions WP85 appears to be between WP10252, which is a bit weaker than WP85, and WP9455, which is a bit stronger than WP85. Since WP9455 is asked only given positive response to WP10252, the sample size will be larger if WP10252 is used for comparison with WP85. The procedure below can be modified to use WP9455 instead, if needed. Fourthly, there could be different interpretation of WP1325 by natives and current migrants. Current migrants might not think of returning home as a permanent move to another country. This issue will be ignored in the procedure below, but can be addressed to some extent by filtering out current migrants from the sample.

Assuming that individuals interpret questions WP85 and WP10252 in a similar way, it is possible to use these questions to distinguish between those that intend to move locally and internationally. The intended final destination in 12 months' time can be:

- Current location;

- Domestic location (local migration);

- Foreign location (international migration).

\footnotetext{
${ }^{28} \mathrm{WP} 10252$ is asked only for individuals that responded "Yes" to WP1325.

${ }^{29}$ WP9455 is asked only for individuals that responded "Yes" to WP10252.
} 


\begin{tabular}{|c|c|c|c|c|}
\hline $\begin{array}{l}\text { Are you } \\
\text { likely to } \\
\text { move }^{A} ?\end{array}$ & $\begin{array}{l}\text { Would you like to } \\
\text { move abroad }^{B} ?\end{array}$ & $\begin{array}{l}\text { Are you } \\
\text { planning to } \\
\text { move } \\
\text { abroad }^{C} ?\end{array}$ & Imputed status & Motivation \\
\hline \multirow[t]{3}{*}{$\begin{array}{l}\text { Likely to } \\
\text { move }\end{array}$} & $\begin{array}{l}\text { Like to continue living } \\
\text { in this country }\end{array}$ & $\begin{array}{l}\text { The question } \\
\text { is not asked. }\end{array}$ & $\begin{array}{l}\text { Intention to } \\
\text { migrate locally }\end{array}$ & $\begin{array}{l}\text { Likely to move locally, because there is no ex- } \\
\text { pression of a desire to move abroad. }\end{array}$ \\
\hline & $\begin{array}{l}\text { Like to move to } \\
\text { another country }\end{array}$ & No & $\begin{array}{l}\text { Dreamer (moving } \\
\text { locally) }\end{array}$ & $\begin{array}{l}\text { Likely to move locally, since the move abroad } \\
\text { will be taken only under ideal conditions. }\end{array}$ \\
\hline & & $\begin{array}{l}\text { Yes, will } \\
\text { move in next } \\
12 \text { months }\end{array}$ & $\begin{array}{l}\text { Intention to } \\
\text { migrate } \\
\text { internationally }\end{array}$ & $\begin{array}{l}\text { Likely to move internationally, since indicated } \\
\text { move (WP85) and took steps for moving to a } \\
\text { foreign location. }\end{array}$ \\
\hline \multirow[t]{3}{*}{$\begin{array}{l}\text { Not likely to } \\
\text { move }\end{array}$} & $\begin{array}{l}\text { Like to continue living } \\
\text { in this country }\end{array}$ & $\begin{array}{l}\text { The question } \\
\text { is not asked. }\end{array}$ & Intention to stay & Not likely to move. \\
\hline & $\begin{array}{l}\text { Like to move to } \\
\text { another country }\end{array}$ & No & Dreamer & $\begin{array}{l}\text { Would like to move away, but no intention to } \\
\text { do so in the near future. }\end{array}$ \\
\hline & & $\begin{array}{l}\text { Yes, will } \\
\text { move in the } \\
\text { next } 12 \\
\text { months }\end{array}$ & $\begin{array}{l}\text { Contradictory } \\
\text { response }\end{array}$ & $\begin{array}{l}\text { The response to WP } 85 \text { contradicts answer to } \\
\text { WP } 10252 \text {. Can treat these responses as either } \\
\text { stayers or international migrants, or alterna- } \\
\text { tively can discard these observations (the last } \\
\text { option is used for this paper). }\end{array}$ \\
\hline
\end{tabular}

Table 37: Identifying intentions to migrate locally and internationally - motivation.

Notes:

${ }^{A}$ Full question: "In the next 12 months, are you likely or unlikely to move away from the city or area where you live?"

${ }^{B}$ Full question: "Ideally, if you had the opportunity, would you like to move PERMANENTLY to another country, or would you prefer to continue living in this country?"

${ }^{C}$ Full question: "Are you planning to move permanently to another country in the next 12 months, or not? (asked only of those who would like to move to another country)"

\begin{tabular}{rcc}
\hline Label & Total & $\begin{array}{c}\text { As \% of valid } \\
\text { observations }\end{array}$ \\
\hline Intention to stay at the current location & $367^{\prime} 957$ & 85.2 \\
Intention to migrate locally & $57^{\prime} 407$ & 13.3 \\
Intention to migrate internationally & $6^{\prime} 472$ & 1.5 \\
\hline Valid observations & $431^{\prime} 836$ & 100 \\
\hline
\end{tabular}

Table 38: Identifying intentions to migrate locally and internationally - summary numbers.

As a starting point, only respondents that gave clear "Yes" and "No" responses are considered. Later, this can be generalized to include other responses. Table 37 summarizes possible combinations and separates individuals into three categories, depending on their intention to stay, migrate locally or internationally. The number of observations in each category is presented in Table 38 . 


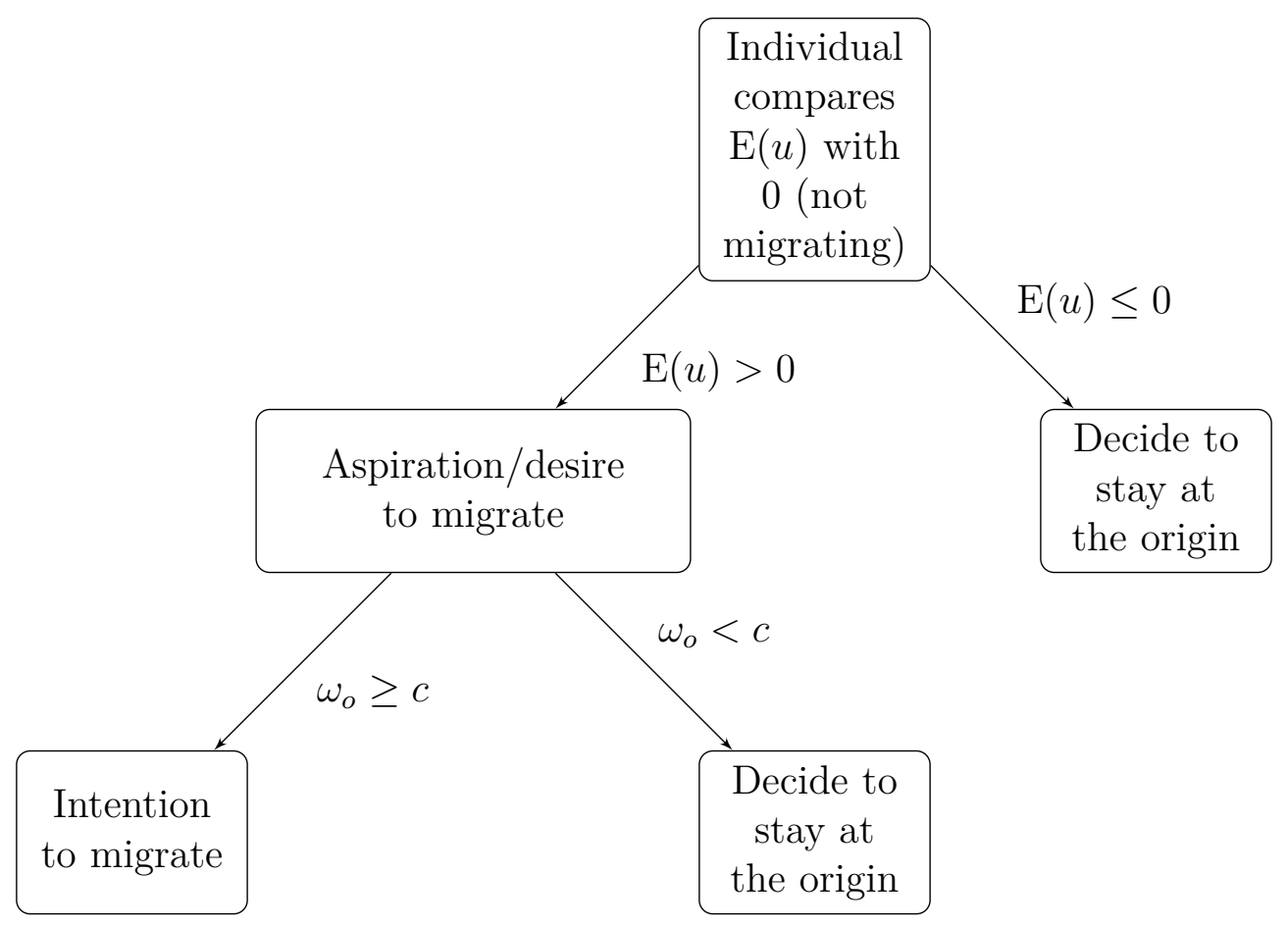

Figure 5: Decision tree for the individual - aspiration/desire vs. intention. 